\title{
VALORAÇÃO ECONÔMICA \\ AMBIENTAL DE ÁREA PROTEGIDA EM CAMPINA GRANDE-PB
}

AUGUSTO CÉSAR TRIGUEIRO FÉLIX ISABEL LAUSANNE FONTGALLAND

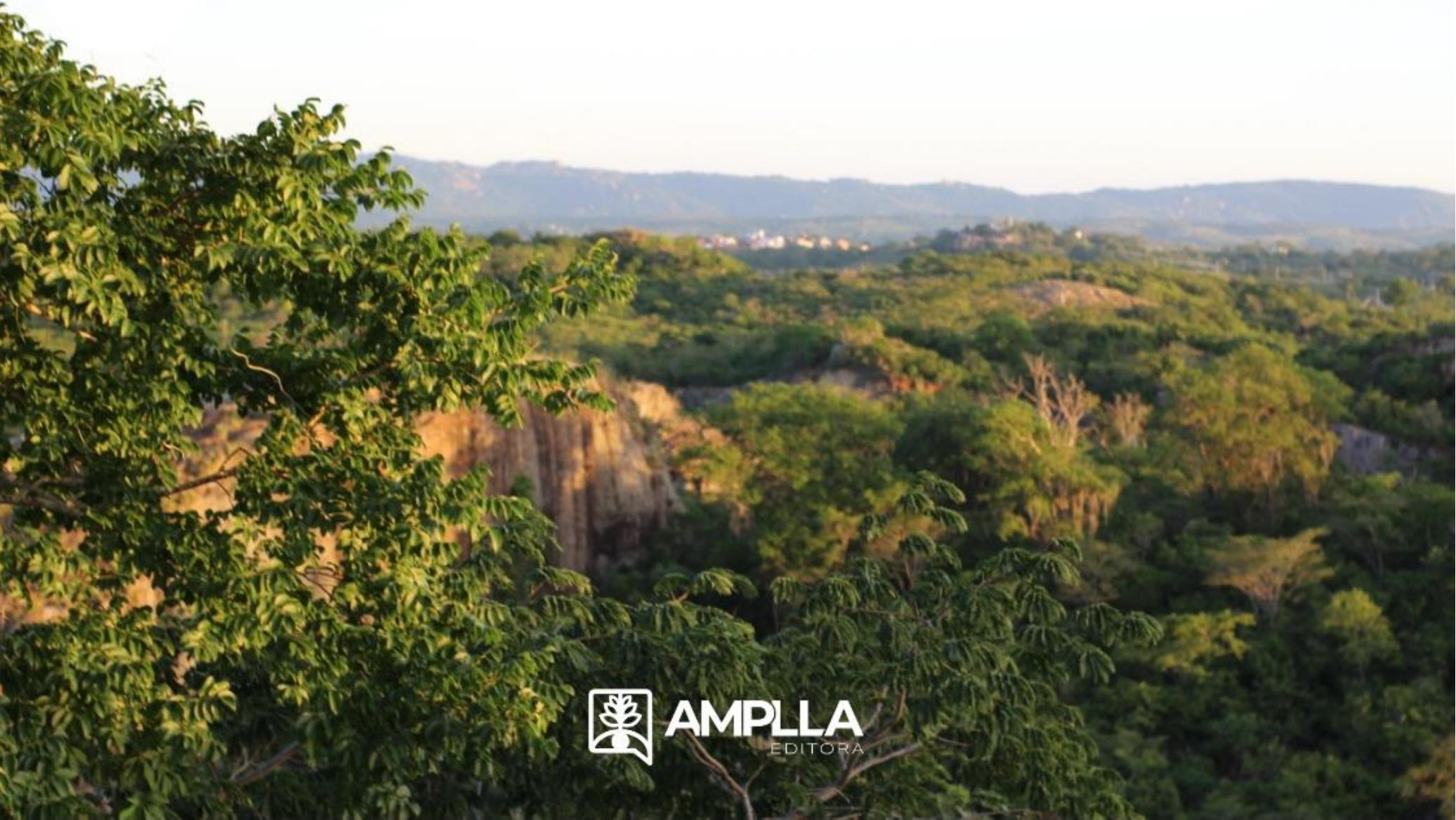




\section{VALORAÇÃO ECONÔMICA}

\section{AMBIENTAL DE ÁREA PROTEGIDA EM CAMPINA GRANDE-PB}

\section{AUGUSTO CÉSAR TRIGUEIRO FÉLIX \\ ISABEL LAUSANNE FONTGALLAND}

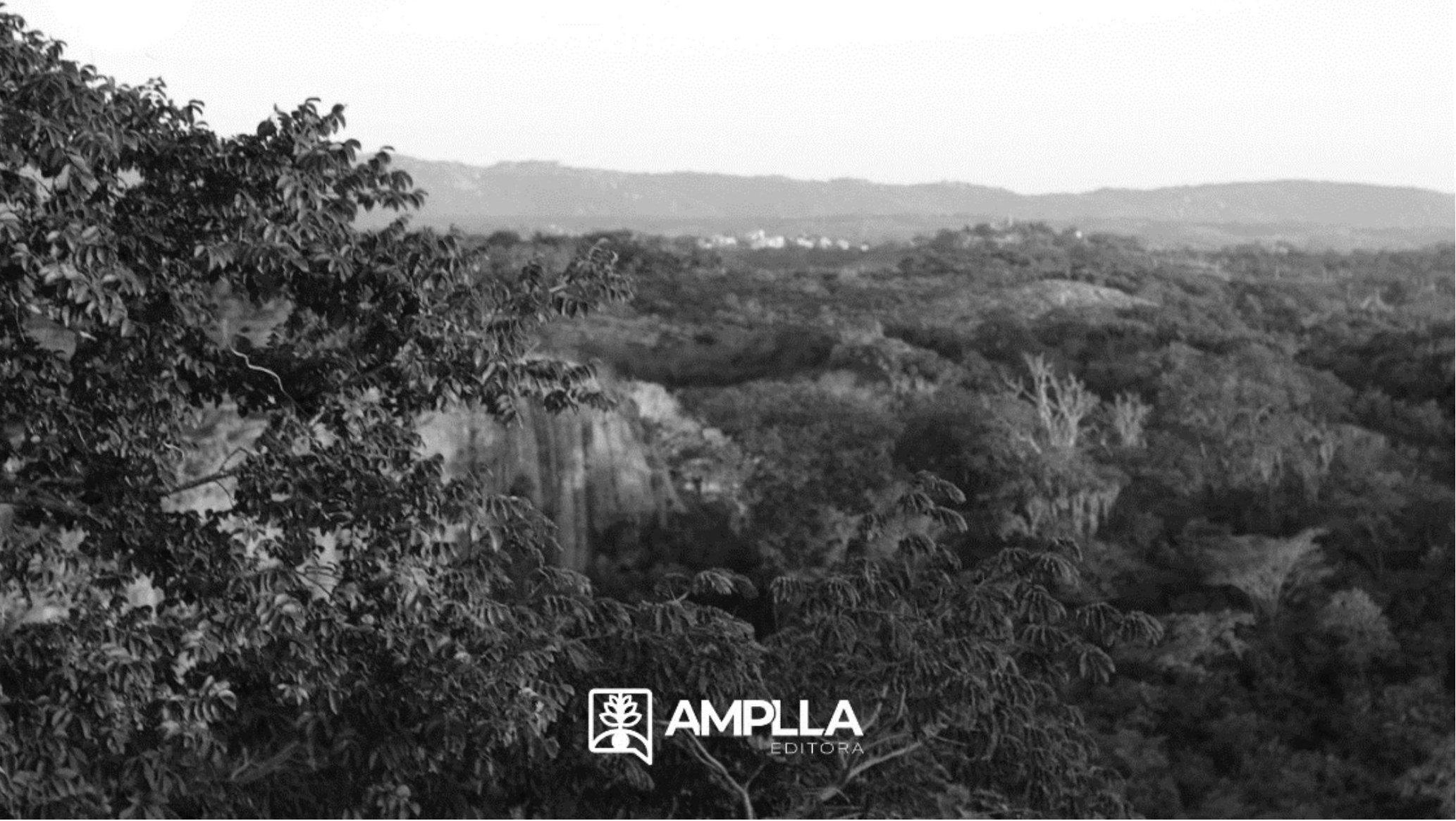




\section{递 AMPLLA}

2021 - Editora Amplla

Copyright da Edição @ Editora Amplla

Copyright do Texto $(\mathcal{C})$ Os autores

Editor Chefe: Leonardo Pereira Tavares

Design da Capa: Editora Amplla

Diagramação: Higor Costa de Brito

Revisão: Os autores

Valoração econômica ambiental de área protegida em Campina Grande-PB está licenciado sob CC BY 4.0.

Esta licença exige que as reutilizações deem crédito aos criadores. Ele permite que qualquer meio ou formato, mesmo para fins comerciais.

O conteúdo da obra e seus dados em sua forma, correção e confiabilidade são de responsabilidade exclusiva dos autores, não representando a posição oficial da Editora Amplla. É permitido o download da obra e o compartilhamento desde que sejam atribuídos créditos aos autores. Todos os direitos para esta edição foram cedidos à Editora Amplla.

ISBN: 978-65-88332-80-1

DOI: $10.51859 /$ amplla.vea801.1121-0

Editora Amplla

Campina Grande - PB - Brasil contato@ampllaeditora.com.br www.ampllaeditora.com.br 


\section{CONSELHO EDITORIAL}

Andréa Cátia Leal Badaró - Universidade Tecnológica Federal do Paraná

Andréia Monique Lermen - Universidade Federal do Rio Grande do Sul

Antoniele Silvana de Melo Souza Universidade Estadual do Ceará

Aryane de Azevedo Pinheiro - Universidade Federal do Ceará

Bergson Rodrigo Siqueira de Melo Universidade Estadual do Ceará

Bruna Beatriz da Rocha - Instituto Federal do Sudeste de Minas Gerais

Bruno Ferreira - Universidade Federal da Bahia

Caio César Costa Santos - Universidade Federal de Sergipe

Carina Alexandra Rondini - Universidade Estadual Paulista

Carla Caroline Alves Carvalho - Universidade Federal de Campina Grande

Carlos Augusto Trojaner - Prefeitura de Venâncio Aires

Carolina Carbonell Demori - Universidade Federal de Pelotas

Cícero Batista do Nascimento Filho Universidade Federal do Ceará

Clécio Danilo Dias da Silva - Universidade Federal do Rio Grande do Norte

Daniela de Freitas Lima - Universidade Federal de Campina Grande

Darlei Gutierrez Dantas Bernardo Oliveira Universidade Estadual da Paraíba

Denise Barguil Nepomuceno - Universidade Federal de Minas Gerais

Dylan Ávila Alves - Instituto Federal Goiano

Edson Lourenço da Silva - Instituto Federal de Educação, Ciência e Tecnologia do Piauí

Elane da Silva Barbosa - Universidade Estadual do Ceará

Érica Rios de Carvalho - Universidade Católica do Salvador

Gabriel Gomes de Oliveira - Universidade Estadual de Campinas

Gilberto de Melo Junior - Instituto Federal do Pará

Givanildo de Oliveira Santos - Instituto Brasileiro de Educação e Cultura

Higor Costa de Brito - Universidade Federal de Campina Grande

Isane Vera Karsburg - Universidade do Estado de Mato Grosso

Israel Gondres Torné - Universidade do Estado do Amazonas

Italan Carneiro Bezerra - Instituto Federal da Paraíba
Ivo Batista Conde - Universidade Estadual do Ceará

Jaqueline Rocha Borges dos Santos Universidade Federal Rural do Rio de Janeiro Jessica Wanderley Souza do Nascimento Instituto de Especialização do Amazonas João Henriques de Sousa Júnior Universidade Federal de Santa Catarina João Manoel Da Silva - Universidade Federal de Alagoas

João Vitor Andrade - Universidade de São Paulo

Joilson Silva de Sousa - Instituto Federal do Rio Grande do Norte

José Cândido Rodrigues Neto - Universidade Estadual da Paraíba

Jose Henrique de Lacerda Furtado - Instituto Federal do Rio de Janeiro

Josenita Luiz da Silva - Faculdade Frassinetti do Recife

Josiney Farias de Araújo - Universidade Federal do Pará

Karina de Araújo Dias - SME/Prefeitura Municipal de Florianópolis

Katia Fernanda Alves Moreira - Universidade Federal de Rondônia

Laíze Lantyer Luz - Universidade Católica do Salvador

Lindon Johnson Pontes Portela Universidade Federal do Oeste do Pará

Lucas Araújo Ferreira - Universidade Federal do Pará

Lucas Capita Quarto - Universidade Federal do Oeste do Pará

Lúcia Magnólia Albuquerque Soares de Camargo - Unifacisa Centro Universitário

Luciana de Jesus Botelho Sodré dos Santos Universidade Estadual do Maranhão

Luís Paulo Souza e Souza - Universidade Federal do Amazonas

Luiza Catarina Sobreira de Souza - Faculdade de Ciências Humanas do Sertão Central

Manoel Mariano Neto da Silva - Universidade Federal de Campina Grande

Marcelo Alves Pereira Eufrasio - Centro Universitário Unifacisa

Marcelo Williams Oliveira de Souza Universidade Federal do Pará

Marcos Pereira dos Santos - Faculdade Rachel de Queiroz

Marcus Vinicius Peralva Santos Universidade Federal da Bahia

Marina Magalhães de Morais - Universidade Federal de Campina Grande

Michele Antunes - Universidade Feevale 
Milena Roberta Freire da Silva - Universidade Federal de Pernambuco

Nadja Maria Mourão - Universidade do Estado de Minas Gerais

Natan Galves Santana - Universidade Paranaense

Nathalia Bezerra da Silva Ferreira Universidade do Estado do Rio Grande do Norte

Neide Kazue Sakugawa Shinohara Universidade Federal Rural de Pernambuco Neudson Johnson Martinho - Faculdade de Medicina da Universidade Federal de Mato Grosso

Patrícia Appelt - Universidade Tecnológica Federal do Paraná

Paula Milena Melo Casais - Universidade Federal da Bahia

Paulo Henrique Matos de Jesus - Universidade Federal do Maranhão

Rafael Rodrigues Gomides - Faculdade de Quatro Marcos

Reângela Cíntia Rodrigues de Oliveira Lima Universidade Federal do Ceará

Rebeca Freitas Ivanicska - Universidade Federal de Lavras

Renan Gustavo Pacheco Soares - Autarquia do Ensino Superior de Garanhuns

Renan Monteiro do Nascimento Universidade de Brasília

Ricardo Leoni Gonçalves Bastos Universidade Federal do Ceará

Rodrigo da Rosa Pereira - Universidade Federal do Rio Grande
Sabrynna Brito Oliveira - Universidade Federal de Minas Gerais

Samuel Miranda Mattos - Universidade Estadual do Ceará

Shirley Santos Nascimento - Universidade Estadual Do Sudoeste Da Bahia

Silvana Carloto Andres - Universidade Federal de Santa Maria

Silvio de Almeida Junior - Universidade de Franca

Tatiana Paschoalette Rodrigues Bachur Universidade Estadual do Ceará

Telma Regina Stroparo - Universidade Estadual do Centro-Oeste

Thayla Amorim Santino - Universidade Federal do Rio Grande do Norte

Virgínia Maia de Araújo Oliveira - Instituto Federal da Paraíba

Virginia Tomaz Machado - Faculdade Santa Maria de Cajazeiras

Walmir Fernandes Pereira - Miami University of Science and Technology

Wanessa Dunga de Assis - Universidade Federal de Campina Grande

Wellington Alves Silva - Universidade Estadual de Roraima

Yáscara Maia Araújo de Brito - Universidade Federal de Campina Grande

Yasmin da Silva Santos - Fundação Oswaldo Cruz

Yuciara Barbosa Costa Ferreira Universidade Federal de Campina Grande 


\section{AMPLLA}

2021 - Editora Amplla

Copyright da Edição @ Editora Amplla

Copyright do Texto $(\mathcal{C})$ Os autores

Editor Chefe: Leonardo Pereira Tavares

Design da Capa: Editora Amplla

Diagramação: Higor Costa de Brito

Revisão: Os autores

Dados Internacionais de Catalogação na Publicação (CIP)

Félix, Augusto César Trigueiro

Valoração econômica ambiental de área protegida em Campina Grande-PB [livro eletrônico] / Augusto César Trigueiro Félix, Isabel Lausanne Fontgalland. -Campina Grande : Editora Amplla, 2021.

$88 \mathrm{p}$.

Formato: $\mathrm{PDF}$

ISBN : $978-65-88332-80-1$

1. Áreas protegidas - Parques. 2. Proteção ambiental - Aspectos econômicos. 3. Mercado imobiliário. I. Fontgalland, Isabel Lausanne. II. Título.

Sueli Costa - Bibliotecária - CRB-8/5213

(SC Assessoria Editorial, SP, Brasil)

Índices para catálogo sistemático:

1. Áreas naturais protegidas : Estudo de valoração econômica 333.72

Editora Amplla

Campina Grande - PB - Brasil contato@ampllaeditora.com.br www.ampllaeditora.com.br

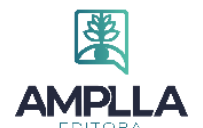




\section{AGRADECIMENTOS}

As noites em claro e as discussões que tivemos, foram recompensadas quando vimos a finalização dessa obra tão singular. Acreditar no que fizemos, foi o passo decisivo nesta publicação. Começamos de um ponto, em que muitos confundiam o conceito de valoração com o conceito de valorização. Acreditamos em Nordhaus e em Munasinghe e de lá tivemos ciência de que tudo o que escrevíamos tinha tudo a ver.

Em primeiro lugar, os agradecimentos vão para os mestres ambientalistas que ecoaram suas vozes para salvar o planeta e as pessoas. A vida nunca foi tão bem representada por eles. Assim, estendemos o tapete vermelho para Rachel Carson e Garret Hardin que não por acaso deixaram as suas marcas na ciência, como nós ambicionamos deixar as nossas. Esses dois, cientistas ambientalistas, mudaram as nossas vidas e nos fizeram compreender o que era incompreensível: "ter vidas que morrem em nossas mãos...o planeta que morre em nossas mãos".

Os agradecimentos abaixo, não menos importantes refletem o desenrolar da nossa escrita e sem eles não haveria lugar para essa obra:

Ao Programa de Pós-Graduação em Engenharia e Gestão de Recursos Naturais (PPGERN), e a Universidade Federal de Campina Grande (UFCG) pelo espaço nesta discussão inicial.

À Coordenação de Aperfeiçoamento Pessoal de Nível Superior - CAPESpelo auxílio financeiro que possibilitou esses anos de dedicação à pesquisa acadêmica.

Ao escritório de Avaliações e Perícias em Engenharia PROXY Engenharia LTDA, na figura do responsável técnico Eng. Paulo Félix da Silva, que de bom grado cedeu os dados imobiliários usados na pesquisa.

Ao Instituto Brasileiro de Geografia e Estatística - João Pessoa

Às nossas famílias, que em meio a uma pandemia que parece nos dividir nos uniu mais e mais. Neles, estão todas as nossas certezas e esperanças que o fazemos e cremos tem a primeira guarida. 
"O estudante prudente, ouve todos com prazer, lê tudo, não despreza escrito algum, pessoa alguma, doutrina alguma." 


\section{RESUMO}

As áreas protegidas são um importante meio para a conservação dos sistemas ambientais. Elas são usadas com esta finalidade desde o século XIX, mas só no século $X X$ é que ficaram famosas, devido principalmente a influência de organizações internacionais como a União Internacional pela Conservação da Natureza (IUCN), que até hoje apresenta-se como uma das principais organizações em defesa da proteção ambiental. No Brasil, as unidades de conservação se popularizaram a partir da criação do Sistema Nacional de Unidades de Conservação (SNUC), chegando a um aumento exponencial na criação dessas áreas. Todavia, o aumento da criação destas áreas não garantiu que os sistemas ecológicos fossem efetivamente protegidos, muito devido as dificuldades de recursos financeiros para este fim. Neste sentido, o objeto de estudo em questão, o parque do poeta, insere-se nesta discussão. Partindo de um aporte teórico econômico para interpretação deste fenômeno, o trabalho propôs a responder a seguinte questão: qual é o benefício da conservação da área protegida, conhecida por Parque Estadual do Poeta e Repentista Juvenal de Oliveira, apreendido pelo mercado imobiliário em Campina Grande - PB? Para se tirar qualquer posicionamento destes questionamentos tem-se por objetivo geral: analisar os benefícios, em termos marginais, proporcionados pela qualidade ambiental oferecida pelo Parque do Poeta, e por objetivos específicos: estimar o modelo de preços hedônicos do mercado imobiliário em Campina Grande- PB; mensurar o efeito que a qualidade ambiental produzida pelo Parque do Poeta tem no mercado imobiliário e analisar as políticas de proteção das áreas protegidas à luz da teoria econômica ambiental. Os resultados da pesquisa mostram que este efeito acontece no mercado imobiliário de Campina Grande, ele é observado no valor do parâmetro calculado do modelo estatístico através da metodologia de preços hedônicos. 0 valor econômico ambiental da área protegida foi entendido como a derivada primeira da função de preços hedônicos com relação a proximidade de apartamentos na cidade com a área protegida e a partir dela pode-se constatar que a variação da disposição a pagar por um ambiente natural em Campina Grande é maior quando o imóvel se aproxima do Parque do Poeta.

Palavras-chave: bens ambientais, preços hedônicos, mercado imobiliário. 


\section{ABSTRACT}

Protected areas are an important means for the conservation of environmental systems. They have been used for this purpose since the 19th century, but only in the 20th century did they become famous, mainly due to the influence of international organizations such as the IUCN, which to this day is one of the main organizations in defense of environmental protection. In Brazil, conservation units became popular after the creation of the National System of Conservation Units, with an exponential increase in the creation of these areas. The increase in the number of these areas has not ensured that ecological systems are actually protected. In this sense, the object of the study in question, the poet's park, was inserted into this discussion. Starting from an economic theoretical contribution for the interpretation of this phenomenon, the work proposed to answer the following question: what is the benefit of the conservation of the protected area that is seized by the real estate market, known as Parque Estadual do Poeta e Repentista Juvenal de Oliveira in Campina Grande - PB? Having as general objective: to evaluate the economic benefits provided by the conservation of the Parque Estadual do Poeta e Repentista Juvenal de Oliveira. And by specific objectives: to estimate the hedonic price model of the real estate market in Campina Grande- PB; to measure the effects that the existence of the protected area causes in the real estate market; and to analyze the protected area protection policies in the light of the environmental economic theory. The results of the research show that this effect happens in the real estate market of Campina Grande, it is observed in the parameter value calculated from the statistical model through the hedonic pricing methodology. The economic value of the protected area was understood as the marginal benefit of the proximity of the apartments to the protected area and from this it can be seen that the variation of willingness to pay for a natural environment in Campina Grande is greater when the property is closer to the Parque do Poeta.

Keywords: environmental goods, hedonic pricing, real estate market. 


\section{LISTA DE FIGURAS}

FIGURA 1- FLUXOGRAMA DO SISTEMA ECONÔMICO E SUA RELAÇ̃̃O COM O MEIO AMBIENTE.

FIGURA 2- GRÁFICOS DE CUSTOS MARGINAIS E BENEFÍCIOS MARGINAIS PARA EXTERNALIDADE NEGATIVA....................... 35

FIGURA 3- GRÁFICOS DE CUSTOS MARGINAIS E BENEFÍCIOS MARGINAIS PARA EXTERNALIDADE POSITIVA.

FIGURA 4 - DADOS DE APARTAMENTOS GEOLOCALIZADOS NO MUNICÍPIO DE CAMPINA GRANDE -PB. 60

FIGURA 5- DESCRIÇÃO DAS PARTES DE UM BOXPLOT. 62

FIGURA 6- GRÁFICO BOXPLOT PARA VALOR DO IMÓVEL POR BAIRROS DE CAMPINA GRANDE-PB. 62

FIGURA 7- MATRIZ DE CORRELAÇÕES .65

FIGURA 8- DIAGRAMAS DE DISPERSÃO. 65

FIGURA 9- GRÁFICO DOS RESÍDUOS PADRONIZADOS VERSUS VALORES AJUSTADOS DO MODELO 1. 69

FIGURA 10- GRÁFICO NORMAL Q-Q PLOT DO MODELO 1.. 70

FIGURA 11- GRÁFICO DOS RESÍDUOS PADRONIZADOS VERSUS VALORES AJUSTADOS DO MODELO 2. . .73

FIGURA 12- GRÁFICO NORMAL Q-Q PLOT DO MODELO 1. .74

FIGURA 13- GRÁFICO DE VALOR VERSUS DISTÂNCIA À ÁREA PROTEGIDA. . .75

FIGURA 14- DISPOSIÇÃO MARGINAL A PAGAR VERSUS DISTÂNCIA À ÁREA PROTEGIDA. .76 


\section{LISTA DE TABELAS}

TABELA 1 - CLASSIFICAÇÃO DOS SERVIÇOS AMBIENTAIS EM SERVIÇOS DE PROVISÃO, REGULAÇÃO, CULTURAIS E DE SUPORTE.

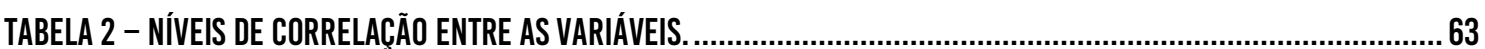

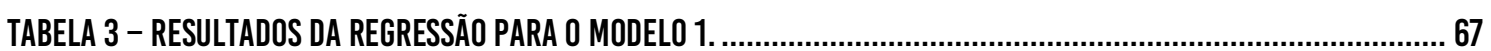

TABELA 4- RESULTADOS DA REGRESSÃO PARA O MODELO 2.

TABELA 5 - RESULTADOS DA REGRESSÃO PARA O MODELO 3 ...................................................................

\section{LISTA DE EQUAÇ̃̃ES}

EQUAÇÃO 1




\section{SUMÁRIO}

INTRODUÇÃO 13

CAPÍTULO I - ESTADO DA ARTE DAS ÁREAS PROTEGIDAS ............................................................. 19

1.1. ÁREAS PROTEGIDAS NO CONTEXTO INTERNACIONAL_.............................................. 19

1.2. ÁREAS PROTEGIDAS NO CONTEXTO BRASILEIRO .....................................................23

1.3. ÁREAS PROTEGIDAS E O DESENVOLVIMENTO ECONÔMICO ………..................................30

CAPÍTULO II - TEORIA ECONÔMICA E O MEIO AMBIENTE............................................................................ 32

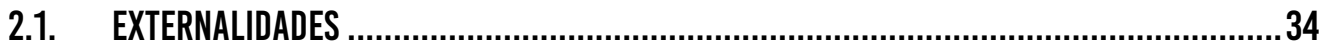

2.2. BENS PÚBLICOS ........................................................................................ 38

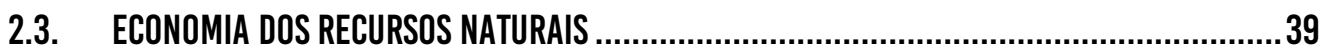

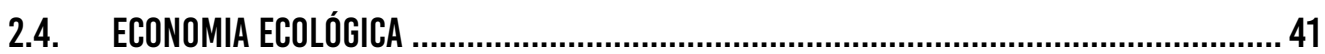

CAPÍTULO III - VALOR ECONÔMICO DE BENS E SERVIÇOS AMBIENTAIS .........................................................4

CAPÍTULO IV - METODOLOGIA..............................................................................................

4.1. MODELO DE PREÇOS HEDÔNICOS ......................................................................50

4.2. DESCRIÇÃO METODOLÓGICA ...........................................................................56

CAPÍTULO V - RESULTADOS E ANÁLISES .....................................................................................60

5.1. ANÁLISE EXPLORATÓRIA DOS DADOS .................................................................... 61

5.1.1. GRÁFICO BOXPLOT_................................................................................

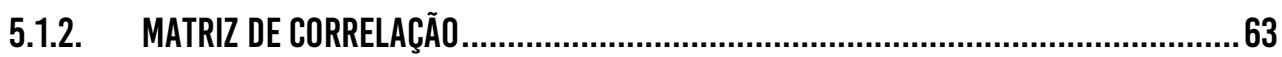

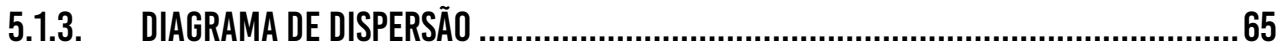

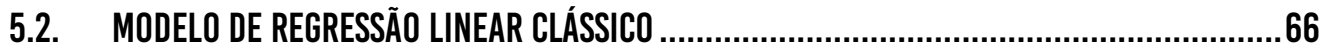

5.3. DISCUSSÃO DOS RESULTADOS .......................................................................

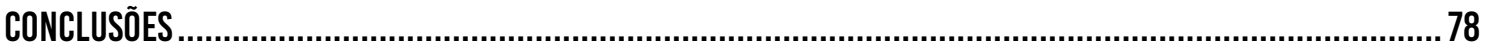

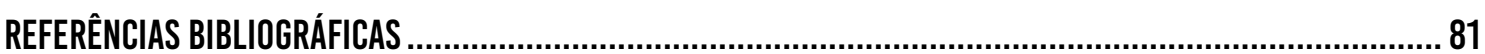




\section{INTRODUÇÃO}

Quando o termo economia é evocado, a ideia imediata é que se reporta a redução de gastos ou pensa-se em variados índices que são mostrados nos telejornais. Isto não acontece da mesma forma com o termo ecologia. Não obstante, os dois vocábulos têm o mesmo radical que vem do grego oikos que significa "casa". Em seus sentidos etimológicos o termo economia designa "administração da casa" e o termo ecologia se refere a "estudo da casa". Entretanto, "casa" no sentido usado em economia vai se restringir aos aspectos humanos do ambiente, que envolvem a organização social e o modo como usamos os recursos. Já no sentido da ecologia, "casa" é entendido em um sentido mais amplo que envolve os aspectos da vida dos seres vivos em sua relação com os outros seres e com os elementos não-vivos que os sustentam.

Alcançar uma ligação entre estas áreas do conhecimento as quais a gestão dos recursos naturais ou ambientais suscita, requer também um conhecimento aprofundado das razões que explicam a dinâmica da sociedade contemporânea. E sabendo como surgem outras disciplinas que procuram dar respostas úteis para a gestão ambiental a economia aprofunda esta investigação e volta a consolidar sua reflexão. 0 propósito declarado de conectar a reflexão desde diferentes pontos de vista e áreas do conhecimento é fruto de um duplo e óbvio reconhecimento de que a economia não explica de per si todo o problema elencado nesta discussão. Por um lado, é necessário reconhecer que é difícil enfrentar seriamente os problemas ecológicos ou ambientais em que a gestão quotidiana suscita, sem ter um conhecimento físico e territorial preciso deles. Além de admitir que, por mais que se conheça seu aspecto físico e territorial, seria ingênuo pensar em resolvê-los sem levar em conta o quadro institucional e os mecanismos de avaliação que os originam.

Apesar deste aparentemente distanciamento conceitual, as duas concepções vão caminhar juntas para um melhor entendimento do ambiente em que vivemos. Isto levou os especialistas dessas duas áreas do conhecimento a dialogarem, tendo em vista a crise ambiental que foi instalada nas últimas décadas. Tal crise por sua vez é compreendida como uma consequência da busca desenfreada pelo crescimento econômico, que está implícito na visão de que o sistema econômico e o ecológico estão separados. As consequências dessa visão foram sentidas através do 
aumento da poluição das águas, do solo, do ar, do desmatamento de florestas nativas, desequilíbrio nos ecossistemas, extinção de espécies, aumento da temperatura em sistemas ambientais, etc. A partir disso, a noção de um desenvolvimento que envolva um ambiente humano integrado com o natural ganhou força e relevância nas discussões cientificas, no qual decorre o conceito de desenvolvimento sustentável.

Neste sentido, extrapolando sua base puramente ambiental, o desenvolvimento sustentável, que surgiu na década de 1980, diferentemente da ideia dominante no ambientalismo radical nas décadas anteriores, encontra seus fundamentos também nas novas contribuições sobre a natureza do desenvolvimento que influenciou o pensamento econômico do século XX. Esta perspectiva contrapõe-se a visão dominante nas décadas anteriores, no qual acreditava-se que o progresso econômico era somente alcançado através do aumento na produção, baseado principalmente nos conceitos de eficiência econômica. No início da década de 1970, o grande e crescente nível de pobreza nos países em desenvolvimento e a ineficiência do sistema econômico para alcançar benefícios sociais, levaram as entidades internacionais a englobarem outros aspectos do desenvolvimento para a discussão ambiental. A visão do desenvolvimento sustentável transformou-se para dessa forma incorporar objetivos de natureza social, econômica e ecológica.

Partindo desta visão, o estudo em questão tem em seu objeto central a interrelação existente entre os objetivos ecológicos e econômicos do desenvolvimento sustentável. $\mathrm{Na}$ abordagem desta pesquisa, a visão de desenvolvimento sustentável envolve o entendimento de que o bem-estar per capita no sistema econômico aumenta na medida em que o equilíbrio no sistema ecológico é restabelecido. A teoria moderna do desenvolvimento sustentável se baseia na capacidade do sistema econômico gerar bem-estar para sociedade por meio do aumento de bens de capital. Sendo o capital dividido em capital humano, capital natural e capital social. A condição para a sustentabilidade nesta perspectiva acontece quando o somatório desses ativos, ou seja, a soma do capital humano, natural e social, aumenta em termos per capita ao longo do tempo.

O capital natural, entretanto, apresenta uma vulnerabilidade maior no ambiente de mercado por não ter seu valor internalizado no sistema de preços, 
devido ao limitado conhecimento, até poucas décadas atrás, disponível sobre os sistemas ecológicos. Partindo desse pressuposto, se faz necessário a criação de áreas naturais que são separadas do seu uso padrão para serem usadas como fornecedoras de bens e serviços ambientais. As áreas protegidas entram na discussão sobre a proteção ambiental bem antes do conceito de desenvolvimento sustentável tomar forma e tiveram sua ampliação principalmente no século XX. Aqui no Brasil, um dos instrumentos criados pelo poder público para a criação de áreas protegidas, que tem como objetivo frear o avanço do desflorestamento e a degradação de áreas com relevantes riquezas naturais é a Lei 9.985/00, que instituiu o Sistema Nacional de Unidades de Conservação (SNUC). Desde sua criação, no ano 2000, muitas áreas foram criadas em todo o território nacional.

As áreas protegidas têm capacidade de geração de valor em suas múltiplas formas para indivíduos e instituições. Em algumas pesquisas sobre o assunto se testou a hipótese de que as áreas protegidas são subvalorizadas e o resultado foi positivo. Com isso, alguns autores defendem que descobrir, investir e comunicar este valor "escondido" que reside em muitas áreas protegidas, pode promover maior apoio público para a gestão das áreas protegidas e gerar novas fontes de renda para sua proteção. A subestimação dos benefícios das áreas protegidas pode acontecer devido à dificuldade de determinação de valores monetários e os mecanismos convencionais de mercado não são efetivos em fornecer a quantidade socialmente ótima de área protegida. Com isso, são necessárias medidas que comumente requerem a intervenção governamental.

Por outro lado, é importante destacar que vivemos imergidos em um sistema econômico em que as leis do mercado regem a alocação e distribuição dos principais recursos existentes para o consumo da população. Isto implica que qualquer política pública que desconsidere este fato tende a se tornar ineficaz ou obsoleta, não realizando os objetivos para o qual foi criada e sendo esquecida pela maior parte da população. Neste sentido, a criação de áreas protegidas, principalmente quando próxima a regiões urbanas, pode causar efeitos positivos ou negativos nos agentes econômicos, gerando um resultado algumas vezes contrário ao idealizado inicialmente pelo objetivo de criação da área. Estes efeitos positivos ou negativos, benefícios ou custos, que acontecem devido à ação de um agente (na maioria dos 
casos de criação das áreas protegidas no Brasil trata-se de uma ação governamental) sobre outro agente de forma involuntária são chamados de externalidades.

Tendo em vista esta complexidade de fatores na implementação de uma política ambiental, o estudo observou o processo de externalidade gerado pela criação de uma área protegida, que até o ano de 2020 era conhecida como Parque do Poeta ${ }^{1}$, no mercado imobiliário do município de Campina Grande-PB. 0 antigo Parque Estadual do Poeta e Repentista Juvenal de Oliveira (Parque do Poeta), uma área de 267 hectares de caatinga, que se encontra localizado no perímetro urbano do município de Campina Grande - PB (Figura 1) foi recentemente desafetado pelo governo estadual (Lei no 11.797/2020). A área, porém, possui muitas riquezas naturais típicas do bioma Caatinga e está em franca expansão de seu potencial turístico, principalmente para atividades de ecoturismo. A vegetação no parque é típica de uma zona de transição constituída por uma região preponderante de tropófitas que se mistura com xerófilas.

A área está localizada no entorno dos bairros do Mirante, José Pinheiro e Monte Castelo, no município de Campina Grande - PB. O município é a segunda cidade mais populosa do estado da Paraíba e se destaca por ser um importante polo industrial na região Nordeste além de centro universitário. Com isso, o mercado imobiliário é um setor econômico que cresce a cada dia com empreendimentos modernos e se destaca pela alta geração de empregos em toda a cadeia produtiva. Dentro desse contexto, existe em Campina Grande um fenômeno comum que acontece em grandes cidades do Brasil, o aumento da procura por moradia de alto padrão em zonas conhecidas como periurbanas que contém ali de forma implícita um nível maior de bem-estar proporcionado pelo ambiente natural, aumento este que gera uma valorização ${ }^{2}$ imobiliária nestas regiões. Entretanto, por vezes, esses empreendimentos podem contribuir no aumento da degradação ambiental e isso vem acontecendo na área protegida em estudo.

Para fins desta pesquisa, a externalidade é mensurada em unidades monetárias utilizando-se de uma técnica para valoração de bens e serviços

\footnotetext{
1 Felizmente, a Câmara de Veriadores do município de Campina Grande está discutindo a Lei nº325/2020, que cria o Parque Municipal Serra da Borborema, que "deverá preservar, sempre que possível, os limites do antigo Parque Estadual do Poeta e Repentista Juvenal de Oliveira".

2 Aumento de valor ou preço de um objeto, produto, mercadoria, em razão de melhoria em seu conteúdo, por escassez no mercado ou aumento de procura (AULETE, 2006).
} 
ambientais, que está inserida entre os objetivos econômicos e ecológicos do desenvolvimento sustentável. As técnicas de valoração ${ }^{1}$ ambiental são ferramentas metodológicas que vêm ganhado espaço no cenário das ciências ambientais. A atitude de atribuir valor as coisas é considerada uma característica intrisicamente humana e praticada pelas pessoas em várias sociedades na história, porém, o uso de métodos científicos para tal fim é algo recente e envolve um conhecimento multidisciplinar. Assim como ocorre em qualquer pesquisa nas ciências ambientais, as dificuldades metodológicas envolvidas em um trabalho desta natureza se fazem presentes e o trabalho procurou contribuir para o avanço deste campo científico.

Dentro desta perspectiva, os benefícios da conservação do ambiente natural da área protegida são percebidos de forma implícita pelo modelo de preços hedônicos. Com isso, o pressuposto contido é que o mercado pode sinalizar o valor econômico de um ambiente natural protegido. Desta feita, a problemática deste trabalho se insere na questão sobre os benefícios que a sociedade tem com as áreas de conservação e como a teoria econômica pode oferecer respostas em prol da melhoria da implementação de políticas públicas ambientais no Brasil. A partir disto, a pesquisa procura responder a seguinte questão: qual é o benefício da conservação da área protegida, conhecida por Parque Estadual do Poeta e Repentista Juvenal de Oliveira, apreendido pelo mercado imobiliário em Campina Grande - PB? Para se tirar qualquer posicionamento destes questionamentos temse por objetivo geral: analisar os benefícios, em termos marginais, proporcionados pela qualidade ambiental oferecida pelo Parque do Poeta, e por objetivos específicos: estimar o modelo de preços hedônicos do mercado imobiliário em Campina Grande- PB; mensurar o efeito que a qualidade ambiental produzida pelo Parque do Poeta tem no mercado imobiliário e analisar as políticas de proteção das áreas protegidas à luz da teoria econômica ambiental.

Este trabalho será distribuído de maneira pedagógica em cinco capítulos. 0 Capítulo 1, 2, 3 e 4 compõe a revisão bibliográfica do trabalho e o Capítulo 5 abordará os resultados e análises. 0 Capítulo 1 discorrerá sobre estado da arte das áreas protegidas, mostrando sua origem no mundo e seu mais recente conceito, assim como sua formação na legislação ambiental brasileira e sua contribuição na

${ }^{1}$ Ação ou resultado de valorar, de atribuir valor a alguma coisa (AULETE, 2006). 
economia; o Capítulo 2 apresentará uma revisão bibliográfica das principais teorias econômicas que fundamentam a questão da relação entre a economia com o meio ambiente; o Capítulo 3 abordará os princípios metodológicos da valoração econômica de bens e serviços ambientais. No Capítulo 4 será explicitada a teoria dos preços hedônicos e seu uso na valoração de bens ambientais no mundo, assim como a descrição dessa metodologia que foi aplicada no trabalho. No Capítulo 5 será mostrada a análise exploratória dos dados, o processo de modelagem e a discussão dos resultados encontrados. Finalizando o trabalho com as conclusões e as referências bibliográficas. 


\section{CAPITULLO}

\section{ESTADO DA ARTE DAS ÁREAS PROTEGIDAS}

\section{1. ÁREAS PROTEGIDAS NO CONTEXTO INTERNACIONAL}

O Parque Nacional de Yellowstone nos Estados Unidos, criado em 1872, é considerado por muitos especialistas a primeira área protegida de acordo com a conceituação atual. A criação deste parque só foi possível devido a influência de movimentos que ganharam força entre os intelectuais e artistas naquele tempo. Um desses movimentos foi o chamado transcendentalismo romântico, que teve como principais defensores: George Clatin (1796 -1872) e Henry David Thoreau (18171862). Outro movimento que se destacava cada vez mais naquele período foi impulsionado pelo desenvolvimento das Ciências Naturais, que teve como contribuição autores como Carl Von Linné (1707-1778), Charles Darwin (1809 1882) e de Alfred Russel Wallace (1823-1913) exercendo uma enorme influência nos círculos acadêmicos. Dessa forma, a partir destas duas visões de mundo nasceu os movimentos chamados preservacionistas e conservacionistas que influenciam as ações de conservação da natureza no século XX até hoje em vários países (FRANCO et al., 2015).

Com o passar do tempo, os ambientalistas em todo mundo constataram que a conservação da natureza por meio da criação de parques e áreas naturais protegidas era uma forma eficiente de proteção ambiental e esta discussão ganhou uma dimensão internacional. Porém, a instabilidade política existente nos períodos do fim do século XIX até o fim da segunda guerra, impossibilitou grandes avanços nessa questão. Com isso, depois de ter-se formado uma relativa paz no mundo pósguerra e com a ausência de instituições internacionais dedicadas exclusivamente à proteção à natureza, a recém-criada Organização das Nações Unidas para Educação, Ciência e Cultura (UNESCO) foi usada como base para a criação, em 1948, da União Internacional para a Proteção da Natureza (IUPN), que mais tarde, veio a ser 
denominada IUCN ${ }^{1}$ (International Union for Conservation of Nature) (FRANCO et al., 2015).

Diante disso, a IUCN formula um conceito de área protegida, fruto de vários debates científicos que ampliaram o entendimento da importância da área protegida. Para a IUCN (2008) uma área protegida é “um espaço geográfico claramente definido, reconhecido, dedicado e gerido, através de meios legais ou outros meios eficazes, para alcançar a conservação a longo prazo da natureza com serviços ecossistêmicos e valores culturais associados". As categorias de áreas protegidas foram definidas pela IUCN na Assembleia Geral da entidade em Buenos Aires no ano de 1994. Nesse evento, foi elaborado um sistema de categoriais que pretendeu servir como base para os sistemas nacionais e que é válido até hoje. Essa categorização divide as áreas protegidas em: Reserva Natural Estrita, Área Natural Silvestre, Parque Nacional, Monumento Natural, Área de manejo hábitats/espécies, Paisagem terrestre e marinha protegida e Área Protegida Manejada (PUREZA, 2016).

Esta discussão no campo internacional foi se aprofundando e muitos especialistas entendem que um evento decisivo se deu na década de 60 com o lançamento do livro Primavera Silenciosa da bióloga Rachel Carson, no qual alertava a sociedade americana dos perigos para a saúde humana do uso de agrotóxicos nas plantações. Essa pauta, que até então tinha o seu nicho no ambiente acadêmico, entrou de vez nas discussões políticas tanto dos países desenvolvidos como dos chamados emergentes. Nesse contexto, na década de 70 foi realizada a primeira reunião entre países para discutirem sobre o destino do meio ambiente, a Conferência das Nações Unidas sobre o Meio Ambiente Humano ou Conferência de Estocolmo. No Princípio 4 do documento elaborado pela Conferência, a Declaração de Estocolmo, fala que:

O homem tem a responsabilidade especial de preservar e administrar judiciosamente o patrimônio da flora e da fauna silvestres e seu habitat, que se encontram atualmente, em grave perigo, devido a uma combinação de fatores adversos. Consequentemente, ao planificar o desenvolvimento

${ }^{1}$ A União Internacional para a Conservação da Natureza (IUCN) é uma organização internacional e a maior e mais importante rede de conservação ambiental. De acordo com seu site oficial, a IUCN ajuda o mundo a encontrar soluções pragmáticas para nossos mais urgentes desafios ambientais e de desenvolvimento. A IUCN apoia a pesquisa científica; gerencia projetos em todo o mundo; e leva governos, organizações não-governamentais, Agências das Nações Unidas, empresas e comunidades para desenvolver e implementar políticas, leis e melhores práticas de conservação (BHANDARI, 2012). 
econômico deve-se atribuir importância à conservação da natureza, incluídas a flora e a fauna silvestres (DECLARAÇÃO DE ESTOCOLMO, p.3, 1972).

Outro evento internacional que influenciou de forma significativa as ações políticas para a conservação ambiental foi a Conferência das Nações Unidas sobre o Meio Ambiente e Desenvolvimento, realizada no Rio de Janeiro em 1992. Depois de algumas tentativas de encontrar meios para se atingir uma forma de manter o desenvolvimento dos países e preservar o patrimônio natural foi consolidado o conceito de Ecodesenvolvimento, que depois viria a se tornar Desenvolvimento Sustentável, como sendo o caminho ideal para atingir esse fim. Nessa ocasião, foi assinado pelos países participantes um acordo internacional chamado de Convenção sobre Diversidade Biológica (CDB). Nesse acordo consta como objetivos: “a conservação da diversidade biológica, a utilização dos seus recursos naturais e a repartição justa e equitativa dos benefícios derivados de sua utilização e seus recursos genéticos" (MERCADANTE, 2001).

Apesar de não ter se efetivado as metas propostas na $\mathrm{CDB}$, que visavam a redução da degradação da biodiversidade até 2010 , os países participantes da CDB foram efetivos em uma das metas que era a de manter conservado pelo menos $10 \%$ de cada bioma do mundo. Uma das causas dessa conquista se deu devido a propagação das políticas de criação das áreas protegidas no mundo. Com isso, em uma nova reunião que aconteceu na Conferência das Partes do CDB no Japão, os países concordaram em aumentar essa meta até 2020 para obter um nível de conservação de pelo menos $17 \%$ das áreas terrestres e das águas interiores e 10\% das áreas costeiras e marinhas. Para a CDB, as áreas protegidas são consideradas o principal meio de alcançar a conservação da biodiversidade e desde a sua criação em 1992 concentra seus esforços nelas (CORSON et al, 2020).

Desde então a política de criação de áreas protegidas tem sido utilizada como instrumento de conservação dos Recursos Naturais por governos em várias regiões do mundo. Porém, a efetividade dessa prática tem levantado inúmeros debates entre pesquisadores e ambientalistas. Segundo Johannesen (2007), a ampliação das áreas protegidas foi bastante incentivada no continente africano. Sendo que, o cumprimento dos objetivos propostos na criação dessas áreas em muitos casos não acontece. Partindo do indicador de vida selvagem presente na área, Johannsesn 
(2007) mostrou através de modelos econômicos-ecológicos que a expansão da área protegida pode até contribuir para a redução de estoque de animais silvestres e isso acontece principalmente quando a produtividade do trabalho na agricultura dos habitantes locais for menor que a produtividade do trabalho na caça. Para a autora, a melhoria da produtividade agrícola das populações locais promoverá consequentemente a conservação da vida selvagem no interior das áreas protegidas.

Em outra perspectiva, Abman (2018) analisa em que grau a corrupção, a proteção dos direitos de propriedade privada e a estabilidade política estabelecem uma relação com a pressão do desmatamento nas áreas protegidas. Usando dados espaciais explícitos sobre cobertura florestal, desmatamento, limites de áreas protegidas e características da terra, o referido autor estima os efeitos do desmatamento em áreas protegidas nos anos de 2000 a 2012 em 71 países e faz a relação com seus sistemas políticos. Para o autor, existem evidências que mostram uma correlação positiva entre o estabelecimento de um estado democrático, proteção dos direitos de propriedade e baixos níveis de corrupção com uma maior eficácia na governança das áreas protegidas.

Os autores Leberger et al. (2020) estudaram o estado de conservação e as tendências de desflorestamento global nas áreas protegidas, considerando as categorias diversas existentes dentro da classificação adotada pela IUCN. Descobriram que as áreas protegidas tiveram mais perdas do que áreas desprotegidas em algumas sub-regiões, como na Europa Oriental, Mesoamérica e norte da África. Os resultados da pesquisa mostraram que em escala global, as áreas protegidas apresentam resultados positivos com relação à conservação dos recursos naturais. Porém, os autores identificaram que para algumas sub-regiões o nível de desflorestamento para as categorias em que existe uma restrição maior de atuação humana é maior que em categorias onde existe uma flexibilização.

Os esforços globais para reduzir o desmatamento tropical dependem fortemente do estabelecimento de áreas protegidas. Porém, segundo Adam et. al. (2008) a mensuração da eficácia destas áreas para a proteção ambiental não é fácil, pois é difícil medir o provável desmatamento ocorrido no estado de ausência de proteção legal. Neste caso, os métodos convencionais de avaliação do efeito de áreas protegidas podem ser tendenciosos porquê ela pode induzir desmatamentos nas florestas vizinhas que não serão mensurados. Utilizando-se de metodologia que 
buscou escapar deste viés, os pesquisadores avaliaram o impacto sobre o desmatamento no sistema de áreas protegidas da Costa Rica entre 1960 e 1997. Os resultados obtidos mostram que cerca de $10 \%$ das áreas protegidas teriam sido desmatadas se não tivesse tido uma proteção legal. Os autores descobriram também que o desmatamento se espalhou das áreas protegidas para as não protegidas e isto mostra que ainda existe déficits de áreas protegidas no país. Consideram ainda que os métodos empíricos utilizados podem ajudar na gestão dessas áreas principalmente contribuindo com um melhor entendimento das relações existentes entre os sistemas humano e natural (ADAM et. al., 2008).

\section{2. ÁREAS PROTEGIDAS NO CONTEXTO BRASILEIRO}

Em relação ao Brasil, o termo utilizado com conceito similar para o de área protegida é unidade de conservação (UC). Sendo a primeira área protegida criada ainda no regime imperial com a criação da Floresta da Tijuca, que depois em 1961 foi transformada em Parque Nacional da Tijuca. As unidades de conservação nos moldes atuais só foram criadas depois da Constituição de 1934 que outorgava à natureza a função de patrimônio nacional e a partir dela foram criados o Parque Nacional do Itatiaia (1937), Parque Nacional do Iguaçu e o Parque Nacional da Serra dos Órgãos (1939). Entretanto, a motivação existente até a década de 60 para a criação de unidades de conservação era de caráter estético e de acordo com circunstâncias políticas favoráveis. Ainda não havia até então, uma política centralizada de criação de áreas protegidas cujo objetivo fosse garantir a conservação de amostras representativas dos vários ecossistemas existentes no território brasileiro (MERCADANTE, 2001).

Antes da Constituição de 1988, que no Art. 225 impõe ao poder público a definição de espaços especialmente protegidos, existiam algumas categorias de unidades de conservação que desempenhavam objetivos distintos no ordenamento jurídico brasileiro, porém, essas categorias ainda não eram integradas e organizadas dentro de um sistema planificado. Isso consequentemente dificultava as ações de manejo, criação e gestão dessas áreas. Existia também uma pressão de organizações internacionais como a IUCN que buscava uma padronização das áreas protegidas em todo o mundo. Tudo isso levou a uma necessidade de estabelecer os fundamentos legais de novas categorias de unidades de conservação, assim como de uma lei que 
organizasse todas essas categorias em um sistema ordenado que visasse o processo de seleção, criação e gestão dessas áreas com o objetivo central de conservação ambiental (MERCADANTE, 2001).

A Lei 9.985/00 veio para suprir essa necessidade e para efetivar os objetivos da Política Nacional de Meio Ambiente. A referida lei institui o Sistema Nacional de Unidades de Conservação da Natureza (SNUC) e estabelece critérios e normas para a criação, implantação e gestão das unidades de conservação. O SNUC (Sistema Nacional de Unidades de Conservação) visa garantir a viabilidade dos objetivos nacionais de conservação da biodiversidade a longo prazo e para isso organiza em seu sistema um conjunto de áreas protegidas orientando o seu planejamento, manejo e gerenciamento. Com isso, a criação de um sistema único é considerado um marco no avanço da conservação ambiental no Brasil. O SNUC foi responsável por regularizar os critérios necessários para a criação dessas áreas, estabeleceu as categorias de manejo e definiu objetivos para os vários tipos de categorias, o que anteriormente era disperso em variados instrumentos legais (SILVA, 2015).

Segundo a SNUC (Lei 9.985/00), uma unidade de conservação é um "espaço territorial e seus recursos ambientais, incluindo as águas jurisdicionais, com características naturais relevantes, legalmente instituído pelo Poder Público, com objetivos de conservação e limites definidos, sob regime especial de administração, ao qual se aplicam garantias adequadas de proteção". As categorias existentes no SNUC, são divididas em dois grupos: as de Proteção Integral e as de Uso Sustentável. De acordo com a referida lei, o objetivo central das Unidades de Proteção Integral é "preservar a natureza, sendo admitido apenas o uso indireto dos seus recursos naturais, com exceção dos casos previstos nesta Lei”. Para a Unidade de Uso Sustentável, o objetivo é "compatibilizar a conservação da natureza com o uso sustentável de parcela dos seus recursos naturais". Nos grupos de Unidades de Proteção Integral e Uso Sustentável existem doze categorias. Para as de Proteção Integral as categorias são: Estação Ecológica, Reserva Biológica, Parque Nacional, Monumento Natural, Refúgio de Vida Silvestre. No caso do grupo de Uso Sustentável são: Área de Proteção Ambiental, Área de Relevante Interesse Ecológico, Floresta Nacional, Reserva Extrativista, Reserva de Fauna, Reserva de Desenvolvimento Sustentável e Reserva Particular do Patrimônio Natural. 
As Estações Ecológicas (ESEC) foram incorporadas na legislação desde o ano de 1977 com a Lei no 6.513 na qual a categoria foi colocada como área especial de interesse turístico. 0 objetivo dessa categoria, segundo o Art. 9 da SNUC é a "preservação da natureza e a realização de pesquisas científicas". Com o SNUC essa categoria sofreu algumas alterações em suas regras. Atividades de alteração no ecossistema foram permitidas, desde que o objetivo fosse a restauração, assim como o manejo de espécies para fins científicos, cuja ação fosse feita em no máximo 3\% da área da ESEC, diferentemente da regra anterior que era de $10 \%$ da área. Com relação à visitação pública, esta ficou permitida apenas com objetivo educacional (PUREZA, 2016).

Segundo o Art. 10 da SNUC, as Reservas Biológicas têm como objetivo "a preservação integral da biota e demais atributos naturais existentes em seus limites, sem interferência humana direta ou modificações ambientais, excetuando-se as medidas de recuperação de seus ecossistemas alterados e as ações de manejo necessárias para recuperar e preservar o equilíbrio natural, a diversidade biológica e os processos ecológicos naturais". Segundo a referida lei, a visitação pública nessa categoria só é permitida para fins educacionais, assim como acontece nas Reservas Extrativista, e as pesquisas científicas só são permitidas com autorização prévia da administração da unidade, podendo sofrer restrições de acordo com regulamento vigente.

A categoria Parque Nacional é o tipo de categoria mais antigo criado no mundo e seu conceito já passou por várias modificações. Na 10ª Assembleia Geral da IUCN em 1969, aconselhou-se que a categoria fosse implementada somente em “em áreas onde um ou mais ecossistemas não estivessem alterados materialmente pela exploração e ocupação humanas, onde a responsabilidade geral coubesse ao Estado e onde se permitisse a entrada de visitantes" (PUREZA, 2016). Segundo a SNUC, o objetivo básico do Parque Nacional é "a preservação de ecossistemas naturais de grande relevância ecológica e beleza cênica, possibilitando a realização de pesquisas científicas e o desenvolvimento de atividades de educação e interpretação ambiental, de recreação em contato com a natureza e de turismo ecológico".

A categoria Monumento Natural foi regulamentada pela SNUC e seu objetivo básico definido pela lei é "preservar sítios naturais raros, singulares ou de grande 
beleza cênica". Nessa categoria, a área pode ser constituída de propriedades particulares. 0 órgão responsável pode desapropriar as terras de um particular para a criação dessa unidade de conservação. A possibilidade de visitação pública nessa categoria precisa está vinculada no seu plano de manejo e por ser uma unidade de proteção integral precisará, segundo a SNUC, possuir um Conselho Consultivo para a sua gestão. A última categoria de proteção integral presente na SNUC é o Refúgio de Vida Silvestre. Segundo a lei, o objetivo dessa categoria é "proteger ambientes naturais onde se asseguram condições para a existência ou reprodução de espécies ou comunidades da flora local e da fauna residente ou migratória".

Entre as áreas de Uso Sustentável a de Proteção Ambiental (APA) é "uma área em geral extensa, com certo grau de ocupação humana, dotada de atributos abióticos, bióticos, estéticos ou culturais especialmente importantes para a qualidade de vida e o bem-estar das populações humanas" com os objetivos básicos de "proteger a diversidade biológica, disciplinar o processo de ocupação e assegurar a sustentabilidade do uso dos recursos naturais". Alguns especialistas questionam a existência da APA como categoria de UC, considerando-a mais como instrumento de Planejamento Territorial do que como Unidade de Conservação. Para Pureza (2016) é discutível o papel exercido pelas APAs de serem áreas utilizadas para a conservação da biodiversidade. A autora aponta que, em muitos casos, a criação das APAs serve apenas como um instrumento político para os governantes fazerem suas propagandas e consequentemente isso mascara os números de áreas realmente protegidas no território brasileiro.

Neste mesmo contexto aparece a categoria Área de Relevante Interesse Ecológico (ARIE), que segundo alguns especialistas surge sem estudos aprofundados e sua implementação vem se mostrando ineficiente no cumprimento dos objetivos de conservação. Segundo Pureza (2016), a ARIE possui algumas falhas em seu conceito que podem gerar problemas na gestão dessa área. Isso é refletido no baixo número de áreas criadas dessa categoria. O SNUC conceitua a ARIE como "uma área em geral de pequena extensão, com pouca ou nenhuma ocupação humana, com características naturais extraordinárias ou que abriga exemplares raros da biota regional" e aponta como objetivo da categoria "manter os ecossistemas naturais de importância regional ou local e regular o uso admissível 
dessas áreas, de modo a compatibilizá-lo com os objetivos de conservação da natureza".

Segundo a SNUC, a Floresta Nacional (FLONA) "é uma área com cobertura florestal de espécies predominantemente nativas e tem como objetivo básico o uso múltiplo sustentável dos recursos florestais e a pesquisa científica, com ênfase em métodos para exploração sustentável de florestas nativas". Essa definição contida na Lei é a mesma utilizada pela Organização das Nações Unidas para a Alimentação e a Agricultura (FAO), em que as florestas apresentam funções preferenciais com relação à utilização que lhe atribuem. De acordo com a FAO, o objetivo produtivo das Florestas Nacionais é caracterizante (PUREZA, 2016). De acordo com Salomão (1997), as características das FLONAs variam de acordo com as regiões. Nas regiões Sul e Sudeste elas têm maior infraestrutura e maior número de funcionários, assim como fornecem mudas florestais e de madeiras. Na região Nordeste o principal uso das FLONAs é servir como fonte de energia, de alimentos e plantas medicinais. $\mathrm{Na}$ região Norte as áreas possuem problemas de servir como meio de subsistência para populações locais e também não possuem boa infraestrutura.

A Reserva Extrativista (RESEX) segundo o art.19 da SNUC "é uma área utilizada por populações extrativistas tradicionais, cuja subsistência baseia-se no extrativismo e, complementarmente, na agricultura de subsistência e na criação de animais de pequeno porte" e seus objetivos são "proteger os meios de vida e a cultura dessas populações, e assegurar o uso sustentável dos recursos naturais da unidade”. Nessas áreas fica proibida pela lei a utilização de recursos minerais e a caça e somente será permitida a exploração de recursos madeireiros em bases sustentáveis e de acordo com o plano de manejo elaborado para a UC. Para Pureza (2016), existem muitas incertezas com relação à real eficiência da categoria em garantir a conservação da biodiversidade. Segundo o relatório emitido pelo Banco Mundial em 2013 (Managing Forest Resources for Sustainable Development: An Evaluation of World Bank Group Experience) a categoria Reserva Extrativista no Brasil não conseguiu diminuir a perda da biodiversidade e sua contribuição para a qualidade de vida da população foi muito baixa.

A Reserva de Fauna segundo a SNUC é "uma área natural com populações animais de espécies nativas, terrestres ou aquáticas, residentes ou migratórias, adequadas para estudos técnico-científicos sobre o manejo econômico sustentável 
de recursos faunísticos" e a Reserva de Desenvolvimento Sustentável (RDS) é conceituada na referida lei como "área natural que abriga populações tradicionais, cuja existência baseia-se em sistemas sustentáveis de exploração dos recursos naturais, desenvolvidos ao longo de gerações e adaptados às condições ecológicas locais e que desempenham um papel fundamental na proteção da natureza e na manutenção da diversidade biológica". Para Milaré (2011), a distinção existente entre as duas categorias é que o manejo da RESEx tem mais restrições e concentrase na coleta e extração sustentável de recursos naturais e a RDS possui maiores possibilidades para atividades economicamente sustentáveis. Por fim, a categoria de Unidade de Conservação que mais possui unidades criadas é a Reserva Particular do Patrimônio Natural (RPPN). Segundo a SNUC, a RPPN é "uma área privada, gravada com perpetuidade, visando conservar a diversidade biológica”.

Depois da instituição do Sistema Nacional de Unidades de Conservação, houve um aumento significativo das UCs criadas em todo o território nacional. Entretanto, foram observados alguns problemas envolvendo sua expansão e gestão dos territórios criados. Para Santos (2018) por mais que muitas UCs tenham sido criadas desde o SNUC, poucas têm alcançado efetividade em suas finalidades propostas. $\mathrm{O}$ autor estudou as UCs na região do Cerrado e identificou que houve, de fato, muitos espaços protegidos criados nos últimos anos, mas a gestão territorial dessas áreas ainda precisa melhorar. Segundo Santos (2018), a maioria das UCs criadas nessa região se encontra em locais impróprios para a utilização econômica dos recursos, com solos não aproveitáveis para atividades agrícolas. Isto ocorre, segundo ele, devido ao fato de que as áreas com os solos mais aproveitáveis estarem sendo usadas por atividades agrícolas de grande extensão sem levar em conta seus prováveis potenciais ecológicos, ficando as UCs com áreas frequentemente distantes dos polos de atração e com pouca biodiversidade. 0 autor defende que, do ponto de vista ecológico, as UCs devem ser localizadas em pontos estratégicos para que ocorra uma conservação efetiva.

Pereira (2017) observou que há mobilidade e distribuição espacial da população em Unidades de Conservação de uso sustentável na Amazônia. A autora buscou entender como a criação de uma UC impacta a população de determinada região quanto a sua mobilidade e distribuição espacial. Partindo da hipótese de que a criação da UC seria um fator limitante para a permanência dos moradores nessas 
localidades devido a restrições legais do uso dos recursos nela contidos, a autora investiga este fenômeno tomando como objeto de estudo a Reserva Extrativista Auati-Paraná. Os resultados encontrados pela autora mostraram que a maioria dos moradores permanecia em suas localidades mesmo depois da criação da UC, levando ao entendimento de que a criação da unidade de conservação controlou o êxodo rural e contribuiu para o estabelecimento de outras dinâmicas internas no contexto regional. Dessa forma, para Pereira (2017) é preciso sustentar que a criação das UCs "oferece subsídios para autonomia administrativa e financeira dessas áreas, conforme previsto no SNUC" e é importante fomentar a política de criação das Unidades de Conservação como alternativa sustentável ao desenvolvimento econômico.

Tofeti (2018) estudou as transformações ocorridas no uso do território, promovidas pelas UCs. Para o autor, não é possível predizer que as Unidades de Proteção Integral promovem maiores mudanças em seu território que as de Uso Sustentável e observa que para a real implementação da SNUC no território, se faz necessário uma atitude de complementariedade com os diversos atores conflitantes envolvidos na região da UC. Ele considera importante alinhar os diversos fatores envolvidos em uma UC, tanto de natureza ambiental quanto social ou econômica, para que a gestão territorial tenha mais "sucesso". Segundo ele, a gestão das UCs quando ocorre com uma visão mais preservacionista, pode acarretar falta de participação da população local e dos atores envolvidos na região o que afetaria a efetividade da política ambiental.

Em outra perspectiva, Freire et al. (2020) avaliou as UCs de proteção integral no bioma Caatinga usando o método de mapeamento e análise espectro-temporal com o objetivo de averiguar o estado atual de conservação da vegetação nessas áreas. Os pesquisadores observaram que 18,68\% de área das UCs no bioma Caatinga foram degradadas no período entre 2000 e 2017 e isto representa uma perda de biodiversidade considerável para o bioma, tendo em vista que historicamente esse ecossistema já tem sido negligenciado pelas políticas públicas. Uma das possíveis causas para essas perdas segundo o autor, é o baixo nível de indicadores socioeconômicos municipais como o de educação e a renda e isso leva a falta de apoio social que muitas vezes não conhecem a importância da existência das UCs. Outro problema encontrado pelos autores foi a falta de incentivo público na 
manutenção dessas unidades. Segundo Freire et al. (2020) "as UC's estão praticamente abandonadas, sem regularização fundiária, falta demarcação, fiscalização precária e especialistas em fauna e flora, além de apresentarem uma significativa redução de brigadistas e um número insuficiente de servidores do Instituto Chico Mendes de Conservação da Biodiversidade (ICMBio) [...]”.

\section{3. ÁREAS PROTEGIDAS E O DESENVOLVIMENTO ECONÔMICO}

Para Dixon (1991), a existência de baixa quantidade de áreas protegidas ocorre pelo fato de existir uma divergência entre os custos e benefícios privados e públicos que são associados à proteção de áreas naturais. Alguns fatores foram apontados como causadores dessa falha de mercado, dentre eles destacam-se: a subestimação dos benefícios de áreas protegidas devido à dificuldade de determinação de valores monetários, mesmo existindo progressos consideráveis no campo da avaliação; os mecanismos convencionais de mercado não são efetivos em fornecer a quantidade socialmente ótima de área protegida, necessitando de medidas que comumente requerem a intervenção do governo; a análise econômica se mostra limitada na avaliação de alguns benefícios e custos associados à proteção e fatores qualitativos tendem ser muito importantes em alguns casos (DIXON, 1991).

A efetividade da conservação da natureza e da gestão de áreas protegidas são dependentes das preferências e percepções das comunidades locais. Para Walde et. al., (2019) a dependência das comunidades locais dos serviços ecossistêmicos, as percepções do seu potencial econômico e a consciência da existência dos benefícios potenciais das áreas protegidas, definirão a efetiva gestão da área. 0 autor usou uma amostra de 686 entrevistas no Parque Nacional Hoang Lien, no Vietnã, com o objetivo de aferir o uso efetivo do parque, a percepção do parque e sua gestão conforme a avaliação de seus benefícios potenciais. Os resultados mostrados revelam que uma parcela considerável dos entrevistados não tem consciência dos benefícios do parque para as comunidades locais. Walde et. al., (2019) enfatiza que as comunicações dos benefícios de uma área protegida são elementos importantes para os objetivos do desenvolvimento sustentável. As conclusões fornecem evidências de que deixar o desenvolvimento econômico de fora de uma política de conservação não gera satisfação nem aceitação das comunidades locais. Walde et. al., (2019) observa que o turismo gerado pelo Parque Nacional se torna uma 
estratégia viável na superação deste problema. Para o autor, a população percebe o turismo em geral como fonte de renda em potencial e reconhece que o mesmo só é bem-sucedido quando as metas de proteção e conservação do parque são alcançadas. Esta pode ser uma iniciativa promissora para o desenvolvimento sustentável. Quando a população experimentar o turismo sustentável como uma alternativa para o desenvolvimento, as estratégias necessárias para as metas de proteção serão alcançadas (WALDE, et. al., 2019).

As Áreas Protegidas têm a capacidade de geração de valor em suas múltiplas formas para indivíduos e instituições quando geridas com eficácia. Este potencial pode não ter reconhecimento e ser subutilizado quando os objetivos de gestão presentes no Plano de Manejo do parque são limitados. Gamarra (2019) testou a hipótese de que as Áreas Protegidas são subvalorizadas, por meio da avaliação do nível de reconhecimento das diferentes categorias de ativos (entidades, atributos e relacionamentos que podem ser protegidos, administrados e/ou investidos para gerar formas de valor) nos Planos de Manejo em quatro diferentes designações brasileiras (Parques Nacionais, Estações Ecológicas, Áreas de Proteção Ambiental e Florestas Nacionais). Os resultados encontrados mostram que os ativos Humanos e Culturais são os mais subvalorizados e muitas subcategorias de ativos que deveriam razoavelmente estar presentes nos Planos de Gestão não são mencionadas. Neste sentido, a contribuição mais marcante do estudo foi a clara diferença entre o subconjunto pequeno de ativos das Áreas Protegidas que são frequentemente mencionados nos Planos de Manejo e os vários ativos com elevado potencial de geração de valor que não aparecem com a mesma frequência. 0 autor defende que descobrir, investir e comunicar este valor "escondido" que reside em muitas Áreas Protegidas pode promover maior apoio público para a gestão das Áreas Protegidas e gerar novas fontes de renda para sua proteção (GAMARRA, 2019). 


\section{TEORIA ECONÔMICA E O MEIO AMBIENTE}

Os primeiros trabalhos que tratam da relação economia e o meio ambiente foram realizados pela Resources for the future (RFF) nos anos 50. O RFF é uma organização sem fins lucrativos que desenvolve pesquisas sobre questões ambientais, energéticas e de recursos naturais e sua sede se encontra em Washington, EUA. No entanto, foi a partir da década de 1960 que os problemas ambientais foram introduzidos pela ciência econômica de forma extensiva, devido ao livro Primavera Silenciosa da bióloga Rachel Carson, publicado em 1962. O dano causado pelos agrotóxicos em larga escala foi mostrado na obra de Carson e chamou a atenção da opinião pública. Segundo Pearce (2002), a influência desse alerta para a ciência econômica se deu em três níveis. No primeiro, é que os produtores e consumidores de agrotóxicos eram e são grandes empresas. No segundo nível, a utilização de produtos químicos como o diclorodifeniltricloroetano (DDT) tinha elevado a produtividade agrícola e com isso a produção de alimentos tinha atingido uma escala nunca antes vista. E por último, os economistas que já eram familiarizados com a ideia de que existem custos e benefícios de qualquer forma da atividade econômica consolidaram suas análises (PEARCE, 2002).

Esta mudança ocorreu dentro de um contexto cultural em que a visão dominante era a de que o sistema econômico funcionava com os seguintes pressupostos: as fontes de recursos naturais são inesgotáveis, o processo de produção e o consumo de bens não gera resíduos indesejados e as instituições da sociedade garantem a eficiência distributiva dos recursos. Segundo Mueller (1996), nesta concepção, as relações econômicas se estabelecem dentro de um sistema isolado, focalizando as análises dos fluxos de valor de troca e fatores de produção que ocorrem entre empresas e famílias. As falhas de mercado não eram claras e a teoria econômica ainda não as analisava na perspectiva ambiental devido ao conhecimento ainda limitado sobre os ecossistemas e a reduzida demanda do sistema econômico por recursos. Isso começou a mudar a partir da década de 1960, quando ficou evidente que as externalidades ambientais são parte importante no 
processo econômico, e então começam a surgir abordagens que levam em consideração o meio ambiente (MUELLER, 1996).

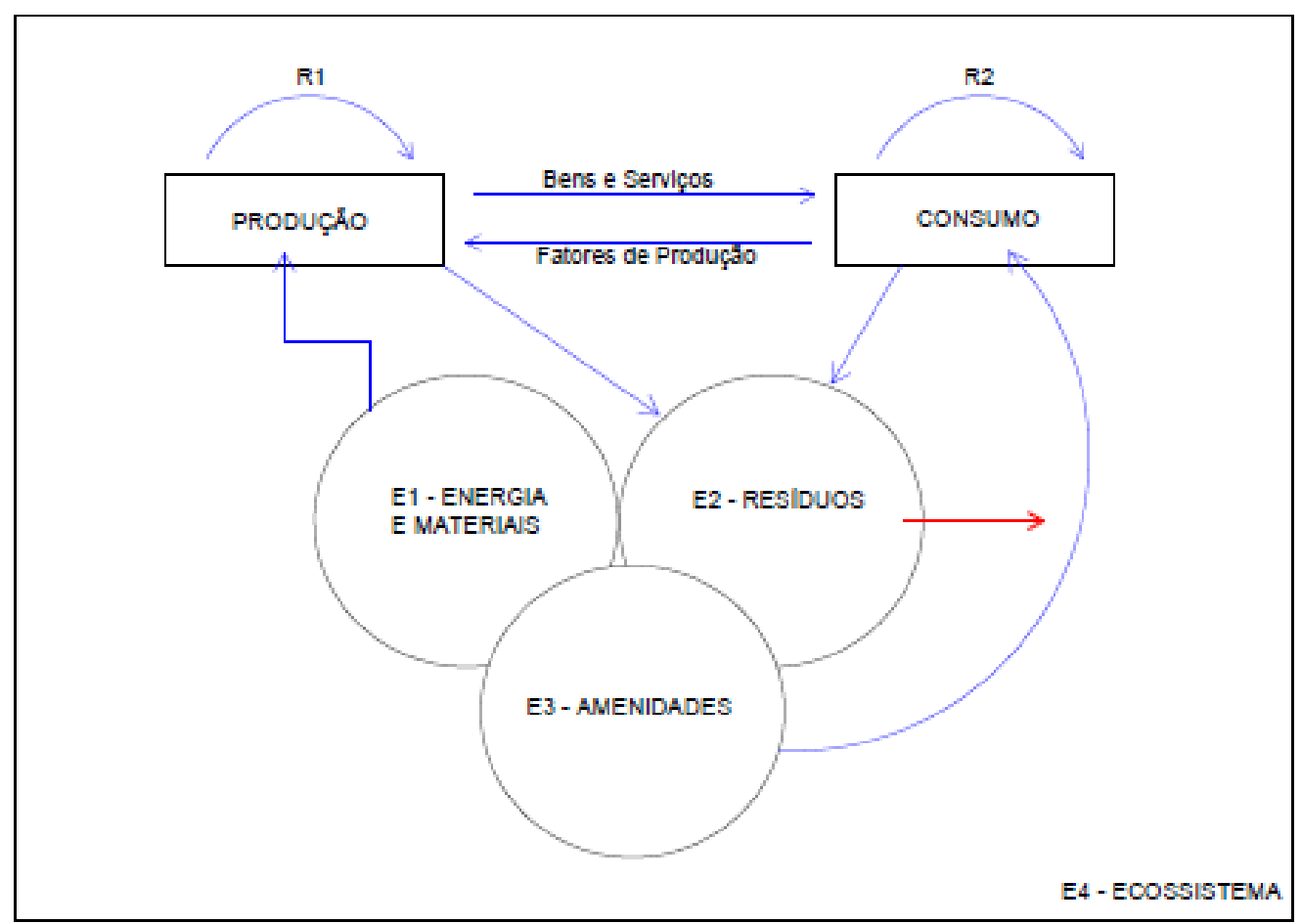

Figura 1- Fluxograma do sistema econômico e sua relação com o meio ambiente. Fonte: Hanley et al., 2018.

As inter-relações da economia com o meio ambiente estão representadas na Figura 1. A economia é identificada em dois setores: produção e consumo. As relações de troca entre os bens, serviços e fatores de produção ocorrem através da produção e o consumo de modo semelhante ao tradicional modelo de fluxo circular. 0 ambiente é representado pelos setores de: energia e materiais (E1), resíduos (E2), amenidades (E3) e o todo do ecossistema (E4). O setor de produção extrai recursos energéticos (tais como petróleo) e recursos materiais (como o minério de ferro) do meio ambiente que são transformados em bens e serviços para serem consumidos pelos indivíduos na sociedade. O resultado da produção e do consumo leva a existência de resíduos que por meio da reciclagem podem voltar ao sistema produtivo, como simbolizado por R1 e R2. A primeira função do meio ambiente dentro deste esquema é, portanto, como um fornecedor de recursos. Outra função seria como um receptor de produtos residuais (HANLEY et al., 2018). 


\subsection{EXTERNALIDADES}

Dentro da perspectiva da nova abordagem neoclássica, os custos assumem a forma de externalidades, que para a questão ambiental materializam-se nos danos ecológicos. Para Pearce (2002), a teoria econômica começou a relacionar a teoria das externalidades, que já era desenvolvida desde 1920 por Pigou, com uma interpretação econômica do emergente movimento ambientalista (PEARCE, 2002). A degradação ambiental nesta concepção, é vista como uma externalidade do sistema econômico, no qual impede uma alocação eficiente dos recursos na sociedade. Com isso, a principal solução que defende essa abordagem é a internalização das externalidades no sistema de preços de mercado. Ou seja, a utilização de mecanismos de controle por parte do poder público, como multas ou taxações, que visem a introdução dos custos sociais e ambientais nos preços de bens e serviços econômicos (QUEIROZ; BORTOLUZI, 2012).

Neste sentido a externalidade é entendida enquanto falha de mercado e existem divergências quanto ao seu conceito. Em geral a externalidade é observada quando as ações de um indivíduo afetam outras pessoas, que não obtém reparação dos danos sofridos daqueles que recebem os benefícios da ação. Hanley et al. apud Arrow (2016) define uma externalidade como "uma situação em que uma economia privada carece de incentivos suficientes para criar um mercado potencial em algum bem, e a inexistência desse mercado resulta em perda de eficiência". A perda de eficiência referida por Kenneth Arrow diz respeito a situações em que uma pessoa ao agir provoca um benefício ou um custo a outra pessoa sem a compensação ou seu consentimento. Para o autor, essa realidade de identificar as externalidades só pode acontecer inserida nos mecanismos de mercado que possuem um sistema descentralizado e com isso facilita a compensação dos benefícios ou custos causados pelas ações dos indivíduos (HANLEY et al., 2016).

Uma externalidade existirá sempre que o nível de bem-estar do indivíduo, seja uma firma ou família, depender não apenas de suas ações, mas também das ações que estão sob o domínio de outro indivíduo. No exemplo mostrado por Tietenberg e Lewis $(2018)^{1}$, o aumento da poluição no rio provocado pela indústria

\footnotetext{
${ }^{1}$ Suponha que duas empresas estejam localizadas à beira de um rio. A primeira produz aço, enquanto
} a segunda, a jusante, opera um hotel resort. Ambos utilizam o rio, embora de diferentes maneiras. A 
siderúrgica impôs um custo externo ao resort, um custo com o qual a empresa siderúrgica precisa internalizar nos preços dos

bens que produz. Esses efeitos externos, ou externalidades, são classificados em: positivos ou negativos. Historicamente, os termos custo externo (deseconomia externa) e benefício externo (economia externa) têm sido usados para se referir, respectivamente, a situações nas quais as partes afetadas são prejudicadas ou beneficiadas por ações de ordem exterior. Entretanto, benefícios externos são menos observáveis pelo sistema de mercado devido ao fato de que muitas vezes os agentes no mercado não os fornecem (TIETENBERG e LEWIS, 2018).

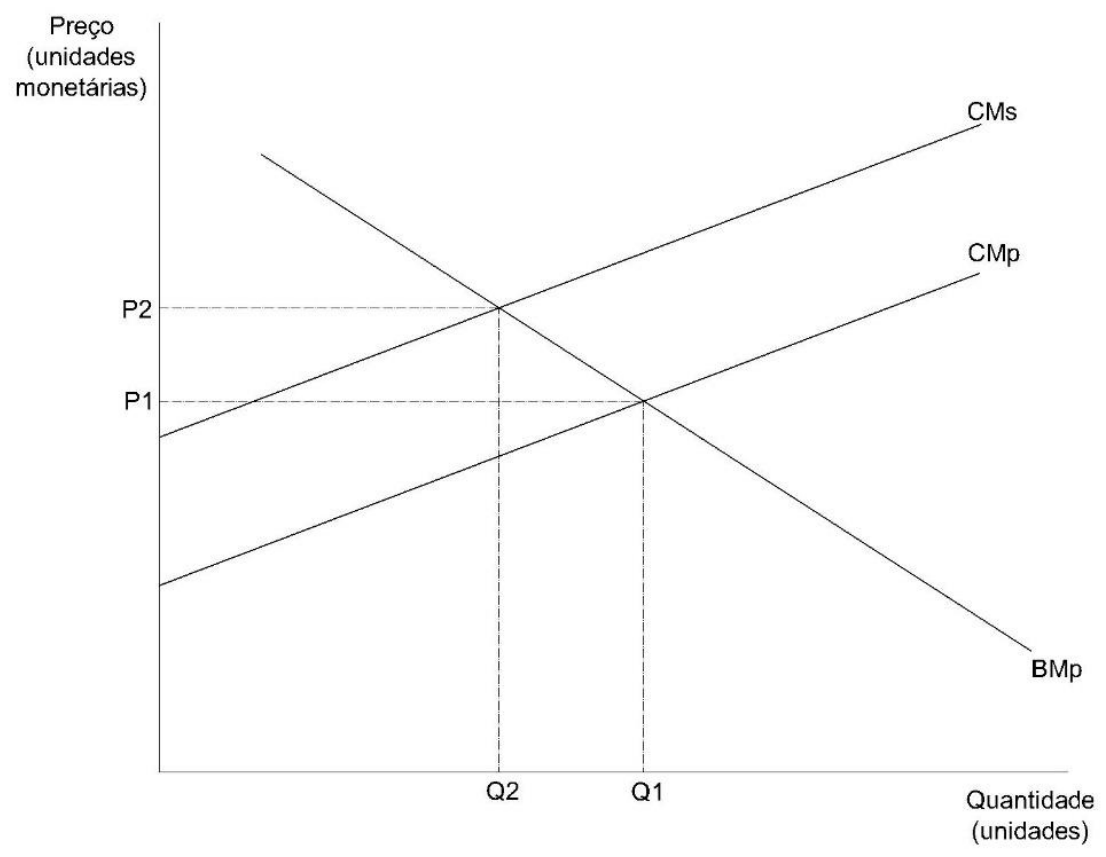

Figura 2- Gráficos de custos marginais e benefícios marginais para externalidade negativa. Fonte: Harris e Roach (2013).

0 efeito da externalidade é ilustrado no gráfico da Figura 2 em que mostra a função benefício marginal (demanda) e a função custo marginal para um bem hipotético. Supõe-se que na produção deste bem inevitavelmente aconteça também a produção de poluição. A demanda por este bem é mostrada pela curva de benefício marginal privado (BMp), e o custo marginal privado de sua produção é representado pela curva CMp. Neste caso, o custo marginal não se restringirá ao custo da produção de forma privada mas incluirá o custo da poluição gerada pela produção,

empresa de aço utiliza o rio como receptáculo para seus resíduos, enquanto o hotel o utiliza para atrair clientes que buscam recreação aquática. Neste caso, a ação poluidora da indústria de aço pode afetar a demanda do resort, causando um prejuízo que não é recompensado pelo autor do dano (TIETENBERG e LEWIS, 2018). 
que será o custo social, ou seja, o custo marginal social será o custo marginal privado somado ao custo de controle da poluição gerada pela produção do bem. Assim, a função de custo marginal social (CMs) incluirá ambos os custos. Para o nível de produção em que o mercado não sofresse nenhum controle externo sobre os níveis de poluição, a quantidade do bem para atingir uma alocação eficiente seria representado por Qm. Essa escolha, em um cenário competitivo, maximizaria seu excedente de produtores privados. Porém, nesta situação em que se tem uma externalidade na produção, a produção atingirá o ponto de alocação eficiente em $\mathrm{Q}^{*}$ (HARRIS E ROACH, 2013).

Para Harris e Roach (2013) as externalidades são definidas como os impactos no bem-estar daqueles que estão fora de uma transação de mercado. 0 exemplo mais estudado de uma externalidade negativa é a poluição. As externalidades negativas são entendidas em função dos danos sociais e ecológicos da poluição, causados pelas decisões de produção das empresas quando operadas sem regulamentação, não são internalizados no processo produtivo. Por outro lado, pode acontecer que em uma transação de mercado a ação de um indivíduo pode beneficiar outro que não pagou pelo benefício. Daí se tem um caso de externalidade positiva. Um exemplo bastante importante para a preservação ambiental de uma externalidade positiva é o caso do benefício proveniente do plantio de árvores por proprietários de terras. Além dos benefícios para o próprio proprietário, as árvores também podem beneficiar aqueles que moram nos arredores e apreciam o cenário e também para sociedade como um todo pela capacidade de absorção do dióxido de carbono e por fornecerem habitat para a biota (HARRIS e ROACH, 2013).

Perman (2003) observa que a eficiência de alocação se altera parcamente na existência de uma externalidade positiva, comparada com o caso de uma externalidade negativa em que o mercado produzirá mais do que é exigido pela eficiência, supondo que as demais condições institucionais no estabelecimento de um mercado de equilíbrio perfeito se mantenham constantes para realizar uma alocação eficiente. Sendo a aplicação conceitual da economia do bem-estar estritamente relacionada aos problemas ambientais, o principal aspecto das externalidades que dizem respeito a poluição do meio ambiente é observado apenas com relação às externalidades negativas. É demonstrado que o mercado, quando não existe políticas coercitivas, pode ser analisado sob três óticas diferentes com relação 
ao problema de poluição: no primeiro caso sobre a ótica de consumidor para consumidor, no segundo de produtor para produtor e no terceiro de produtor para os consumidores. Para o autor, nessas três situações é perceptível que as características essenciais da poluição fazem parte dos problemas de falha de mercado (PERMAN, 2003).

Por outro lado, uma externalidade positiva é um benefício social adicional de um bem ou serviço além dos benefícios privados, ou de mercado. Como uma curva de demanda nos indica os benefícios marginais privados de um bem ou serviço, podemos incorporar uma externalidade positiva em nossa análise como um deslocamento ascendente da curva de demanda. Esta nova curva representa o total dos benefícios sociais de cada unidade. A Figura 3 mostra o caso de um bem hipotético que gera uma externalidade positiva. Cada unidade do bem reduz os danos ambientais, e com isso beneficia a sociedade como um todo. A distância vertical entre a curva de benefícios marginais privados e a curva de benefícios marginais sociais é a externalidade positiva por unidade, medida em unidades monetárias. Neste exemplo, os benefícios sociais são constantes, portanto as duas curvas de benefícios são paralelas (HARRIS e ROACH, 2013).

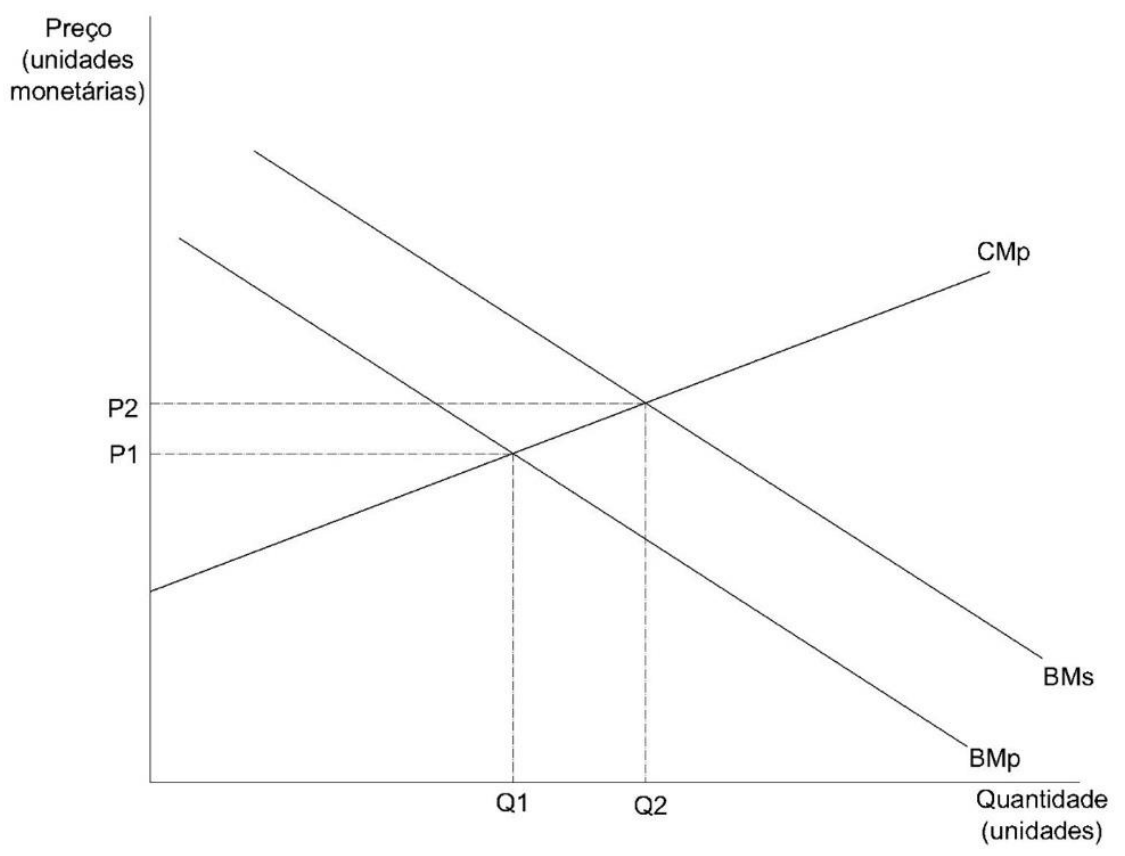

Figura 3- Gráficos de custos marginais e benefícios marginais para externalidade positiva. Fonte: Harris e Roach (2013). 
Segundo Perman (2003) a principal característica dos efeitos externos decorre principalmente da ausência de pagamentos ou compensações pelos danos. Os efeitos externos vão surgir em uma situação em que as ações de indivíduos interferem em outros que não são recompensados ou quando o dano não é punido. Esta falta de recompensa ou punição dentro de um sistema de mercado seria manifestada por meio do mecanismo de sistema de preços onde os danos seriam visualizados em unidades monetárias. A ferramenta usada pelos economistas para atenuar as falhas de mercado que as externalidades negativas promovem é utilizarse de meios para que se tenham a clarividência delas, como a criação de um mecanismo de recompensa ou punição para os efeitos benéficos ou prejudiciais das ações humanas (PERMAN, 2003).

Uma contribuição importante neste sentido foi dada por Ronald Coase em seu artigo "Problem of Social Cost". Coase observa duas situações que poderiam ocorrer dentro da lógica das externalidades. A primeira situação era a da criação de um tributo sobre o poluidor, criador da externalidade, ou outra forma de regulamentação que impunha um ônus ao mesmo. A segunda envolvia o pagamento do poluído ao poluidor para não poluir. Na primeira situação, seria o poluidor quem paga e, na segunda, aquele que sofre o dano. Coase argumentou que, em termos de eficiência as soluções eram equivalentes. Para aqueles que se opõem a mais regulamentação estatal, o argumento de Coase abriu uma possibilidade para o chamado ambientalismo do livre mercado. Embora a segunda situação seja normalmente rejeitada e compreensivelmente injusta, dentro de um contexto real em escala global habitualmente ocorre que o poluidor é um agente de baixa renda e o que sofre é um agente de alta renda. Esta situação ocorre constantemente, por exemplo com os Estados que sofrem poluição transfronteiriça que frequentemente fornecem subsídios e tecnologia para o melhoramento das técnicas poluidoras nos países que poluem (PEARCE, 2002).

\subsection{BENS PÚBLICOS}

Segundo Samuelson (2012) um tipo de externalidade é um bem público, que é entendido como um bem final em que seus benefícios são distribuídos a todos sem que exista a possiblidade de impor alguma restrição ao seu consumo. Em outras palavras, os bens públicos são bens "cujos benefícios são indivisivelmente 
distribuídos a toda a comunidade, quer as pessoas queriam, quer não, consumi-los". Este tipo de bem difere dos bens privados, que são aqueles que "podem ser divididos e proporcionados de forma separada a diferentes pessoas, sem os benefícios ou custos externos para os outros" (SAMUELSON, 2012).

Neste sentido, os bens públicos apresentam duas características principais: a não exclusividade e a não-rivalidade. Embora o bem público no seu sentido estreito, em que as duas características mencionadas sejam completamente manifestadas, seja uma possibilidade apenas no campo teórico, o que se observa nos bens ambientais é que possuem características que se assemelham muito aos bens públicos. Consequentemente, os direitos de propriedade sobre tais bens não podem ser totalmente definidos dentro da lógica de mercado onde as mercadorias são transacionadas. Isto torna os bens ambientais considerados não comercializáveis. Com isso o valor dos benefícios obtidos dos mesmos, no qual os bens ambientais proporcionam às pessoas e à sociedade, que não são quantificados dentro do sistema de preços no mercado, precisam ser mensurados usando outras técnicas. (BÖRGER, 2012).

A distinção de bens e serviços privados e os bens públicos ocorre dentro da definição dos direitos de propriedade, que são completamente definidos para os primeiros e não muito bem definidos para os segundos. Esta completa definição dos mesmos permite que as trocas realizadas no mercado sejam feitas de forma livre. No caso dos bens públicos, como isto não acontece o sistema de preços se torna incapaz de mensurar seu valor. Isto se dá devido as características de nãoexclusividade e não-rivalidade dos bens públicos (MOTTA, 1996). A característica de não exclusividade se apresenta quando os benefícios do consumo de um bem são indivisíveis. Ou seja, quando o indivíduo consome um bem e outra pessoa não é impedida de consumi-lo no mesmo período de tempo. Já com relação a característica de não rivalidade, os benefícios do consumo de um bem são impossíveis de serem impedidos (CALLAN e THOMAS, 2013).

\subsection{ECONOMIA DOS RECURSOS NATURAIS}

A análise ambiental neoclássica desenvolveu também teorias e modelos ao longo das últimas décadas voltados à extração, pelo sistema econômico, de recursos naturais do ecossistema. Essas teorias se propõem a responder algumas questões 
bases da teoria microeconômica, como por exemplo sobre o padrão ótimo de uso de recursos naturais, a taxa ótima de uso de recursos não-renováveis ou se os recursos naturais estabelecem limites físicos ao crescimento econômico. As respostas a essas questões vêm sendo desenvolvidas a partir dos chamados modelos dinâmicos em análises parciais, na linha da contribuição pioneira de Hotelling (1931). A partir do uso desses modelos é possível encontrar um uso socialmente eficiente na escala temporal de recursos naturais específicos (um mineral; uma espécie de peixe no oceano), e no exame dos impactos das falhas de mercado. Em linhas gerais, essas teorias e modelos são os desdobramentos de teoremas básicos da teoria do bemestar social, utilizando-se como instrumental analítico uma estrutura dinâmica (MUELLER, 1996).

O modelo elaborado por Williams Nordhaus, o DICE (Dynamic Integrated Model of Climate and Economy), enxerga as mudanças climáticas na perspectiva da teoria do crescimento econômico. Nesta abordagem, os Estados Nacionais fazem investimentos em capital, educação e tecnologias. O modelo DICE acrescenta o capital natural, do sistema ambiental, como um tipo adicional de estoque de capital, por destinarem investimentos em capital natural por meio de redução de emissões, diminuindo assim o consumo no presente, as economias nacionais contribuem a atenuar mudanças climáticas que seriam danosas para a economia, com isso o consumo no futuro seria aumentado. O modelo de Nordhaus (2014) assume algumas variáveis como dadas ou assumidas. Entre estas estão a população, os estoques de combustíveis fósseis e o ritmo da mudança tecnológica, como também variáveis endógenas no modelo como a produção mundial e estoque de capital, emissões e concentrações de $\mathrm{CO} 2$, mudança global de temperatura e danos climáticos (NORDHAUS,2014).

Esta abordagem da economia dos recursos naturais trata os recursos como fornecedores de matérias-primas para o sistema econômico e foca no estabelecimento do equilíbrio intertemporal atingindo por meio da alocação ótima dos recursos de acordo com a tese de Hotelling (1931) (QUEIROZ; BORTOLUZI, 2012). A diferença entre as duas é que a economia dos recursos naturais concentra os estudos nas taxas de esgotamento dos recursos exauríveis e a determinação de taxas ótimas para extração de recursos renováveis e a economia ambiental por outro lado, centra na poluição (PEARCE, 2002). Para Field et al. (2017) o meio ambiente 
em sua função de fornecedor de insumos está no escopo de estudo da economia dos recursos naturais, já a economia ambiental trata do estudo do fluxo de resíduos, os outputs do sistema econômico, e seus impactos no ambiente.

\subsection{ECONOMIA ECOLÓGICA}

Em outra abordagem o esforço de compreensão da questão ambiental pelos economistas se dar através do pressuposto de que o sistema ecológico limita a atividade econômica. Isto se desenvolveu principalmente a partir do movimento ambientalista dos anos 60 que começou a focar seus esforços na crítica ao estilo de vida das populações das economias modernas, possuindo uma lógica em que afirmava que o estilo de vida de consumismo fomentado pelo sistema econômico estava colocando o futuro do planeta em perigo, eles defendiam que este modo de vida precisava ser alterado. O trabalho de Boulding (1966) intitulado "spaceship Earth" vai nesse caminho. Para Boulding, o planeta Terra é uma nave espacial que possui matéria e energia finitas, podendo apenas serem substituídas por energia solar, que precisam ser reutilizadas e recicladas para proporcionarem um futuro sustentável. A produção e o consumo passam a ser vistos como algo deletério à vida humana, em vez disso, é preciso conservar os estoques de bens, incluindo o de conhecimento que Boulding previu como um dos meios de melhorar a vida humana sem desperdiçar recursos físicos (PEARCE, 2002).

A mudança comportamental envolvendo os agentes transformadores da realidade foi vista como algo urgente e necessário para a sobrevivência. A partir de Boulding e posteriormente com Georgescu-Roegen (1971) surge uma ramificação da economia do meio ambiente denominada economia ecológica. Os defensores dessa linha de pensamento defendem que o sistema econômico não pode mais crescer se quisermos que o planeta recupere seu estado de equilíbrio. Para Daly e Farley (2004), o crescimento econômico tem um custo para o planeta, não crescemos para um vazio e sim para um planeta que dar suporte a nossa vida e que é finito. Para os autores, a economia neoclássica preocupa-se quase exclusivamente com a alocação eficiente dos recursos escassos. Para a economia ecológica a alocação eficiente é uma questão importante, porém se torna secundária quando comparada com outras questões como a escala e a distribuição. 0 ponto ótimo para a economia ecológica acontece quando o crescimento econômico nos afasta do mundo vazio 
para o mundo cheio, com isso o bem-estar proporcionado pelos serviços econômicos aumenta enquanto o bem-estar proporcionado pelos serviços ecológicos diminui (DALY; FARLEY, 2004).

Georgescu-Roegen (1971) no periódico denominado "The entropy law and the economic process" faz uma crítica a ideia de que a ciência poderia eliminar todas as limitações existentes que pesam sobre o homem, ideia tal que também era dominante no meio dos economistas que acreditavam que o desenvolvimento tecnológico resolveria o problema da escassez de recursos naturais. Para o autor, todo o bem que é produzido no processo econômico se utiliza de quantidades extraídas com baixa entropia e no final do processo descarrega matéria e energia de alta entropia. Em um sistema fechado a tendência natural, segundo a Lei da Entropia, é que a quantidade de energia utilizável seja perdida constantemente, aumentando a entropia do sistema que é uma medida de desordem do sistema, ou seja, a ordem de um sistema fechado tende a se transformar em desordem na medida em que a manutenção do sistema requer consumo de energia constante (GEORGESCUROEGEN, 1971).

Segundo a primeira lei da Termodinâmica a energia não pode ser criada nem destruída e só é possível ao homem transformá-la, ou seja, a produção econômica é dependente da energia acumulada na natureza que é fornecida de forma gratuita. A segunda lei da Termodinâmica vai falar que mesmo que sua quantidade de energia se mantenha constante dentro de um sistema fechado, a sua qualidade pode ser alterada. 0 processo de produção transforma os recursos em algo que pode ser utilizado pelos seres humanos, porém para acontecer essa transformação é necessário trabalho e para obter o trabalho só através do uso de energia de baixa entropia ou energia livre. Para a economia ecológica a natureza do sistema econômico pode ser entendida através das leis da Termodinâmica. A primeira lei alerta para a dependência entre a economia e os recursos naturais e a segunda lei mostra que apenas a energia livre ou de baixa entropia é a única forma enérgica de realizar trabalho que é utilizável na produção e, portanto, impõe uma limitação de crescimento ao sistema econômico (DALY; FARLEY, 2004). 


\section{VALOR ECONÔMICO DE BENS ESERVICQOS AMBIENTAIS}

O uso de métodos de avaliação econômica se tornou um instrumento pertinente para a avaliação de projetos públicos de conservação dos bens ambientais. Esta tendência reflete o entendimento de que a existência de bens ou amenidades ambientais por um lado tem um impacto benéfico para a sociedade, bem como para o sistema econômico, por outro lado, sua proteção vem ao custo de uma redução do poder de compra da população através do aumento de tributos. A melhoria da qualidade do ar nas cidades através de uma redução das emissões de partículas poluentes ou pela conservação de áreas naturais, desacelerando o desenvolvimento industrial, por exemplo, requer considerações sobre os benefícios esperados de tais medidas em relação aos custos a serem incorridos pela sociedade como um todo. Especialmente em tempos de crescentes restrições fiscais, esta avaliação é importante na criação de indicadores para as mudanças no bem-estar da sociedade resultante de tais projetos ambientais, contribuindo com isso no processo de tomada de decisão das políticas públicas. Neste sentido, a medição dos benefícios destes bens para a sociedade se faz importante e também apresenta diversas dificuldades (FRÖR, 2007).

Neste contexto, uma questão que tem sido debatida tanto por economistas de vertente neoclássica como por economistas ecológicos é sobre o valor do meio ambiente. 0 conceito de valor é discutido há séculos nas ciências econômicas. Autores clássicos como Adam Smith consideravam o valor como sendo constituído de dois sentidos, o primeiro dizia respeito à utilidade contida nos objetos e o outro com relação ao poder de compra dos mesmos em relação à outra mercadoria. Para David Ricardo, o valor é originado da escassez e da quantidade de trabalho necessária para obter a mercadoria. Outro autor conhecido, Alfred Marshall, tem uma visão diferente dos autores clássicos. Para ele, o valor tem relação com a satisfação do consumo de uma mercadoria. Assim, o valor seria medido a partir do conceito de utilidade, que diz respeito ao quanto uma pessoa sente prazer com aquela mercadoria (MOTA; BURSZTYN, 2013). 
A economia ambiental utiliza este último conceito em suas análises, tendo em vista que suas bases estão no individualismo metodológico, utilitarismo e equilíbrio. Para essa concepção o bem-estar é visto como uma categoria nãoeconômica que reflete o conjunto de todas as categorias não-econômicas dos valores sociais (AMAZONAS, 2009). Para Field et al. (2017) "a criação de valor gerada pelas ações econômicas baseia-se na noção fundamental de que os indivíduos têm preferências por bens e serviços". Os autores consideram que o valor de uma mercadoria para uma pessoa está relacionado com o quanto ela está disposta a sacrificar para consegui-la. Ou seja, sua disposição a pagar por um determinado bem.

Dentro desta perspectiva, a determinação do valor econômico de um recurso natural, para Motta (1997), consiste em estimar o seu valor monetário em relação aos outros bens e serviços do sistema econômico. A necessidade dessa atividade se dar principalmente devido ao fato de que os gestores públicos trabalham com orçamentos limitados e precisam alocar os recursos de forma a maximizar o bemestar das famílias. Com isso, a análise de custo-benefício será quase sempre a forma adotada para melhor tomada de decisão em tais situações. Daí entra a necessidade da valoração ambiental, pois os benefícios de qualquer política ambiental que venha a ser adotada podem ser medidas através do nível de bem-estar das pessoas que é sinalizado pelo consumo de bens e serviços e isto inclui o consumo das chamadas amenidades de origem ambiental (MOTTA, 1997).

Dessa forma, o gestor decidirá por aquela opção na qual se apresenta como a de melhor custo-benefício possível. Este raciocínio é praticado não só em nível governamental, mas também nas empresas, organizações não-governamentais e também constantemente nas famílias. $O$ agente público precisa tomar a decisão de alocar um orçamento financeiro limitado diante de várias opções de investimentos para atender o máximo benefício possível da população. Da mesma forma em que os indivíduos precisam decidir entre escolhas conflitantes quando consomem bens e serviços. Se o orçamento de todas as opções de projetos de investimento público for menor que a receita orçamentária do órgão público, então todas poderão ser implementadas. Porém, isto dificilmente acontece na gestão pública, onde frequentemente os gastos são maiores do que a receita. Desta forma, o gestor sempre precisará fazer a opção entre um conjunto de investimento em detrimento 
de outro. Ou seja, será necessário sempre ordenar as opções que devem ser preferíveis. (MOTTA, 1997).

A estimação dos custos e benefícios não é uma atividade simples, pois, necessita da capacidade de identificá-los inicialmente e depois da definição dos critérios de decisão para levar os investimentos públicos visando o aumento do bem-estar da população. Sendo assim, a tomada de decisão do poder público sobre a alocação de recursos com um orçamento limitado e muitas vezes insuficiente podem ser melhor realizadas através de uma análise social de custo-benefício. A análise social de custo-benefício objetiva a mensuração do valor social de variadas implicações de um determinado projeto, investimento ou política pública. Os efeitos negativos dos projetos são interpretados como custos sociais e os positivos como benefícios sociais. Dentro deste raciocínio, como se pretende comparar os custos e benefícios, decorre a necessidade de externá-los em uma unidade comum, ou seja, em um mesmo numerário ou medida de conta. Para isso, frequentemente se expressa os custos e benefícios em unidades monetárias (MOTTA, 1997).

Para a teoria econômica neoclássica, o meio ambiente fornece utilidade para os indivíduos, tanto de forma direta, através do espaço físico para sua existência, quanto de forma indireta, possibilitando a produção de bens de consumo. Estes benefícios indiretos e diretos dos recursos naturais são costumeiramente denominados bens ambientais. A diferença essencial entre tais bens e os bens comuns de mercado, tais como cadeiras, alimentos, ou trabalho é sua natureza de bem público dos bens ambientais. Quando os bens ambientais são concebidos, isto é, quando existem na forma de um ecossistema equilibrado, ar limpo ou uma bela paisagem, normalmente ninguém pode ser impedido de usufruir dos benefícios proporcionados por estes bens (BÖRGER,2012).

Nesse contexto, o governo em uma sociedade democrática precisa alocar recursos públicos escassos nas atividades que mais aumentem o bem-estar total da população, de forma que apenas os projetos que os benefícios públicos totais superem os custos sejam realizadas. Com isso, na medida em que os efeitos benéficos para o meio ambiente forem alcançados por esses projetos, é necessário observar se os custos dos mesmos para o bem-estar da sociedade não irão se sobrepor. No mesmo sentido, as consequências ambientais negativas que forem previstas em projetos públicos visando melhorias na infraestrutura precisam ser 
avaliadas com as perdas ao equilíbrio ecológico que eles decorreriam para dessa forma, ocorrer decisões mais assertivas. Essas considerações de custo-benefício precisam utilizar-se de unidades de medidas com o objetivo de comparação entre os benefícios diretos e indiretos com os custos previstos para dado projeto de intervenção pública (FRÖR, 2007).

A valoração econômica de bens ambientais e a análise custo-benefício (ACB) podem servir como subsídios valiosos para as tomadas de decisões. A ACB é construída com base na visão de eficiência Kaldor-Hicks, a qual mostra que em um projeto favorável existem tanto beneficiados quanto prejudicados, tendo que o ponto de eficiência do projeto acontece quando os níveis de benefício ultrapassam os de prejuízo. Para determinar a eficiência de Kaldor-Hicks em uma ACB, os benefícios totais e os custos são tipicamente medidos em dinheiro. As duas medidas usadas para a mensuração do bem-estar são: a variação compensatória (CV) e variação equivalente (EV). Quando o agregado do CV ou EV é positivo, isto indica que o projeto deve ser realizado, uma vez que os ganhos monetários são mais altos do que os custos monetários. É este critério que forma a base para a análise de custobenefício e da moderna economia do bem-estar (NURMI, 2018).

Segundo Amazonas (2009), esta visão da economia ambiental não é compatível com o Desenvolvimento Sustentável, pois, segundo o autor, a realidade sistêmica complexa, incerta e de dinâmica evolutiva do Desenvolvimento Sustentável "transcende a esfera de percepção, conhecimento, julgamento compensatório, formação de opções e motivação dos indivíduos, sendo, portanto, não traduzíveis por meio das preferências destes". Para ele, o uso ótimo dos recursos, objetivo da economia ambiental, não corresponde necessariamente ao uso sustentável dos mesmos. O autor defende que a eficiência é incompatível com a equidade, que é um dos fundamentos do Desenvolvimento Sustentável. Fazendo uma contestação ao individualismo metodológico e ao utilitarismo da teoria neoclássica, elaborou-se um campo teórico composto de uma percepção que centrava a análise no espaço institucional, em vez do indivíduo. Dentro desta análise não se utiliza as preferências individuais como utilidades ou como o fator preponderante dos valores econômicos e sim como o resultado da institucionalização de escolhas e dinâmicas sociais. Tal abordagem constitue um campo que se denomina "institucional" (AMAZONAS, 2009). Segundo Amazonas 
(2009) esse campo compreende concepções com diferentes formulações, sendo o principal ponto em comum entre elas a escolha metodológica que opõe ao individualismo da teoria neoclássica e coloca as instituições como o centro, o que segundo o autor mostra ser uma abordagem mais sistêmica e orgânica, sem que isso seja subordinado às preferências individuais.

Em outra perspectiva, a partir dos anos 60 e 70 foi-se desenvolvendo o entendimento sobre os benefícios da biodiversidade sobre a economia, alguns trabalhos chamaram-no de "funções do ecossistema", "bens e serviços ambientais", "amenidades ambientais" ou simplesmente, "serviços da natureza". Estes primeiros trabalhos são importantes para os atuais esforços de atribuir valor para natureza. É neste contexto geral, que a monetização dos serviços do ecossistema foi defendida principalmente a partir de 1997 como uma estratégia para conseguir que o sistema de mercado internalize as questões ambientais (BAVEYE,2013). Os conhecimentos dos benefícios da proteção ambiental ficaram maiores a partir do trabalho pioneiro de Robert Costanza et al. (1997). No artigo The value of the world's ecosystem services and natural capital, Robert Costanza et al. (1997) observam que os bens (alimentos por exemplo) e serviços (como a assimilação de resíduos) ambientais são benefícios que a sociedade obtém por meio das funções ecossistêmicas. Desde então, o estudo sobre os serviços ambientais ou serviços ecossistêmicos se popularizou e vem ganhando enorme atenção nos projetos de preservação ambiental (PARRON; GARCIA, 2015). Os principais serviços ambientais são apresentados na Tabela 1. 
Tabela 1 - Classificação dos serviços ambientais em serviços de provisão, regulação, culturais e de suporte.

\begin{tabular}{|l|r|r|}
\hline \multicolumn{1}{|c|}{ Categorias } & Exemplos de serviços \\
\hline Serviços de suporte & tenção do ciclo de vida (ciclagem de nutrientes e da água/fotossíntese) \\
Formação do solo
\end{tabular}

Fonte: Milenium Ecosystem Assessement (2005).

Segundo Andrade (2013), os serviços ecossistêmicos ou ambientais são compreendidos como o campo de interação entre os ecossistemas e o bem-estar humano, sem os quais não tem possibilidade de existir vida no planeta. Com isso, pelo grau de importância que os ecossistemas têm para a vida na terra, se faz necessário o conhecimento dos seus valores verdadeiros para dessa forma aplicar políticas públicas mais ecologicamente eficientes de conservação das florestas (ANDRADE, 2013). Sendo assim, os valores atribuídos aos serviços ambientais são classificados como valor de uso e valor de não-uso (VNU) ou valor de existência. Para Motta (1997), o valor de uso pode ainda ser subdividido em valor de uso direto (VUD), valor de uso indireto (VUI) e valor de opção (VO) (valor de uso potencial). Com isso, o valor econômico de um recurso ambiental (VERA) pode ser escrito como: 


$$
V E R A=(V U D+V U I+V O)+V N U
$$

Equação 1

A mensuração destes termos da equação é feita através de sofisticados métodos desenvolvidos no campo de estudo da economia ambiental. Estes métodos estão divididos em métodos da função de produção e métodos da função de demanda. Os métodos da função de produção (produção sacrificada ou custos evitados) consideram o recurso natural como um insumo da produção e a partir da variação destes insumos a mensuração dos recursos é feita. Segundo Motta (2006) "se o impacto altera a quantidade produzida do bem privado, o valor econômico desse impacto pode ser mensurado pela variação de receita líquida desta alteração de produção". Já com relação aos métodos da função de demanda (preços hedônicos, custo de viagem e valoração contingente), a mensuração do valor ambiental é feita através das preferências individuais. A variação do excedente do consumidor é medida em função de uma variação da disponibilidade dos recursos (Motta, 2006). Estes métodos consideram os benefícios como a quantia que as pessoas estariam dispostas a pagar por um determinado serviço ambiental (FIELD, B.C.; FIELD, M.K, 2013). 


\section{CAPITULO IV}

\section{METODOLOGIA}

\subsection{MODELO DE PRECOS HEDÔNICOS}

A metodologia utilizada nesta pesquisa se baseia na modelagem desenvolvida por Rosen (1974), conhecida como regressão hedônica, a partir da qual estima-se o valor implíctio de determinados atributos de um bem, como as amenidades ambientais, por meio de características observáveis no mercado. A função em questão representa o equilíbrio de mercado para um determinado bem a partir do conjunto de suas características, essa abordagem não é capaz de identificar individualmente as preferências do consumidor nem a tecnologia de produção do produtor. Assim, no caso para o estudo, usou-se o bem habitação, em que podemos considerar que a função hedônica assume a forma de $P=F\left(R_{i}, A_{i}, N_{i}\right)$, em que $\mathrm{P}$, o valor de mercado da moradia, é função de $\mathrm{R}_{\mathrm{i}}$, que designa o conjunto de características estruturais do imóvel, de $A_{i}$, que representa as amenidades ambientais e de $\mathrm{N}_{\mathrm{i}}$, que caracteriza a vizinhança na qual o imóvel está situado (SEABRA, 2016).

Rosen (1974) formulou um modelo de diferenciação de produto baseado na hipótese hedônica, no qual os bens são valorizados por seus atributos ou características de utilidade. Uma teoria de preços hedônicos é formulada como um problema na economia do equilíbrio espacial em que todo o conjunto de preços implícitos orienta tanto a localização do consumidor como as decisões do produtor no espaço de características. Os preços hedônicos são definidos como os preços implícitos dos atributos de um bem e são revelados aos agentes econômicos a partir dos preços observados de produtos diferenciados e suas quantidades de características específicas. Essas características constituem a natureza empírica de explicação do modelo. Econometricamente, os preços implícitos são estimados pela primeira análise de regressão por etapas (preço do produto regressivo sobre as características) na construção de índices de preços hedônicos. Portanto, o objetivo principal do modelo, é exibir um mecanismo gerador para as observações em ambiente competitivo e usar essa estrutura para esclarecer o significado e 
interpretação dos preços implícitos estimados. 0 modelo sugere um método que muitas vezes pode identificar parâmetros estruturais subjacentes de interesse. Também, como um ponto metodológico geral, é demonstrado que conceitualizar o problema da diferenciação de produtos em termos de algumas características subjacentes leva a uma análise de equilíbrio espacial (ROSEN, 1974).

Segundo Lancaster (1966) a principal contribuição científica do modelo de preços hedônicos é a consideração de que os bens não são objetos diretos de utilidade e sim, propondo uma ideia mais ampla, de que na verdade são as propriedades ou características dos bens que fornecem a utilidade para os consumidores. $\mathrm{O}$ autor parte do pressuposto de que o consumo é uma atividade na qual os bens, isoladamente ou em combinação, são insumos e a saída é um conjunto de características. Presume-se que a hierarquia de utilidades ou de preferências dos indivíduos partem da soma das características de um bem e apenas de forma indiretamente os bens são ordenados pelo grau de preferência de forma individual através da totalidade de sua natureza (LANCASTER,1966).

O modelo hedônico de preços de imóveis está inserido em uma perspectiva que considera os mercados privados como um meio que sinalisa a disposição a pagar (DAP) dos indivíduos pela qualidade ambiental. Existem milhares de aplicações do método desde sua criação nos anos 70, e o seu uso continua em crescente ascensão nos últimos anos devido ao desenvolvimento das técnicas computacionais. Basicamente o modelo prevê que os compradores escolhem os imóveis com base em características estruturais (como por exemplo, espaço interno, quartos, banheiros, etc) e características de localização (por exemplo, a qualidade do ar, distância próxima a parques, instituições de ensino ou locais com menores riscos de inundação). Supondo um mercado competitivo, a variação de localização das amenidades ambientais é então evidenciada nos preços das habitações. 0 modelo foi aperfeiçoado através dos anos e se tornou uma das principais técnicas para valorização das mudanças na qualidade ambiental em pesquisas acadêmicas, nos litígios e nas políticas públicas (BISHOP, 2020).

Para Bishop (2020), o ponto de partida para a atividade da modelagem de preços hedônicos é uma pesquisa que capta uma variação exógena em uma característica específica do ambiente que pode ser potencializada por compradores (por exemplo, qualidade do ar). 0 autor argumenta que sob condições ideais, a 
derivada da função de preço hedônico pode ser interpretada como uma evidência do valor indireto para o ambiente, que poderá ser usado para calcular a chamada disposição marginal a pagar pela (DAPm) amenidade. Em primeiro momento, o processo de estimativa de DAPm é aparentemente simples. Entretanto, na prática, várias decisões precisam ser tomadas para executar a modelagem, incluindo as medidas de preços de venda e comodidades e a escolha da especificação econométrica (BISHOP, 2020).

As possibilidades de avaliação não mercantil, para bens e serviços que não possuem mercados, utilizando métodos hedônicos são muitas e utilizam-se o mercado imobiliário na maioria dos casos. Esta popularidade do método hedônico se dar talvez por causa dos pré-requisitos que são relativamente mínimos e também por possuir uma implementação empírica simplificada. Além disso, as percepções que se podem extrair em uma análise deste tipo são bastante interessantes: como, por exemplo, na mudança da qualidade ambiental sentida pela população de uma localidade. A escolha realizada pelos consumidores de habitação por uma determinada localidade é o ponto chave observado pela teoria. Estas escolhas de localização são muitas vezes relacionadas diretamente a uma amenidade ambiental de interesse. Como exemplo, pode-se observar intuitivamente que locais de moradia com vistas cênicas apreciadas pela sociedade tem mais valor agredago no valor de propriedades $^{1}$ (TAYLOR, 2003).

Os modelos econômicos em sua maioria buscam observar as interações existentes entre os agentes inseridos no mercado. Assume-se que os consumidores e produtores tomam suas decisões econômicas com objetivos otimizadores, fundamentando-se em informações sobre os preços e em seus interesses individuais e capacidades técnológicas de consumo e produção. Porém, no estudo do impacto

\footnotetext{
${ }^{1}$ A autora imagina o seguinte cenário hipotético: existem dois lagos idênticos com 100 casas idênticas cada um em seu entorno. Todas as casas são próximas ao lago, e todas as características estruturais, da terra e dos bairros são idênticos em todas as propriedades. Em uma situação de equilíbrio geral o preço de todas as propriedades é 200.000 dólares por casa, neste caso todas as 200 casas em ambos os lagos são igualmente preferidas pelos consumidores. Agora, imaginemos que a claridade da água em um lago, o Lago A, é melhorada. Presume-se que a melhoria da clareza da água é preferida por todas as famílias. $\mathrm{O}$ diferencial de preço que resultará da mudança da claridade na água do Lago A é o preço implícito que os consumidores estariam dispostos a pagar por esse aumento adicional de claridade da água. Esta vontade de pagar pela clareza da água nos é revelada indiretamente através dos preços de mercado dos imóveis. Neste caso, se nessa nova situação de equilíbrio, os imóveis no Lago A são vendidos por \$210.000, enquanto os imóveis no Lago B por \$200.000, o "preço implícito" associado ao aumento da clareza da água seria de \$10.000 (TAYLOR, 2003).
} 
das chamadas amenidades ambientais sobre a moradia é necessário transpor essa hipótese inicial, pois, para o mercado de habitação os consumidores não realizam suas escolhas de forma direta sobre a quantidade de qualidade do ar ou de segurança que desejam consumir. Pode acontecer que um novo edifício erguido em uma quadra tira a privacidade dos antigos moradores, que por sua vez não tiveram nenhum benefício ou ressarcimento por isso. Com isso, percebe-se a influência das externalidades ambientais nas decisões dos agentes no mercado habitacional (HERMANN, 2005).

As externalidades ambientais geradas dessas situações tem seu valor desconhecido, pois, como não possuem mercados para esse tipo de bem, fica impossibilitada a observação do seu preço. Com isso, é possível assumir indiretamente que existe implicitamente uma demanda e oferta por essas amenidades. Assim, tenta-se estimar os consequentes preços de mercados para tais bens. 0 modelo de preços hedônicos utiliza-se desse pressuposto para analisar esse fenômeno. Nele, o valor marginal dos atributos é estimado para um bem heterogêneo, e dessa forma encontra-se a quantidade parcelada do valor de cada característica (HERMANN, 2005).

Neste sentido, os bens heterogêneos são bens que contém variações em suas características, mesmo no caso em que são comercializados dentro de mercados semelhantes, causando com isso variações em seus preços de mercado. 0 método de preços hedônicos para análise não-mercadológica se baseia em transações de mercado para este tipo de mercadorias. Como exemplo, podemos observar o diferencial de preço entre modelos idênticos de carros que variam apenas por uma característica (um tem mais potência do que o outro), implicando, de forma indireta, o que as pessoas estão dispostas a pagar pela mudança nesta característica. 0 método hedônico é considerado de avaliação "indireta", pois não podemos observar o valor que os consumidores atribuem para a característica diretamente e sim, inferimos a partir de transações observáveis no mercado (TAYLOR, 2003).

Exemplificando esta idéia central do modelo, Morancho (2003) estima uma função de preço hedônico de imóveis em que a oferta de áreas verdes na cidade de Castellón (Espanha) está relacionada com os preços de venda dos mesmos. 0 modelo usa três variáveis ambientais: a existência de vistas para um parque público, o tamanho da área verde mais próxima e a distância do imóvel para estes espaços. 
Os resultados mostraram que a variável área privativa do imóvel é a que mais influencia o preço da habitação. Com relação às variáveis ambientais, somente a distância para um espaço verde foi significativo no modelo estimado. De acordo com a autora, ao distanciar-se $100 \mathrm{~m}$ de uma área verde, o preço da habitação cai em 1800 euros. Morancho (2003) conclui que a proximidade dos imóveis com espaços verdes no centros urbano de Castellón é mais importante na variação do preço do que o tamanho dessas áreas. Com isso, as políticas públicas precisam levar em consideração a importância de pequenas áreas de parques no planejamento urbano (MORANCHO, 2003).

Aguiar et. al. (2014) usou modelos hedônicos de preços hierárquicos e um modelo hierárquico-espacial no seu estudo para analisar os fatores determinantes dos preços do mercado imobiliário em Belo Horizonte, MG, Brasil. 0 estudo mostrou que amenidades ambientais também influenciam nos preços dos apartamentos, além de características estruturais como a área, idade e padrão construtivo. Os modelos indicaram que variáveis como serviços públicos urbanos e violência urbana explicam até $75 \%$ da variabilidade dos preços de habitação. Para a autora, os governos locais deveriam usar os resultados encontrados no trabalho para coordenarem de forma mais eficiente os mercados imobiliários, tendo em vista que os governos podem se beneficiar de um conhecimento mais aprofundado sobre o funcionanmento do mercado. Como, por exemplo, a autora cita a criação de um imposto sobre os bens imobiliários que levasse em conta as características ambientais da localicade, de forma que possa melhorar os preços de propriedade, implicando assim em uma tributação mais progressista e justa (AGUIAR, 2014).

Percebe-se assim que o principal pressuposto subjacente é que o ambiente influencia os preços dos imóveis. Desta forma, os imóveis localizados em ambientes com uma paisagem atraente possuirão um maior valor agregado comparado com imóveis similares em outro ambiente. Luttik (2000) questiona se este fenômeno que é intuitivamente percebido sempre acontece e se fatores ambientais influenciam nessa escolha de localização. Neste sentido, a autora estudou o efeito de distintos fatores ambientais sobre o preço de imóveis na Holanda usando como o método de pesquisa o modelo de preços hedônicos. Os resultados mais significativos encontrados pela autora foram que: os maiores aumentos nos preços dos imóveis devido a fatores ambientais foram para uma residência com a vista voltada para 
algum corpo hídrico ou para algum espaço verde. 0 estudo mostrou que uma paisagem atraente pode influenciar aproximadamente entre 5 a $12 \%$ dos preços dos imóveis que um ambiente menos atraente (LUTTIK, 2000).

Shapores et. al. (2012) analisa o efeito da arborização e de espaços urbanos verdes (parques, cemitérios, golfe, lagos e rios) sobre o valor dos imóveis unifamiliares vendidos em 2003 e 2004 na cidade de Los Angeles, EUA. O estudo fornece uma análise abrangente dos benefícios captados pelo mercado imobiliário de espaços urbanos verdes. Os resultados econtrados foram que as árvores adicionais e áreas gramíneas têm diferentes impactos sobre o valor das casas unifamiliares no nível de lote ou bairro. 0 aumento de $1 \%$ na atual cobertura arbórea de uma propriedade padrão resultaria em um ínfimo ganho para seu proprietário (sem levar em conta os custos de manutenção), enquanto o aumento da cobertura na vizinhança (seja em terras públicas ou em propriedades privadas nas proximidades) beneficiaria ligeiramente propriedades mais próximas (SHAPORES et. al., 2012).

Os autores tomam como hipótese que o valor dos imóveis dependem da área do terreno, densidade populacional, níveis de renda, qualidade de escolas, taxa de criminalidade, faixa etária do bairro, bem como composição étnica. Por exemplo, a presença de árvores na vizinhança ou a grama irrigada é provavelmente mais valiosa em uma área densa do que em áreas menos densas com lotes maiores, pois estas características tendem a atenuar externalidades negativas como o ruído. 0 modelo elaborado também leva em consideração a distância a componentes de infraestrutura urbana verde (parques, campos de golfe, lagos, rios e cemitérios). Uma vez que Los Angeles é uma cidade policêntrica, foram incluídas medidas de distância para um distrito comercial central (CBD). Contudo, os melhores esforços de coleta de dados não podem escapar da ameaça de viés variável omitido. Variáveis omitidas (ou inobserváveis) podem ser espacialmente correlacionadas e criar autocorrelação espacial em termos de erro dos modelos hedônicos; exemplos incluem o clima local ou qualidade do bairro (SHAPORES et. al., 2012).

Tanto para o aumento de vegetação no nível de propriedade unifamiliar como para o nível de quarteirão, os benefícios dessa melhoria ambiental é sentido na maioria das famílias em Los Angeles, segundo o estudo de Shapores et. al. (2013). Por outro lado, apesar dos proprietários de imóveis em Los Angeles possam gostar 
de mais árvores em sua vizinhança, eles não estão dispostos a arcar com estes custos. 0 plantio de árvores também poderia acontecer em terrenos públicos, porém a questão do financiamento deste custo adicional no orçamento público parece ser uma barreira. Os autores levantam a questão sobre os mecanismos de financiamento para o fornecimento de bens públicos locais como áreas verdes urbanas, com a possibilidade da criação de tributos e a aceitação da população local para esses custos adicionais, principalmente em época de crise econômica (SHAPORES et. al., 2012).

\subsection{DESCRICÃO METODOLÓGICA}

O modelo de preços hedônicos foi usado para a valoração econômica ambiental da área protegida, o Parque do Poeta, e utilizou-se um bem complementar para efetuar esta mensuração. No caso específico do estudo, o valor da área protegida é observado a partir da qualidade ambiental oferecida ao bem complementar considerado, o bem habitação. Esta qualidade é interpretada com uma característica ambiental do bem habitação, comercializado em um mercado, e representado pela função $z=\left(z_{1}, z_{2}, \ldots, z_{\mathrm{n}}\right)$. Onde segundo Rosen (1974), os componentes de $z,\left(z_{1}, z_{2}, \ldots, z_{\mathrm{n}}\right)$, podem ser mensurados objetivamente e representam nestes valores as percepções dos consumidores de habitação com relação as quantidades das características incorporadas, como a qualidade ambiental. Neste caso, Rosen (1974) aponta que o pressuposto contido neste modelo é que uma quantidade grande das características do bem habitação estão disponíveis para a escolha entre várias combinações possíveis dos componentes $\mathrm{z}_{\mathrm{i}}$ do bem z. Ou seja, existe uma hipotética "cesta de produtos" entre as características dos imóveis e todos os outros produtos possíveis de consumo, $\mathrm{x}$, no qual podem ser feitas escolhas. Obviamente, essa suposição nem sempre é válida, sendo em algumas situações melhor em alguns mercados do que em outros.

No caso da pesquisa realizada, as características z do bem habitação foram separadas em três grandes grupos de atributos, da mesma forma que consta na NBR 14653-6/2008 (Avaliação de Bens - Parte6: Recursos Naturais e ambientais). As características estruturais $\left(\mathrm{R}_{\mathrm{i}}\right)$, características ambientais $\left(\mathrm{A}_{\mathrm{i}}\right)$ e características socioeconômicas da região $\left(\mathrm{SE}_{\mathrm{i}}\right)$. Segundo a referida norma, a função de preços hedônicos que será mensurada para o bem ambiental, utilizará "características 
quantificáveis que expressam indiretamente a disposição a pagar ou a receber pelo recurso ambiental e sua influência específica no preço do bem (Pi)". O bem referido será o bem habitação e a expressão geral da função que relaciona o preço do bem $(\mathrm{Pi})$ às suas características, será expressa por:

$$
P_{i}=P\left(R_{i}, A_{i}, S E_{i}\right)
$$

Equação 2

Estas caraterísticas foram ainda divididas em outros vários atributos para o tipo específico de habitação adotado como recorte da pesquisa, os residenciais multifamiliares com elevador (apartamentos com elevador). A escolha desta tipologia se deu devido a própria estrutura deste topo de moradia, que torna mais fácil a observação do ambiente natural para o habitante, podendo ele usufruir de uma vista cênica mais apreciável. Neste caso, os efeitos externos causados pela violência urbana são atenuados, não causando muita influência na escolha locacional do indivíduo. Para as caraterísticas estruturais foram então inicialmente consideradas as variáveis: andar, área privada, número de banheiros, estado de conservação, garagem, idade, padrão construtivo, número de quartos e número de suítes. Para as características ambientais foram consideradas: distância ao açude velho, distâcia à área protegida, distância ao centro, distância ao parque da criança e distância ao shopping. Já para as variáveis sócioeconômicas utilizou-se a variável de renda média dos chefes de família por bairro.

Uma das características mais comuns que acontece com o consumidor de habitação é a busca pelo o máximo de satisfação possível com o bem consumido. Na teoria econômica, isso aparece como um problema da maximização da utilidade do consumidor. Na maximização da utilidade do consumidor do bem habitação, assume-se alguns pressupostos como o de que bem diferenciado, ou seja o bem representado pela função $z=\left(z_{1}, z_{2}, \ldots, z_{n}\right)$, seja vendido em um mercado perfeitamente competitivo e as interações entre produtores e consumidores conduzam a uma situação chamada de ponto ótimo do preço de equilíbrio. Com isso, a utilidade do consumidor de habitação é definida em dois bens: z, o bem diferenciado que inclui as suas características ambientais, e x, uma mercadoria composta que representa todas as outras mercadorias (ou seja, a renda restante após a compra z). 0 consumidor j, com características demográficas $\alpha^{j}$, tem então sua utilidade definida como: 


$$
U^{j}\left(x, z_{1}, z_{2}, \ldots, z_{n} ; \alpha^{j}\right)
$$

\section{Equação 3}

Segundo Taylor (2003), o consumidor hipotético j vai procurar maximizar a utilidade, escolhendo o bem diferenciado, $\mathrm{z}$, e a quantidade de unidades de $\mathrm{x}$, sendo sujeito a uma restrição orçamentária $\mathrm{y}^{\mathrm{j}}=\mathrm{x}+\mathrm{P}(\mathrm{z})$, onde $\mathrm{y}$ vai ser sua renda, $\mathrm{x} a$ quantidade consumida de todos os outros bens e $\mathrm{P}(\mathrm{Z})$ o bem diferenciado considerado, o bem habitação que inclui todas as suas características. Neste caso, o consumidor optará pela cesta de bem $(\mathrm{z} ; \mathrm{x})$ onde a seguinte situação é satisfeita para cada atributo $\mathrm{Z}_{\mathrm{i}}$ :

$$
\frac{\partial P}{\partial z_{i}}=\frac{\partial U / \partial z_{i}}{\partial U / \partial x}
$$

\section{Equação 4}

que nos informa a taxa marginal de substituição (TMS) entre qualquer característica, $\mathrm{z}_{\mathrm{i}}$, e o bem composto, $\mathrm{x}$. Para a característica de interesse, a qualidade ambiental do Parque do Poeta, optou-se por mensurar sua quantidade através da distância ao parque. Nisto, supõe-se que está incluso toda a percepção que as pessoas tem com respeito aos bens e serviços ambientais oferecidos pela área protegida do estudo. Esta suposição pode parecer frágil aparentemente, porém precisamos entender que a maior parte dos indíviduos que fazem escolhas de moradia não levam em consideração aspectos detalhados de todos os serviços possíveis oferecidos pelo ecossistema, como mostrado na Tabela 1. Entretanto, eles podem levar em consideração aspectos mais gerais sobre o ambiente, incluindo por exemplo em sua tomada de decisão uma ideia sobre a melhoria do ar em uma região arborizada ou aumento de qualidade de vida quando é possível usufruir de espaços verdes de recreação e contato com a natureza. Todos esses aspectos podem ser classificados enquanto serviços de regulação do ar, serviços de regulação do clima e serviços culturais e foram generalizados nesta pesquisa como uma característica de qualidade ambiental, que aumenta na medida em que a moradia se aproxima da área protegida.

Segundo a NBR 14653-6/2008, esta medição do valor econômico dos bens e serviços ambientais pelo método de preços hedônicos só consegue captar os valores de uso (VUD, VUI e VO) destes bens, isto é feito a partir da Equação 5. Nesta pesquisa, 
este valor implícito da qualidade ambiental da área protegida foi mensurado pela seguinte função:

$$
D A P m=\frac{\partial P}{\partial D i s t}
$$

\section{Equação 5}

onde o DAPm é a disposição marginal a pagar pelo atributo de distância à área protegida e é mensurada pelo cálculo da primeira derivada parcial da função de preços hedônicos de apartamentos com elevador em Campina Grande pela variável distância à área protegida. A interpretação desta relação se dar do mesmo modo da taxa marginal de substituição que vai informar o quanto que o consumidor de apartamentos em Campina Grande - PB está disposto a trocar unidades monetárias pela proximidade com uma área verde, ou seja pelo aumento da qualidade ambiental.

A formulação mais simples da equação de preços hedônicos, relacionada com o comportamento do mercado habitacional, é representada por:

$$
Y_{i}=\beta_{0}+\beta_{1} X_{i 1}+\beta_{2} X_{i 2}+\ldots+\beta_{k} X_{i k}+\varepsilon_{i}, i=1, \ldots, m .
$$

\section{Equação 6}

onde: $\mathrm{Y}_{1}, \ldots, \mathrm{Y}_{\mathrm{m}}$ - chama-se variável dependente, representada pelo preço da

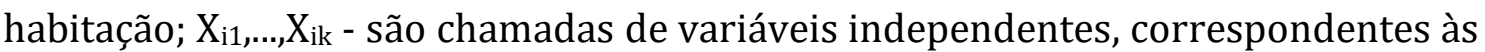
já citadas características estruturais, ambientais e os aspectos socioeconômicos. $\beta_{0, \ldots,} \beta_{\mathrm{k}}$ são denominados de parâmetros do modelo e $\varepsilon_{1}, \ldots, \varepsilon_{\mathrm{m}}$ são os erros aleatórios, que não podem ser explicados por características explícitas, refletindo a dinâmica aleatória do comportamento humano. A estimação dos parâmetros populacionais $(\beta)$ será calculada por meio de inferência estatística, utilizando-se de uma amostra coletada, que consiste na minimização da soma dos quadrados das distâncias, medidas na vertical, entre os preços observados no mercado e os ajustados pelo modelo adotado (DANTAS,2003). 


\section{GAPITULO V}

\section{RESULTADOS E ANÁLISES}

Os dados usados na pesquisa foram obtidos em parceria com a empresa de avaliações e perícias em engenharia Proxy Engenharia Ltda que atua em Campina Grande - PB e região desde 2011. A amostra obtida foi de 240 dados de oferta e de vendas para imóveis do tipo apartamento com elevador em vinte bairros da cidade entre os anos de 2015 a 2020. Na Figura 4, os apartamentos foram alocados no mapa do município de Campina Grande. Os diferentes tipos de hachuras separam os bairros e suas respectivas rendas médias (IBGE, 2010). As variáveis usadas foram divididas em dois tipos: variáveis endôgenas e exôgenas. As endôgenas foram obtidas a partir de dados do mercado imobiliário atráves das corretoras de imóveis. A medição das variáveis exôgenas foram obtidas por meio de instrumentos oferecidos pelo software Google Earth Pro. Na pesquisa utilizou-se a linguagem R, como ferramenta, para fazer as análises de regressão e a construção dos gráficos. ${ }^{1}$.

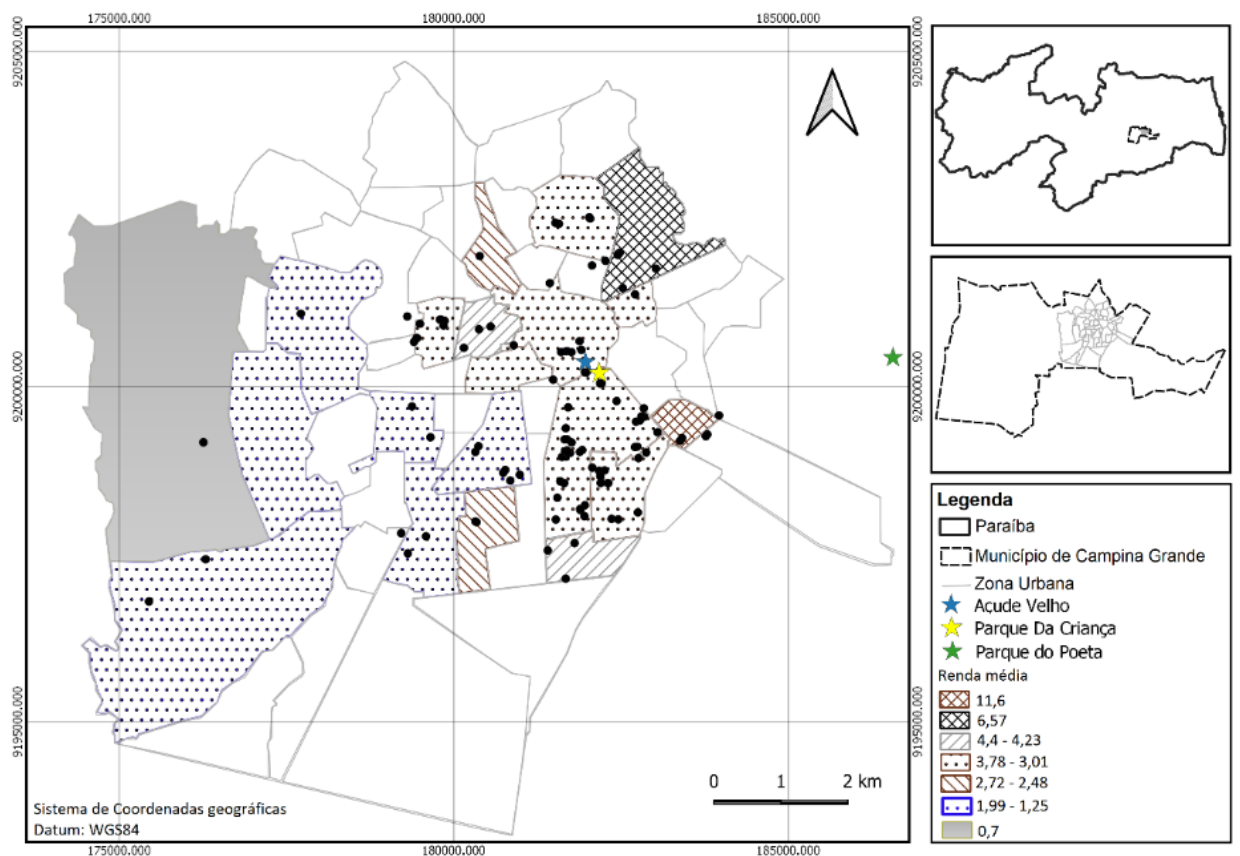

Figura 4 - Dados de apartamentos geolocalizados no município de Campina Grande -PB. Fonte: Erimagna de Morais Rodrigues (2021).

${ }^{1}$ O R é um ambiente para computação e análise estatística, que possui uma linguagem de programação própria. Para realizar suas atividades no R, você escreve comandos que estão semanticamente de acordo com as regras e padrões dessa linguagem (FARIA e PARGA, 2020). 


\subsection{ANÁLISE EXPLORATÓRIA DOS DADOS}

\subsubsection{GRÁFICO BOXPLOT}

No processo de análise exploratória dos dados da pesquisa, optou-se pela escolha do gráfico de boxplot para observar a variável valor do imóvel em cada bairro da cidade. 0 boxplot é um tipo de gráfico usado na análise exploratória de dados e sua construção é possível por meio de qualquer software estatístico. Através dele é possível identificar tendência central não-paramétrica (mediana), dispersão (quartis 25\% e 75\%), forma de distribuição ou simetria da amostra (valores pontuais mínimo e máximo), valores atípicos (outliers) e extremos.

O formato de "caixa e haste" é comum em qualquer gráfico boxplot, tanto em orientação horizontal ou vertical (Figura 5). As informações mostradas em um boxplot com disposição vertical são as seguintes:

i. Eixo vertical: variável quantitativa;

ii. Eixo horizontal: fator de interesse;

iii. Primeiro quartil (Q1): onde se localiza 25\% dos menores valores da amostra. Linha do limite inferior da caixa no gráfico;

iv. Mediana ou segundo quartil (Q2): onde se localiza 50\% dos dados da amostra. Linha de dentro da caixa;

v. Terceiro quartil (Q3): onde se localiza 75\% dos dados da amostra. Linha do limite superior da caixa;

vi. Intervalo interquartílico (Q3 - Q1 ou IIQ): diferença entre Q3 e Q1. No gráfico é representado pela dimensão da caixa.

vii. Limite inferior $\left(\mathrm{L}_{\mathrm{i}}\right)$ : é calculado por Q1 - 1,5 (Q3-Q1), excluindo os outliers e/ou extremos;

viii. Limite superior $\left(\mathrm{L}_{\mathrm{s}}\right)$ : é calculado por Q3 + 1,5 (Q3-Q1), excluindo os outliers e/ou extremos;

ix. Outliers (valores atípicos): valores acima e/ou abaixo de 1,5 vezes do IIQ;

X. Extremos: valores acima e/ou abaixo de 2,5 vezes o IIQ (duas vezes e meia o intervalo interquartílico). 


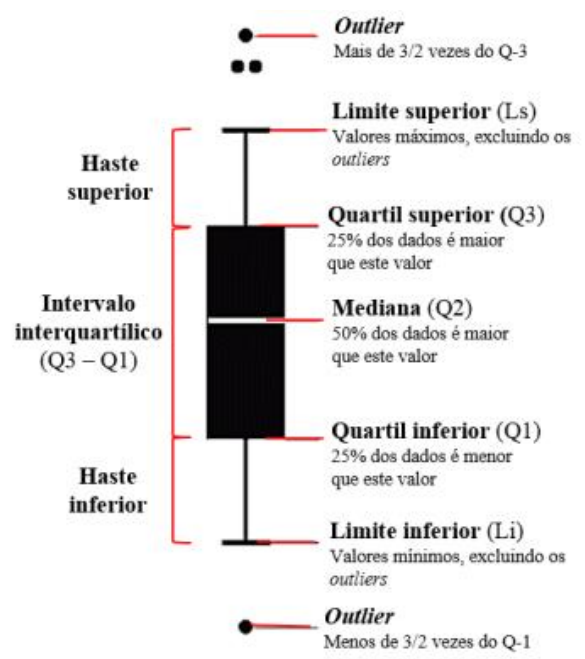

Figura 5- Descrição das partes de um boxplot.

Fonte: Google, 2021.

O gráfico boxplot foi construído a partir da amostra de dados da pesquisa, utilizando-se do pacote ggplot2 da linguagem R. A variável quantitativa usada para a construção do gráfico foi o valor do imóvel, observado para o fator de interesse bairro. 0 resultado é mostrado na Figura 6. Com a observação do gráfico pode-se perceber que nos bairros Catolé, Centro, Cruzeiro, Jardim Tavares, Prata e Sandra Cavalcante existem outliers. Desta forma, buscou-se identificar esses dados, foi utilizando-se o pacote dplyr, e optou-se por eliminá-los do banco de dados para melhor construção do modelo de regressão linear. Pois, os outliers geralmente geram modelos imprecisos e tendeciosos.

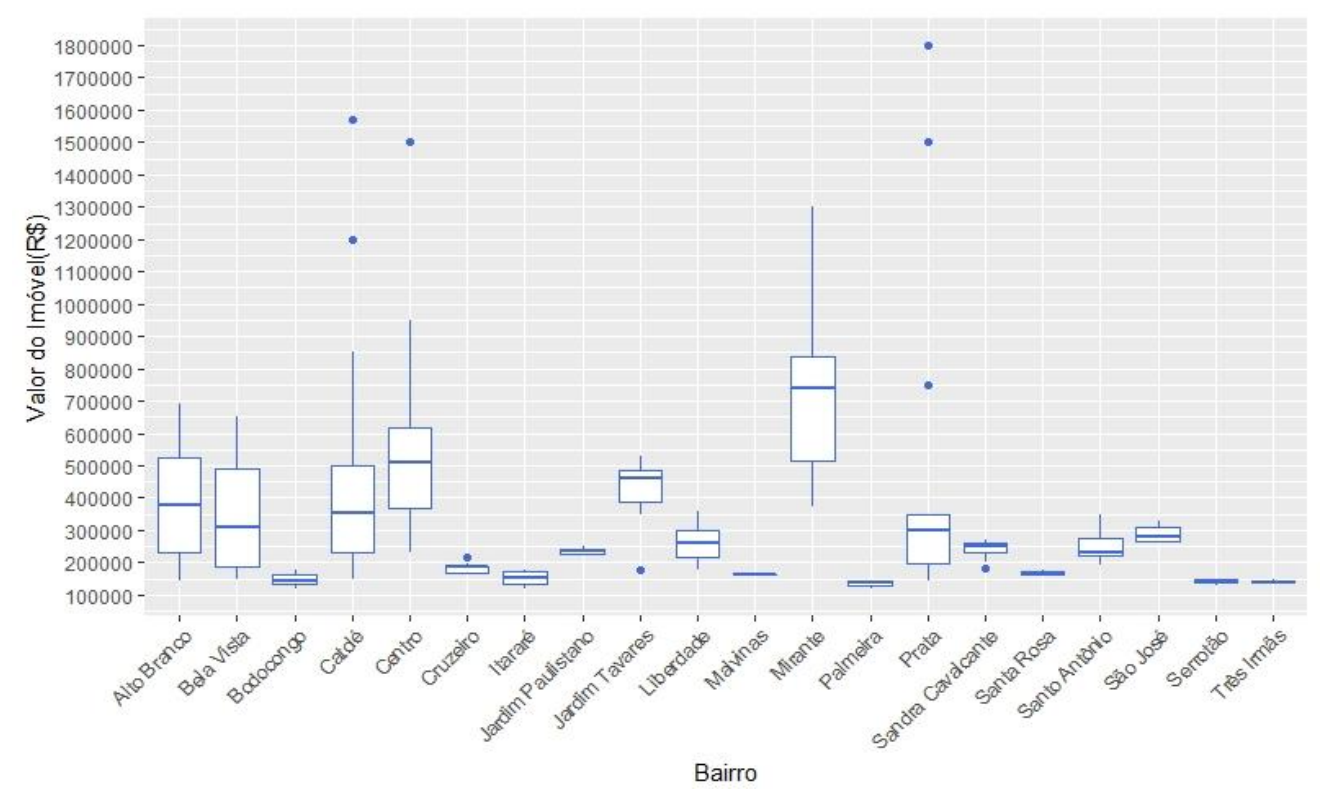

Figura 6- Gráfico boxplot para valor do imóvel por bairros de Campina Grande-PB. Fonte: Elaboração própria. 


\subsubsection{MATRIZ DE CORRELAÇÃO}

Neste trabalho foi usado o coeficiente de correlação de Pearson (1920) para verificar o grau de asscoiação linear entre as variáveis do estudo. A correlação é um número que varia entre -1 e 1 . A letra $\mathrm{r}$ representa a correlação, entre as variáveis, calculada pela equação:

$$
r=\frac{\sum\left(x_{i}-\bar{x}\right)\left(y_{i}-\bar{y}\right)}{\sqrt{\sum\left(x_{i}-\bar{x}\right)^{2} \sum\left(y_{i}-\bar{y}\right)^{2}}}
$$

Equação 7

Uma matriz de correlação é uma tabela mostrando o coeficiente de correlação entre as variáveis explicativas (Xi) e a variável explicada (Yi), no modelo em estudo. Cada célula na tabela mostra a correlação entre duas variáveis. A correlação pode ser positiva $(r>0)$, o que significa que quando uma variável está aumentando a outra também está aumentando ou negativa $(\mathrm{r}<0)$ quando uma está aumentando a outra está diminuindo. A correlação também pode ser nula ou zero, o que significa que as variáveis não estão relacionadas. A tabela 2 indica os níveis de correlação entre as variáveis, variando de nula, fraca, média, forte, fortíssima a perfeita.

Tabela 2 - Níveis de correlação entre as variáveis.

$\left|\begin{array}{cc}\text { Coeficiente } & \text { Correlação } \\ |r|=0 & \text { nula } \\ 0<|r| \leq 0,30 & \text { fraca } \\ 0,30<|r| \leq 0,70 & \text { média } \\ 0,70<|r| \leq 0,90 & \text { forte } \\ 0,90<|r| \leq 0,99 & \text { fortíssima } \\ |r|=1 & \text { perfeita }\end{array}\right|$

Para a pesquisa, foi calculada a matriz de correlação entre as variáveis númericas da amostra escolhida, o resultado encontra-se na Figura 7. A escolha das variáveis é um processo importante para a construção do modelo. Sendo assim, a partir dos resultados encontrados pela criação da matriz de correlação foram selecionadas as variáveis que foram usadas na modelagem, sendo o critério para tal 
seleção, o valor do coeficiente pearson de correlação com o valor do imóvel estando no nível de: médio, forte ou fortíssimo. Os resultados mostram que as variáveis correlacionadas com o valor do imóvel em nível forte ou fortíssima são: banheiros, área privativa, vagas de garagem, padrão construtivo e quantidade de suítes. As varíaveis que estão em nível médio são: andar, distância ao açude velho, distância ao parque da criança, distância ao shopping e distância da área protegida, renda média e quantidade de quartos.

Uma das premissas para o uso do MQO no cálculo dos parâmetros estimados é de que as variáveis independentes não devem possuir nenhuma relação linear entre elas. Com isso, o uso da matriz de correlação pode ajudar na indentificação destas relações. Desta forma, observa-se a partir da Figura 6 que existe forte correlação nas variáveis independentes de distância ao açude, distância ao centro, distância ao parque da criança, distância ao shopping e distância à área protegida. Neste caso, dentre as variáveis que envolve características do ambiente, optou-se por trabalhar apenas com a variável de interesse para o estudo, que é a distância à área protegida, para evitar problemas de multicolinearidade no modelo de regressão construído. No mesmo sentido, as variáveis independentes número de suítes, número de banheiros e vagas de garagem também apresentam forte correlação e então optou-se por manter a variável número de suítes.

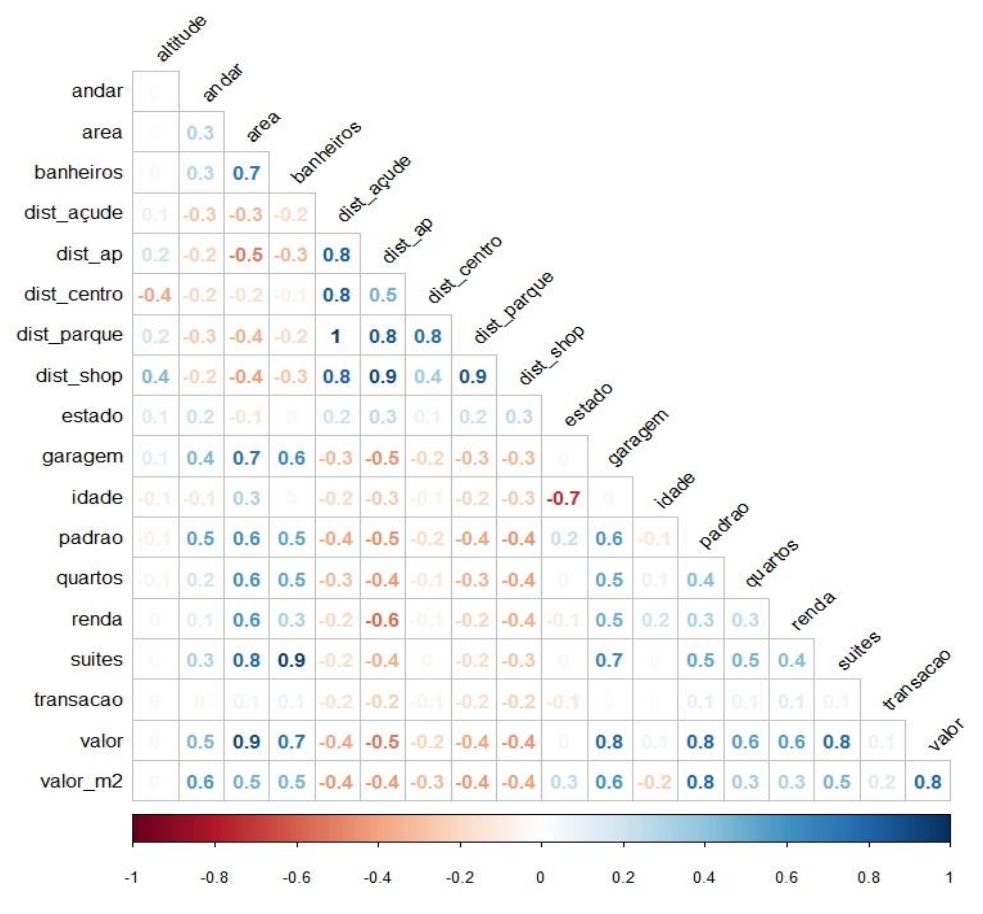


Figura 7- Matriz de correlações.

Fonte: Elaboração própria.

\section{1.3. DIAGRAMA DE DISPERSÃO}

O gráfico de diagrama de dispersão é importante para observar a relação da variável dependente com as respectivas variáveis independentes em um plano cartesiano com duas dimensões. No mais, é possível identifcar se houve alguma extrapolação das variáveis independentes em relação as variáveis depententes ou identificar a tendência linear entre elas. No estudo em questão foi realizada a construção do gráfico de dispersão (Figura 8) para as varíaveis endôgenas (Eixo X) área, número de quartos, padrão construtivo1, andar, número de suítes e exôgena distância à área protegida.
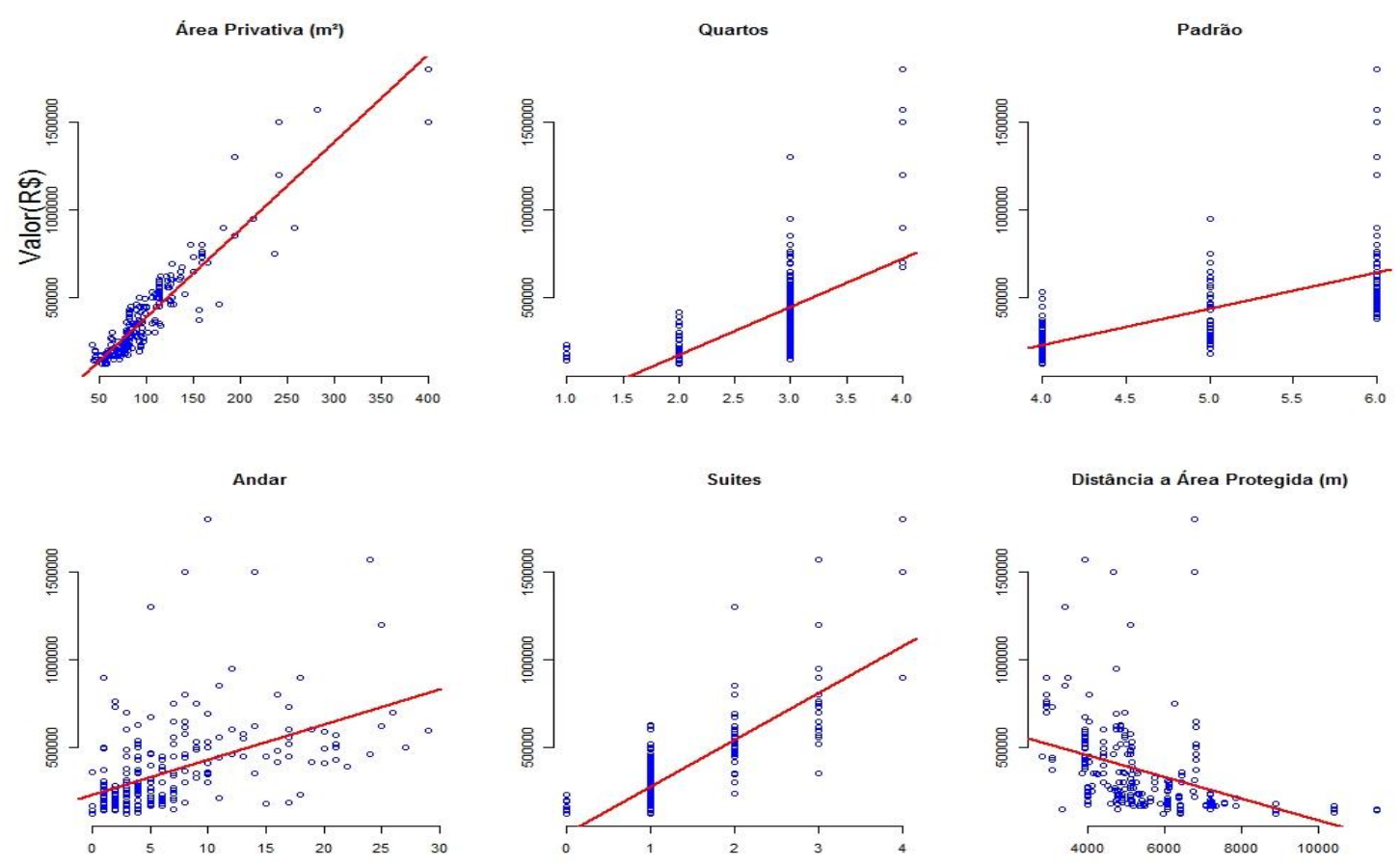

Figura 8- Diagramas de dispersão.

Fonte: Elaboração própria.

Através da Figura 8, percebe-se que as variáveis endôgenas tem uma tendência crescente na medida em que suas características crescem. Ou seja, quanto

${ }^{1}$ NORMAL BAIXO (03): Intermediário entre baixo e normal.

NORMAL (04): PISOS - Cerâmica de primeira linha látex; PAREDES - Látex; FORRO - Látex; ACESSORIOS - Primeira linha em ferragens (deca, docol, fabrimar) e louças.

NORMAL/ALTO (05): Intermediário entre normal e alto.

ALTO (06): PISOS - Porcelanato polido, granito, pedras ou cerâmicas diferenciadas; PAREDES Revestimentos diferenciados aplicação parcial painéis em textura trabalhada; FORRO - Projeto decorativo personalizado; ACESSORIOS - Louças e metais de luxo. 
maior a área, número de quartos, a melhoria do padrão construtivo e o andar do imóvel maior será o seu valor. Este comportamento pode ser observado intuitivamente no mercado imobiliário. Com relação à forma da curva, verifica-se que a variável área tem características próximas a linearidade, enquanto que andar não apresenta aparentemente uma forma clara. Da mesma forma, observa-se que a dispersão é maior para andar do que para a área o que indica um comportamento linear entre a relação das variáves.

Para a variável exôgena distância à área protegida, percebe-se uma tendência decrescente com o aumento desta variável, ao contrário das variáveis endôgenas, quanto menor a distânca à área protegida maior será o valor, uma relação inversamente proporcional. Entretanto, da mesma forma da variável andar, a dispersão é alta principalmente para imóveis mais próximos à área protegida, o que nos dar um indício de uma variância não constante para a variável.

\subsection{MODELO DE REGRESSÃO LINEAR CLÁSSICO}

Um modelo de regressão linear se caracteriza pela possibilidade de encontrar relações lineares aproximadas entre duas ou mais variáveis ${ }^{1}$. A partir dele, pode-se fazer conclusões sobre fatores envolvidos em fenômenos que não são observados diretamente na realidade. Neste caso, os parâmetros populacionais $\beta$ são inferidos a partir de uma dada amostra usando o chamado método dos mínimos quadrados ordinários (MQO). A equação que surge representa um espelho do fenômeno em estudo e com ela podemos encontrar as relações entre as variáveis. No estudo em questão, a variável dependente considerada foi o valor do imóvel $\left(\mathrm{Y}_{1}, \ldots, \mathrm{Y}_{\mathrm{m}}\right)$ e as variáveis indepententes classificadas em: variáveis endôgenas e exôgenas $\left(\mathrm{X}_{\mathrm{i} 1}, \ldots, \mathrm{X}_{\mathrm{ik}}\right)$. Com isso, a equação do modelo calculada (Equação 8), utilizando o banco de dados citado, para a função de preços hedônicos foi:

VALOR $=-346.100,00+3.806,00 *$ ÁREA $-3.822,00 *$ № QUARTOS + 32.360,00*№ SUÍTES + $63.530,00 *$ PADRÃO + 3.107,00*ANDAR - 0,45*DIST. ÁREA PROTEGIDA

Equação 8

Para que estes parâmetros calculados $\left(\beta_{\mathrm{k}}\right)$ sejam não-tendenciosos, eficientes e consistentes, assume-se alguns pressupostos sobre as variáveis

\footnotetext{
${ }^{1}$ Segundo Gujarati (2011) o termo linear usado na expressão "regressão linear" significa uma característica linear dos parâmetros e não das variáveis; os $\beta$ (isto é, os parâmetros) são elevados apenas à primeira potência. Neste caso as variáveis dependentes, os X, podem ou não ser lineares.
} 


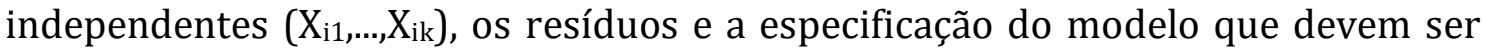
atendidos. 0 primeiro deles é que as variáveis independentes não devem conter nenhuma perturbação aleatória e nenhuma relação linear entre elas. 0 segundo é que os resíduos devem satisfazer as hipóteses de variância constante, normalidade e ausência de autocorrelação. E por último o de que na composição do modelo estejam incluídas apenas variáveis independetes significativas, assim como as escalas das variáveis sejam escolhidas de modo a garantir a linearidade do modelo (DANTAS, 2003).

Tabela 3 - Resultados da regressão para o Modelo 1.

\begin{tabular}{|c|c|c|c|}
\hline & Coeficientes & Erro Padrão & p-valor \\
\hline Intercepto & $-346.100,00$ & 49850,00 & $<0,05$ \\
\hline Área $\left(\mathrm{m}^{2}\right)$ & $3.806,00$ & 183,00 & $<0,05$ \\
\hline № Quartos & $-3.816,00$ & 11460,00 & 0,7393700 \\
\hline № Suítes & $32.360,00$ & 10530,00 & $<0,05$ \\
\hline Padrão & $63.530,00$ & 8099,00 & $<0,05$ \\
\hline Andar & $3.107,00$ & 969,80 & $<0,05$ \\
\hline Dist. Área Protegida (m) & $-0,45$ & 3,57 & 0,9007200 \\
\hline Observações & & & 233 \\
\hline $\mathrm{R}^{2}$ & & & 0,919 \\
\hline $\mathrm{R}^{2}$ ajustado & & & 0,917 \\
\hline Erro padrão residual & & & 73997,91 \\
\hline Estatística F & & & 427,20 \\
\hline P-valor & & & $<0,05$ \\
\hline
\end{tabular}

Fonte: Elaboração própria.

A partir da análise do modelo calculado (Tabela 3) percebe-se que existem alguns problemas em sua capacidade de explicação do fenômeno estudado. Observa-se que o intercepto da função (Constant) é - 346.100,00, indicando o valor do imóvel esperado médio caso as demais variáveis da equação sejam nulas. Este resultado em si mostra-se incoerente com a realidade do mercado imobiliário, pois no mesmo não existe a possiblidade de algum valor estar dentro do conjunto numérico dos reais negativos. Ademais, observa-se que cada vez que se distancia $1 \mathrm{~m}$ da área protegida o valor do imóvel diminui em 0,45 reais. Entretanto, na quarta 
coluna da Tabela 3 que mostra os valores do p-valor ${ }^{1}$, o teste estatístico usado mostra que na variável distância à área protegida a hipótese nula $\left(\mathrm{H}_{0}\right.$ : a distância à área protegida não é importante na formação do preço do imóvel; Ha: a distância à área protegida é importante para formação do preço) não pode ser rejeitada e isto implica que provavelmente o parâmetro da variável é igual a zero, não sendo assim estatisticamente signficativo para explicar a variação do valor.

Para avaliar o poder de explicação do modelo de regressão múltipla utilizouse o coeficiente de determinação ajustado ( $\mathrm{R}^{2}$ ajustado). Este coeficiente expressa o poder de explicação para o modelo em função das variáveis independetes consideradas. Ele é calculado usando a Equação 9. Para o modelo calculado o valor deste coeficiente é 0,917 , o que nos diz que 91,7\% na variabilidade observada nos preços pode ser explicada pelas variáveis indepentendes escolhidas.

$$
\bar{R}=1-(1-R) \frac{n-1}{n-k-1}
$$

\section{Equação 9}

Com relação aos resíduos do modelo calculado, construiu-se o gráfico dos valores ajustados (Fitted Values) pelos resíduos (Residual) a fim de verificar a hipótese de homocedasticidade (Figura 9). No gráfico, percebe-se que existe uma concentração de pontos mais à esquerda, indicando uma heterogeneidade da variância. $\mathrm{O}$ que nos dar indícios de que a hipótese da homocedasticidade não está sendo atendida para esse modelo. Outra forma usada para verificar o não atendimento da hipótese de homocedasticidade, ou seja a heterocedasticidade do modelo, foi através do teste estatístico de Breusch Pagan ${ }^{2}$. A probablidade calculada foi de 3,576222*10-69, sendo menor que o nível de signifcância adotado de 5\%. Neste caso, a hipótese nula $\mathrm{H}_{0}$ é rejeitada e assume-se a hipótese alternativa $\mathrm{H}_{\mathrm{a}}$ que afirma que a variância provavelmente não é constante.

\footnotetext{
10 p-valor é uma probabilidade final que tem grande impacto em testes estatísticos. Significa o mínimo valor para o qual a hipótese nula ainda seria rejeitada. É definida como a probabilidade, sob a hipótese nula, de encontrar uma estatística de teste (em valores absolutos) que exceda o valor da estatística que foi calculada a partir da amostra. Assim, se o p-valor é menor do que o nível de significância $\alpha$, rejeita-se a hipótese nula (Wooldridge, 2013).

20 Teste de Breusch Pagan foi introduzido por Trevor Breusch e Adrian Pagan em 1979. É usado para testar a heteroscedasticidade em um modelo de regressão linear. A hipóteses usadas no teste são: Hipótese nula (H0): Os resíudos são Homoscedástico (ou seja, pode-se concluir que a variança dos resíduos é constante); Hipótese alternativa (Ha): Os resíduos são Heteroscedástico (a variança dos resíduos não é constante). Se o valor p do teste for inferior a algum nível de significância (o nível adotado foi $\alpha=5 \%$ ), então rejeitamos a hipótese nula e concluímos que a heterocedasticidade está presente no modelo de regressão.
} 


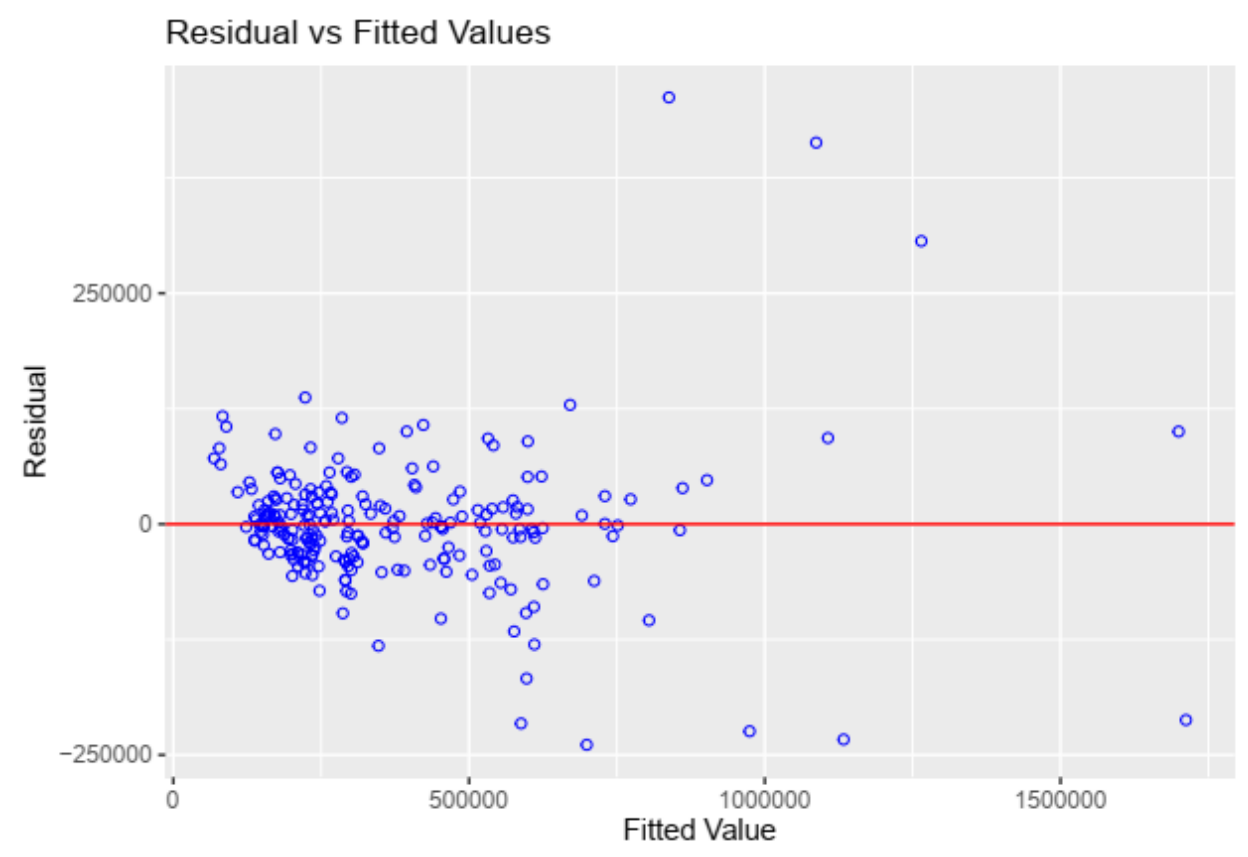

Figura 9- Gráfico dos resíduos padronizados versus valores ajustados do modelo 1. Fonte: Elaboração própria.

A outra hipótese assumida para os resíduos do modelo é a de normalidade. Para a verificação desta, utilizou-se inicialmente a observação do gráfico Q-Q plot, que detecta o pressuposto de normalidade (Figura 10). Como se ver, os quantis da distribuição de probabilidade dos resíduos não estão alinhados de forma totalmente linear como na linha vermelha do gráfico. 0 que nos dar indícios da não-normalidade dos resíduos do modelo. Outra forma utilizada para detectação da normalidade dos resíduos foi através dos testes estatísticos: Shapiro-Wilk e Kolmogorov-Smirnov. Nos dois testes os p-valores são menores que 5\%, assim sendo, rejeitamos a hipótese de normalidade dos resíduos. Assim, para um nível de confiança de 95\%, temos evidências de que os resíduos não seguem uma distribuição normal. 


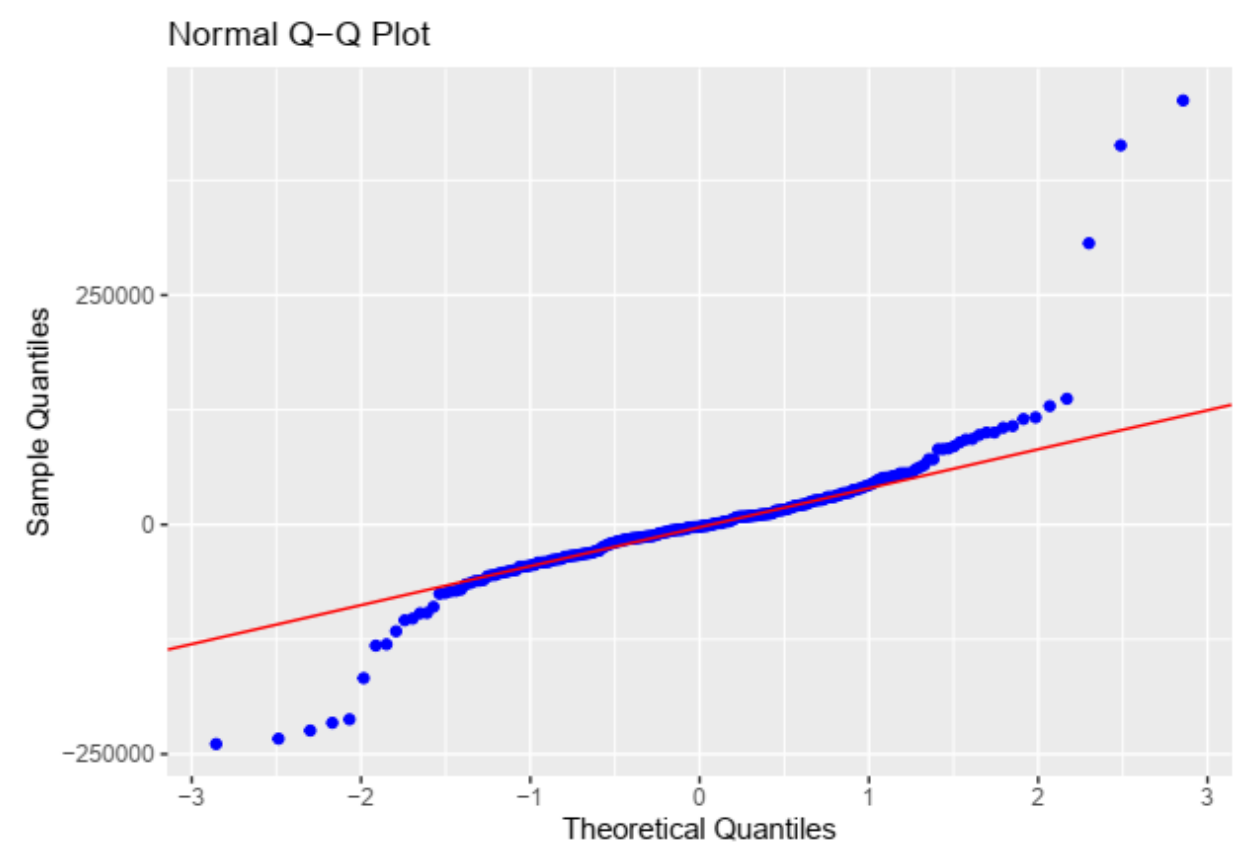

Figura 10- Gráfico Normal Q-Q plot do modelo 1.

Fonte: Elaboração própria.

Para a hipótese de ausência de auto-correlação entre os resíduos utilizou-se a observação do gráfico de resíduos versus valores ajustados (Figura 9) e o teste estatístico de Durbin-Watson. Este teste é usado para detectar a presença de autocorrelação nos resíduos de uma regressão, utilizando as seguintes hipóteses: $\mathrm{H}_{0}$ para a hipótese de que não existe auto-correlação entre os resíduos e $\mathrm{H}_{\mathrm{a}}$ para o caso em que existe auto-correlação entre os resíduos. 0 resultado encontrado para a probabilidade p-valor foi de 0,1179. Como o resultado foi maior do que 0,05 aceitamos a hipótese nula de que não existe auto-correlação, sendo aceita a premissa de ausência de auto-correlação necessária para a escolha de um modelo de regressão não-tendencioso, eficiente e consistente.

Segundo Dantas (2003) a falta de normalidade é comum nos preços de imóveis, pois eles estão inseridos no campo dos reais positivos, enquanto que a distribuição normal abrange todos os números reais. Com relação à heterocedasticidade, para o autor é natural que ocorra nos dados de bens imobiliários, devido à variabilidade da restrição orçamentária dos consumidores desse bem, de forma a produzir uma tendência de maior dispersão para os maiores preços do que para os menores. Para atenuar esse problema, o autor sugere que a transformação log (transformação logarítmica na base neperiana) nos preços pode ser suficiente para estabilizar a variância e normalizar os resíduos. Outro aspecto 
importante considerado por Dantas (2012) sobre a transformação logarítmica nos modelos de valores imobiliários diz respeito à possibilidade de o deixar multiplicativo, característica sujerida pelas normas técnicas brasileiras que tratam da avaliação de bens (NBR: 14653-6/2006).

A partir da análise do novo modelo calculado (Tabela 4) pode-se constatar algumas mudanças ocorridas em relação ao Modelo 1. 0 intercepto da função (Constant) está com o sinal positivo e as relações das variáveis independentes com a dependente estão coerentes com o observado nos gráficos de dispersão (Figura 8). Entretanto, a variável número de quartos não é estatisticamente significativa (pvalor $>0,05)$. Com isso, optou-se por retirá-la do modelo e recalcular assim um novo modelo de regressão (Equação 10).

Tabela 4- Resultados da regressão para o Modelo 2.

\begin{tabular}{|c|c|c|c|}
\hline & Coeficientes & Erro Padrão & p-valor \\
\hline Intercepto & 8,72 & 0,53 & $<0,05$ \\
\hline $\log ($ Área $)$ & 0,85 & 0,06 & $<0,05$ \\
\hline № Quartos & 0,03 & 0,03 & 0,2106000 \\
\hline № Suítes & 0,06 & 0,02 & $<0,05$ \\
\hline Padrão & 0,18 & 0,02 & $<0,05$ \\
\hline Andar & 0,01 & 0,00 & $<0,05$ \\
\hline log(Dist.Área protegida) & $-0,11$ & 0,05 & $<0,05$ \\
\hline Observações & & & 233 \\
\hline $\mathrm{R}^{2}$ & & & 0,920 \\
\hline $\mathrm{R}^{2}$ ajustado & & & 0,918 \\
\hline Erro padrão residual & & & 0,16 \\
\hline Estatística F & & & 434,60 \\
\hline P-valor & & & $<0,05$ \\
\hline
\end{tabular}

Fonte: Elaboração própria.

Os coeficientes $\beta_{1}$ e $\beta_{5}$ são, nesse novo cenário, as elasticidades do preço dos apartamentos em relação a sua área privativa e a distância à área protegida respectivamente e os coeficientes $\beta_{2}$, $\beta_{3}$ e $\beta_{4}$ são chamados de semi-elasticidades do preço em relação a número de suítes, padrão construtivo e andar (WOOLDRIDGE, 2013). Neste caso, o coeficiente $\beta_{2}$ é a mudança no log do preço quando o número de suítes mudar em uma unidade, $\beta_{3}$ é a mudança no log do preço quando o padrão construtivo alterar de nível e $\beta_{4}$ é a mudança no log do preço quando o andar variar em um pavimento. 
$\log ($ VALOR $)=8,66$ + 0,89* Log(ÁREA $)+0,05 *$ № SUÍTES + 0,18*PADRÃO + 0,01*ANDAR $0,12 * \log$ (DIST. ÁREA PROTEGIDA)

\section{Equação 10}

Segundo Wooldridge (2013) para melhor interpretarmos o modelo calculado, é necessário multiplicarmos os coeficientes em escala linear por 100, e assim teremos a mudança percentual aproximada no preço quando a variável independente é acrescida em 1 unidade. A mudança ocorrida nas variáveis com escala logarítima acontece de forma percentual. Dessa forma, quando a distância à área protegida aumenta em 1\%, o preço dos apartamentos se reduz em 0,12\%, mantendo o resto das variáveis fixas.

Tabela 5 - Resultados da regressão para o Modelo 3.

\begin{tabular}{|c|c|c|c|}
\hline & Coeficientes & Erro Padrão & $\mathrm{p}$-valor \\
\hline Intercepto & 8,66 & 0,53 & $<0,05$ \\
\hline $\log ($ Área $)$ & 0,89 & 0,05 & $<0,05$ \\
\hline № Suítes & 0,05 & 0,02 & $<0,05$ \\
\hline Padrão & 0,18 & 0,02 & $<0,05$ \\
\hline Andar & 0,01 & 0,00 & $<0,05$ \\
\hline $\log$ (Dist. Área Protegida) & $-0,12$ & 0,05 & $<0,05$ \\
\hline Observações & & & 233 \\
\hline $\mathrm{R}^{2}$ & & & 0,919 \\
\hline $\mathrm{R}^{2}$ ajustado & & & 0,918 \\
\hline Erro padrão residual & & & 0,16 \\
\hline Estatística F & & & 434,60 \\
\hline P-valor & & & $<0,05$ \\
\hline
\end{tabular}

Fonte: Elaboração própria.

A partir da Tabela 5, podemos observar que o modelo calculado teve um poder de explicação de aproximadamente 91,8 \% ( $\mathrm{R}^{2}$ ajustado), um pouco melhor do que no primeiro modelo calculado, que foi de 91,7 \% (Tabela 3). Isto se deve, principalmente porque nele estar contido variáveis que são estatisticamente mais importantes para a explicação do valor dos imóveis. Podemos então afirmar com relação ao modelo calculado, que 91,8\% da variação do valor dos apartamentos no estudo podem ser explicados pelas variáveis independentes. Ou seja, a área privativa, o número de suítes, o padrão construtivo, o andar e a distância à área 
protegida podem explicar o valor dos imóveis em 91,8\%. Com isso, tiramos também que $8,2 \%$ da variabilidade nos preços são explicados por outras variáveis.

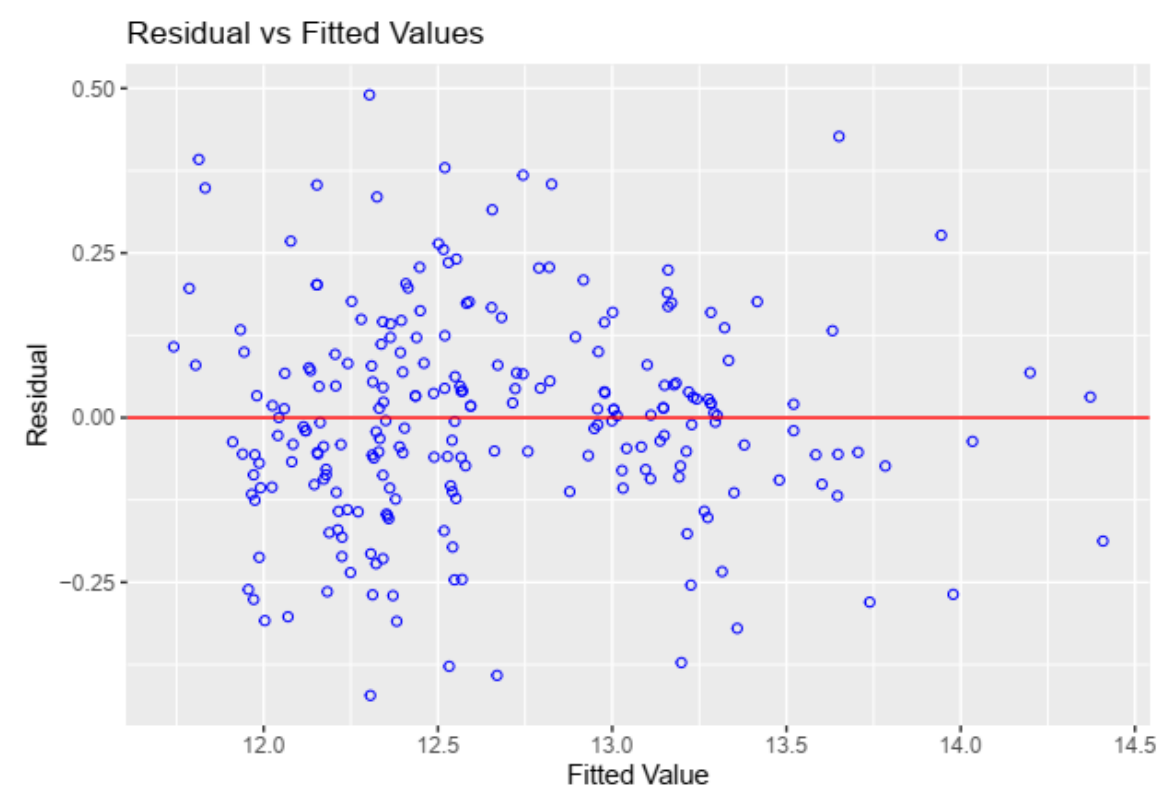

Figura 11- Gráfico dos resíduos padronizados versus valores ajustados do modelo 2. Fonte: Elaboração própria.

No gráfico dos valores ajustados versus resíduos (Figura 11), percebe-se uma melhor distribuição dos pontos indicando uma possível homogeneidade da variância, o que nos informa que a hipótese da homocedasticidade está sendo atendida para esse modelo. Da mesma forma que no Modelo 1, a homocedasticidade foi testada através do teste estatístico Breusch Pagan Test. A probablidade calculada foi de 0.2603998 , sendo maior que o nível de signifcância adotado de 5\%. Neste caso, a hipótese nula $\mathrm{H}_{0}$ é aceita e assume-se que o modelo tem uma variância constante, ou seja, a hipótese da homocedasticidade é aceita. 


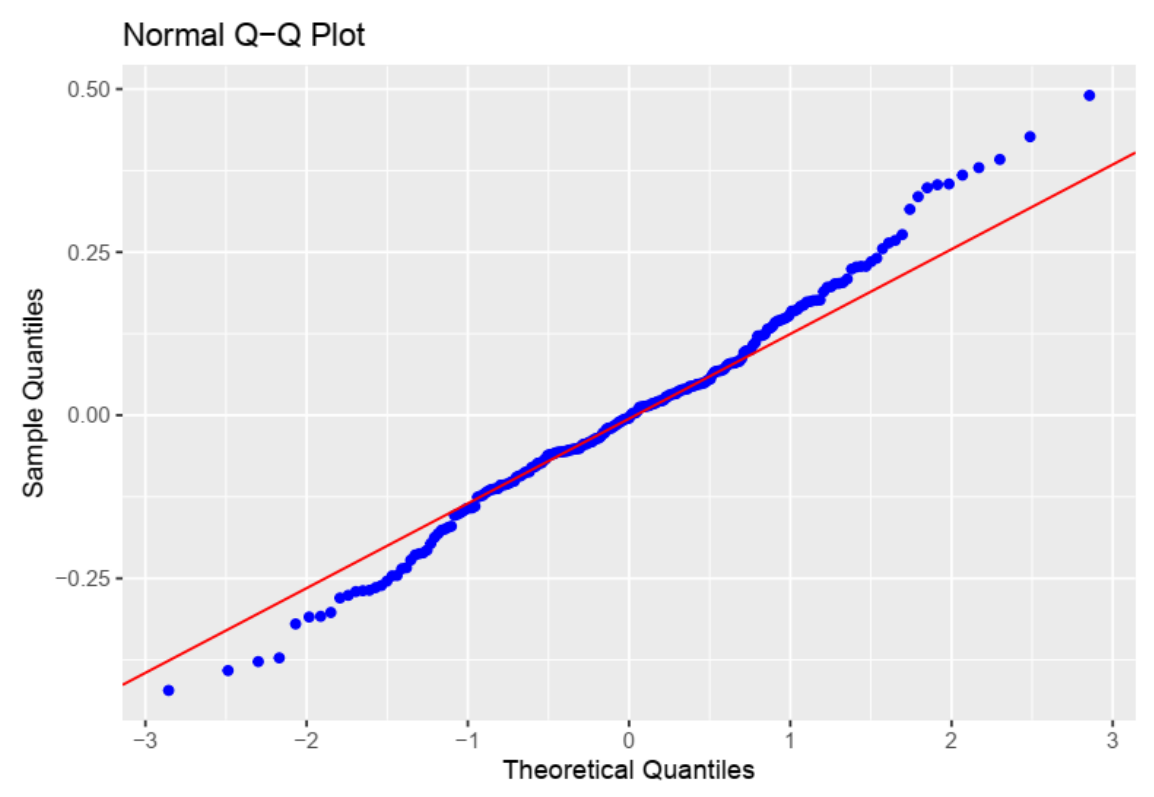

Figura 12- Gráfico Normal Q-Q plot do modelo 1. Fonte: Elaboração própria.

Para a hipótese da normalidade utilizou-se o gráfico Q-Q plot, que detecta o pressuposto de normalidade (Figura 12). Como se ver, os quantis da distribuição de probabilidade dos resíduos estão bem mais próximos da linha de normalidade que no modelo anterior mostrado. 0 que nos dar indícios da normalidade dos resíduos do modelo. Outra forma utilizada para detectação da normalidade dos resíduos foi através dos testes estatísticos mostrados anteriormente. Em dois dos testes (Shapiro-Wilk e Kolmogorov-Smirnov) vemos que o p-valor é maior que 0,05, aceitamos assim a hipótese nula de que os resíduos se comportam de forma normal. Para a hipótese de ausência de auto-correlação entre os resíduos utilizou-se o teste estatístico de Durbin-Watson. 0 resultado encontrado para a probabilidade p-valor foi de $9.025^{*} 10^{-7}$. 0 valor da estatística DW foi 1,3979, menor do que 2 , o que indica uma autocorrelação serial positiva dos resíduos. Neste caso, segundo Dantas (2013), a autocorrelação serial presente no modelo não é um problema para a estimação.

\subsection{DISCUSSÃO DOS RESULTADOS}

Uma forma de interpretar o modelo, segundo Dantas (2013), é torná-lo multiplicativo, aplicando assim o logaritmo natural a equação. Para isso, aplicou-se o exponencial nos dois lados da Equação 11 . 0 resultado obtido foi o seguinte: 


\section{VALOR $=5.767,53 *$ ÁREA0,89 * 1,05 * № SUÍTES * 1,20 * PADRÃO * 1,01 ANDAR * DIST. ÁREA PROTEGIDA- 0,12}

\section{Equação 11}

A partir da Equação 11, podemos tirar algumas conclusões com respeito à relação entre a variável de estudo, a distância à área protegida, com o mercado imobiliário em Campina Grande. Pela interpretação da equação, percebemos que quando a distância aumenta em 1\% o preço diminui em 0,12\%. Ou seja, a proximidade com a área protegida faz o valor do imóvel aumentar em 0,12\%. Percebe-se com isso, que existem evidências que comprovam uma valorização imobiliária causada pela existência da área protegida do estudo.

Ao traçar a curva de valor versus distância a partir da Equação 13, mantendose as outras variáveis fixas, percebe-se esta evidência de forma gráfica (Figura 13). Ademais, podemos fazer a análise da Figura 13 de forma semelhante a uma curva de demanda. Neste caso, para cada distância à área protegida de um imóvel, a Equação 13 nos informa qual deveria ser o valor daquele bem que os indivíduos escolhem para essa localização. Por exemplo: para morar em uma localização que fique a 3,5km da área verde os indivíduos em Campina Grande estão dispostos a pagar aproximadamente $\mathrm{R} \$ 300.000,00$, analisando pela curva azul. Quando o andar do apartamento aumenta, percebe-se que a curva azul sobe para a posição da curva vermelha. Isto nos informa que para a mesma localização, a 3,5km da área protegida, os indivíduos estão dispostos a pagar um valor de aproximadamente R \$ 315.000,00. Variação de valor em $\mathrm{R} \$ 15.000,00$ devido ao aumento de andar do apartamento.

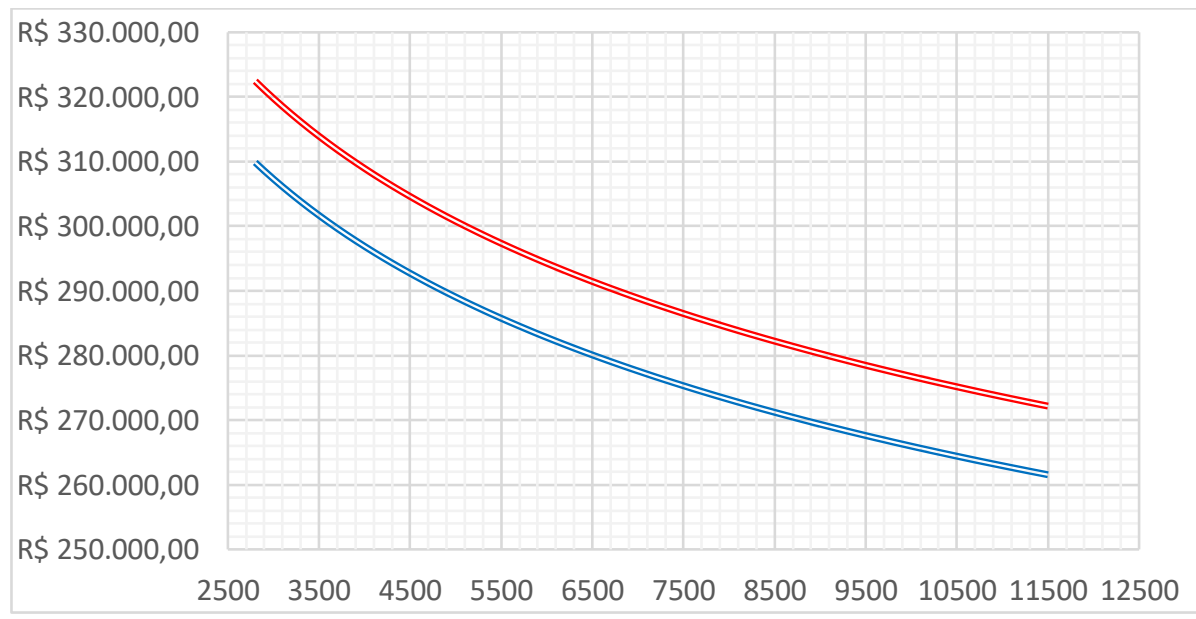

Figura 13- Gráfico de valor versus distância à área protegida. Fonte: Elaboração própria. 
Nesta perspectiva, podemos calcular também a disposição marginal a pagar que os agentes econômicos envolvidos no mercado imobiliário em Campina Grande possuem pela qualidade ambiental oferecida pela área protegida. Neste caso, vamos supor que estamos interessados em apartamentos de padrão normal (4) com área privativa de $100 \mathrm{~m}^{2}$, uma suíte e no sexto andar. Para isso, obtemos um valor constante, utilizando a Equação 11, de 803.216,07. Sendo assim, através da derivada primeira da função encontra-se a disposição marginal a pagar, que vai ser a taxa de variação para o aumento de $1 \mathrm{~m}$ na distância. Dessa forma, a Equação 11 assume a seguinte forma:

$$
D A P m=\frac{\delta \text { Valor }}{\delta \text { Dist }}=-96.385,93 \times \text { Dist. Área Protegida }{ }^{-1,12}
$$

Equação 12

O sinal negativo indica que o consumidor de apartamento em Campina Grande está disposto a substituir um valor monetário a mais pela moradia com maior qualidade ambiental, ou seja mais próxima (menos distância) à área protegida. Em módulo a Equação 12 também nos mostra que a disposição marginal a pagar diminui na medida em que o apartamento se distancia da área protegida (Figura 14). Ou seja, podemos afirmar que a proximidade com a área protegida faz com o que o benefício desta área seja percebido pelas pessoas de forma mais sensível. 0 que é totalmente razóavel afirmar, tendo em vista que alguém que mora mais próximo de uma área valorizada tem uma percepção maior dos benefícios desta localidade.

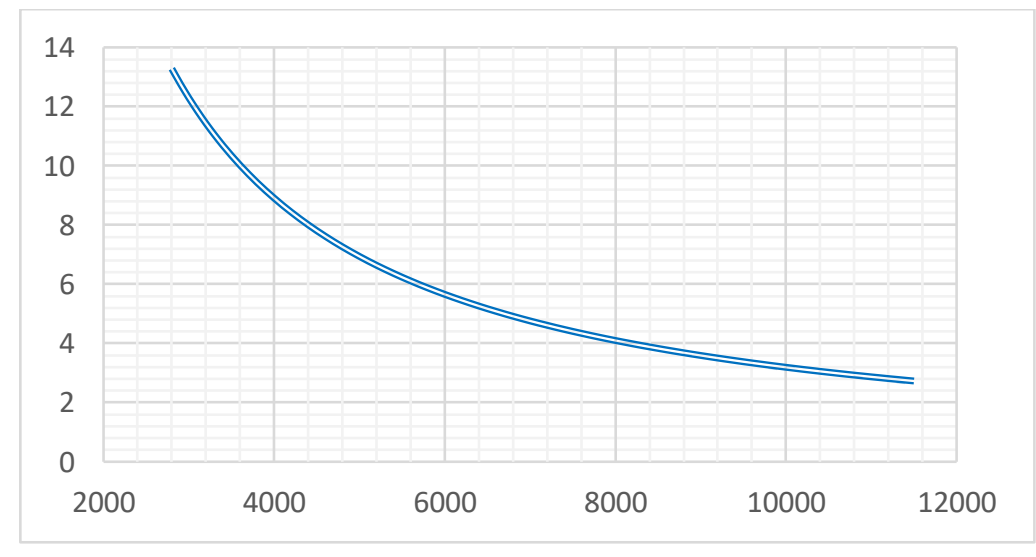

Figura 14- Disposição marginal a pagar versus distância à área protegida. Fonte: Elaboração própria. 
Os resultados encontrados diferem de algumas pesquisas que foram realizadas em outros locais no mundo como mostrado no Capítulo 4. Na pesquisa realizada por Luttik (2000) por exemplo, o efeito de uma paisagem atraente influenciou naquele período de tempo em 5 a 12 \%os valores dos imóveis, muito acima do que foi encontrado. Morancho (2003) estimou em sua pesquisa que na cidade de Castellón, na Espanha, quando o imóvel se distancia 100m de uma área verde o preço da habitação pode cair em 1800 euros. Para a cidade de Campina Grande, esta variação no valor do aumento em 100m de distância ao Parque do Poeta cai em aproximadamente 1000 reais (160 euros). Estas diferenças encontradas em outras cidades no mundo podem ter variadas causas, que vão desde influências em escala micro, como a estrutura do mercado imobiliário em Campina Grande, que contem poucos agentes de oferta, assim com o fato de uma parte da população local desconhecer a existência da área, até influências em escala macro, como a fragilidade institucional existente no Brasil que contribue para a degradação ambiental, como mostrado no estudo de Abman (2018) em que indica uma correlação positiva entre o estabelecimento da democracia, proteção dos direitos de propriedade e baixos níveis de corrupção com uma maior eficácia na governança das áreas protegidas. 


\section{CONCLUSÕES}

As áreas protegidas são um importante meio para a conservação dos sistemas ambientais e foram apresentadas no Capítulo 1 deste trabalho. Elas são usadas com esta finalidade desde o século XIX, mas só no século XX é que ficaram famosas, devido principalmente à influência de organizações internacionais como a IUCN, que até hoje apresenta-se como uma das principais organizações em defesa da proteção ambiental. A sua implantação de forma eficiente depende de inúmeros fatores que vão desde a cultura do povo, seu desenvolvimento sócio-econômico até a estabilidade política de uma nação. 0 conceito mais recente de área protegida desenvolvido pela instituição introduz o termo serviços ecossitêmicos como uma das funções dessas áreas. Esse conceito é fruto de um entendimento mais amplo que integra os sistemas ecológicos com o sistema sócio-econômico e foi usado como base na pesquisa.

No Brasil, as unidades de conservação se popularizaram a partir da criação do Sistema Nacional de Unidades de Conservação, chegando a um aumento exponencial na criação dessas áreas. Nesse sistema existem dois grandes grupos de UCs, as áreas de Proteção Integral e as de Uso Sustentável. A diferença principal desses grupos se dar no grau de alteração permitido no interior dessas áreas, em um é permitido certo nível de utilização de seus recursos e em outro não é permitido nenhuma utilização, entretanto, por mais que tenhamos um sistema legal estruturado não se tem garantia de que a principal finalidade dessas áreas são garantidas e essas unidades frequentemente tem enfrentado muitos problemas em todo o território nacional. 0 aumento do número dessas áreas não garantiu que os sistemas ecológicos sejam realmente protegidos. Neste sentido, o objeto do estudo em questão, o Parque do Poeta, inseriu-se nesse contexto.

Foram respondidos os objetivos do trabalho pelos métodos ciêntíficos mostrados, ressaltando a relevância desta área protegida na percepção do mercado imobiliário de apartamentos em Campina Grande, no qual incluem-se todas as pessoas que realizam transações envolvendo este tipo de bem e que em seu processo de escolha habitacional levam em consideração aspectos de qualidade ambiental, oferecido pelo Parque do Poeta. A partir dos resultados encontrados podemos observar possíveis causas da fragilidade institucional do Parque do Poeta, que 
mostram uma baixa adesão dos agentes envolvidos no mercado imobiliário, refletida no valor mensurado do parâmetro da variável de distância à área protegida. Este valor nos indica a percepção que existe sobre a importância de ter uma área verde protegida próxima de seu local de moradia. Na medida em que as pessoas envovidas neste mercado aumentam seu desejo em ter uma área verde com uma natureza preservada acessível perto delas ocorre uma variação positiva no valor do parâmetro, ou seja, o impacto desta área nos preços dos imóveis tende a crescer.

A pesquisa procurou entender a política de criação das áreas protegidas a partir de um recorte teórico escolhido, que foi o da teoria econômica ambiental. Neste sentido, foi feito uma revisão teórica dessa abordagem no Capítulo 2. Nem sempre é uma tarefa fácil entender as múltiplas inter-relações existentes entre as relações econômicas e o meio ambiente, para isso a criação de modelos é um importante instrumento para tal finalidade, mesmo diante de suas limitações. A observação dessas relações na teoria econômica ambiental é feita através do seu uso, que nos mostram certas características existentes sobre o fenômeno em estudo. Algumas teorias necessárias para essa tarefa foram trazidas neste capítulo, como a de externalidades e a de bens-públicos, assim como, contribuições da economia dos recursos naturais e críticas da economia ecológica para esta abordagem.

Neste sentido, o entendimento das externalidades para a pesquisa é crucial, tendo em vista que na maior parte dos casos as áreas protegidas são interpretadas como uma externalidade positiva, ou seja, os benefícios que elas proporcionam não são captados pelo sistema de preços nos mercados causando assim uma falha de mercado. 0 mercado imobiliário então foi usado como o meio para que possamos mensurar os benefícios proporcionados por estas áreas. Outra teoria revisitada, foi a de bem público. Estes benefícios que as áreas protegidas promovem, como os serviços ecossistêmicos, são sentidos por toda a sociedade de forma não-rival e nãoexclusiva, ou seja, as pessoas se beneficiam por um ar mais limpo promovido por essas áreas sem que outras pessoas possam ser privadas também desse benefício, bem como, é impossível impedir que as pessoas sejam limitadas a aproveitar os benefícios deste bem. Neste sentido, as áreas protegidas tanto podem promover estes benefícios a todos como é impossibilitado de impedir ou limitar que outras 
pessoas sejam beneficadas. Tendo em vista que, quando o ambiente natural está em equilíbrio as pessoas em sua proximidade se beneficiam como um todo.

No Capítulo 3 a questão do valor econômico do ambiente foi abordada. A necessidade de utilizar técnicas de valoração é sentida quando o agente público precisa aplicar os chamados Pagamento por Serviços Ambientais (PSA) para uma área protegida tendo em vista o financiamento de sua proteção. Para isso, o trabalho mensurou os benefícios do Parque do Poeta em termos monetários através de uma técnica indireta dos mesmos, o método de preços hedônicos (Capítulo 4). A impossibilidade de utilizar mecanismos de mercado para mensurar o valor de um bem público levou-nos a utilizar um bem complementar, o bem habitação, para a partir dele chegarmos ao valor da área protegida. Neste trabalho, o valor econômico da área protegida foi entendido como a disposição marginal a pagar pela qualidade ambiental, entendia como uma função da proximadade dos apartamentos com a área protegida. A disposição marginal a pagar foi calculada em relação à distância dos imóveis com o Parque do Poeta. A partir dela constatou-se que a variação da disposição a pagar por um ambiente natural em Campina Grande é maior quando se aproxima da área.

Por fim, o trabalho em questão procurou contribuir para a divulgação das áreas protegidas no Brasil e também para a ampliação das possibilidades de ações governamentais mais efetivas. A importância de conhecer a teoria econômica é importante quando o agente público vai tomar uma decisão que ocasionará mudanças nas relações de mercado. Por vezes estas ações que visam aumentar o bem-estar dos indivíduos podem gerar efeitos inesperados. Neste sentido, a aplicação de PSA precisa ser estudada em todos os seus aspectos e em seus possíveis impactos para a sociedade local. Tendo em vista que no Brasil já existe uma alta carga tributária e a implementação de novos tributos tende a ser mal vista pela população, mesmo que sejam justificadas como algo que realmente beneficia a todos. Esta pesquisa tentou trazer para este debate uma abordagem técnica da questão que visa legitimar a aplicação futura do PSA no Parque do Poeta. No mais, o trabalho limitou-se na fase preliminar da aplicação do PSA, a valoração econômica ambiental, e foi usado um aporte teórico metodológico específico, ficando em aberto para futuros trabalhos abordar possíveis formas de sua aplicação, assim como, o uso de outras metodologias que vão aprofundar o entendimento do fenômeno. 


\section{REEEREANCIAS BIBLIOGRÁFICAS}

ABMAN, Ryan. Rule of Law and Avoided Deforestation from Protected Areas. Ecological Economics, Amsterdam, v.146, p.282-289, 2018.

AGUIRRE, Antônio; DE FARIA, Diomira MCP. A Utilização de "preços hedônicos" na avaliação social de projetos. Revista Brasileira de Economia, v. 51, n. 3, p. 391-411, 1997.

AMAZONAS, Maurício de Carvalho. Valor ambiental em uma perspectiva heterodoxa institucional-ecológica. Economia e Sociedade, Campinas, v. 18, n. 1, p. 183212, 2009.

ANDAM, Kwaw S., et al. Measuring the Effectiveness of Protected Area Networks in Reducing Deforestation. Proceedings of the National Academy of Sciences of the United States of America, vol. 105, no. 42, 2008, pp. 16089-16094. JSTOR, www.jstor.org/stable/25465050. Accessed 22 Dec. 2020.

ANDRADE, Daniel Caixeta. Economia e meio ambiente: aspectos teóricos e metodológicos nas visões neoclássica e da economia ecológica. Leituras de economia política, v. 14, p. 1-31, 2008.

ANDRADE, Daniel Caixeta. Valoração econômico-ecológica: bases conceituais e metodológicas. São Paulo: Annablume, 2013.

ASSOCIAÇÃO BRASILEIRA DE NORMAS TÉCNICAS. NBR 14653: Avaliação de bens: Parte 6: Recursos Naturais e Ambientais. Rio de Janeiro: ABNT ,2008.

BELTRAME, Bruno; MATTOS, Laura Valladão de. As críticas de Amartya Sen à teoria da escolha social de Kenneth Arrow. Nova Economia, v. 27, n. 1, p. 65-88, 2017.

BAVEYE, Philippe C.; BAVEYE, Jacques; GOWDY, John. Monetary valuation of ecosystem services: it matters to get the timeline right. Ecological Economics, Amsterdam, v. 95, p. 231-235, 2013.

BELTRAME, Bruno; MATTOS, Laura Valladão de. As críticas de Amartya Sen à teoria da escolha social de Kenneth Arrow. Nova Economia, v. 27, n. 1, p. 65-88, 2017.

BHANDARI, Medani. International Union for Conservation of Nature. The WileyBlackwell Encyclopedia of Globalization, 2012.

BISHOP, Kelly C. et al. Best practices for using hedonic property value models to measure willingness to pay for environmental quality. Review of Environmental Economics and Policy, v. 14, n. 2, p. 260-281, 2020. 
BÖRGER, Tobias. The Economic Valuation of Environmental Goods. In: BÖRGER, Tobias. Social Desirability and Environmental Valuation. Frankfurt; Berlim; Berna; Bruxelas; New York; Oxford; Viena: Peter Lang AG, 2012.

BORRINI-FEYERABEND, Grazia et al. Governança de Áreas Protegidas: da compreensão à ação. UICN, Série Diretrizes para melhores Práticas para Áreas Protegidas, n. 20, 2017.

BRASIL. Lei no 9.985, de 18 de julho de 2000. Institui o Sistema Nacional de Unidades de Conservação da Natureza e dá outras providências. Brasília, 2000.

BROCKINGTON, Daniel, and James Igoe. Eviction for Conservation: A Global Overview. Conservation and Society, vol. 4, no. 3, 2006, pp. 424-470. JSTOR, www.jstor.org/stable/26396619. Accessed 22 Dec. 2020.

CALLAN, Scott J.; THOMAS, Janet M. Environmental economics and management: Theory, policy, and applications. Cengage learning, 2013.

CASIMIRO FILHO, Francisco. Valores monetários de amenidades ambientais: algumas considerações. 1999.

CORSON, Catherine; GRUBY Rebecca, WITTER, Rebecca; HAGERMAN, Shannon; SUAREZ, Daniel; GREENBERG, Shannon; BOURQUE, Maggie; GRAYH, Noella; CAMPBELL, Lisa M.. Everyone's Solution? Defining and Redefining Protected Areas at the Convention on Biological Diversity. Conservation and Society, v.12, n. 2, p. 190-202, 2014.

COSTANZA, Robert et al. The value of the world's ecosystem services and natural capital. Nature, v. 387, n. 6630, p. 253-260, 1997.

DA VEIGA, José Eli. Desenvolvimento sustentável: o desafio do século XXI. Rio de Janeiro: Editora Garamond, 2005.

DALY, Herman E.; FARLEY, Joshua. Ecological Economics: Principles and Applications. 5aed. Washington: Island Press, 2004.

DANTAS, Rubens Alves. Modelos espaciais aplicadas ao mercado habitacional um estudo de caso para cidade do Recife. Tese (Doutorado em Ciências Econômicas) - Universidade Federal de Pernambuco, 2003. Disponível em: <https://repositorio.ufpe.br/handle/123456789/3833>. Acesso em: agosto de 2020 .

DANTAS, Rubens Alves. Engenharia de Avaliações: uma introdução à metodologia científica. Pini, 2012.

DE AGUIAR, Carolina Costa; TRENTINI, Flavia. Externalidades positivas e custos dos espaços protegidos em áreas de produção sucroenergética. Revista da AMDE, v. 7, p. 134-185, 2012. 
DE SOUSA RAMOS, Francisco. Qualidade do meio-ambiente e falhas de mercado. Análise Econômica, v. 14, n. 25 e 26, 1996.

DE SOUSA SANTARLACCI, Angelo et al. Externalidades positivas geradas pelo parque olhos d'água ao mercado imobiliário de Brasília (DF) por meio de índices hedônicos. Natural Resources, v. 9, n. 2, p. 36-42, 2019.

DIXON, John A. ; SHERMAN, Paul B. Economics of Protected Areas. Ambio, vol. 20, no. 2, 1991, pp. 68-74. Disponível em: www.jstor.org/stable/4313779.

DO CARMO, Ricardo Santos; ALCOFORADO, Ihering Guedes. RACIONALIDADE: 0 ELO ENTRE A ECONOMIA E A BIOLOGIA DA CONSERVAÇÃO.

Duranton, Gilles, and Diego Puga. The Economics of Urban Density. The Journal of Economic Perspectives, vol. 34, no. 3, 2020, pp. 3-26. JSTOR, www.jstor.org/stable/26923539. Accessed 15 Jan. 2021.

ERVIN, Jamison. Protected Area Assessments in Perspective. BioScience, vol. 53, no. 9, 2003, pp. 819-822. JSTOR, www.jstor.org/stable/10.1641/00063568(2003)053[0819:paaip]2.0.co;2. Accessed 22 Dec. 2020.

FARIA, Pedro Duarte; PARGA, João Pedro Figueira Amorim. Introdução à Linguagem R. 2020.

FÉLIX, Augusto César Trigueiro; FONTGALLAND, Isabel Lausanne. Custos Econômicos da Diminuição dos Serviços Ecossistêmicos nas Unidades de Conservação da Amazônia. Revista Ibero-Americana de Ciências Ambientais, v. 12, n. 2, 2021.

FENKER, Eloy Antonio. A valoração econômica dos recursos naturais na criação de unidades de conservação federais (UCF) no Brasil: Um estudo empírico no estado de Santa Catarina. Tese (Doutorado em Administração) - Universidade do Vale do Itajaí, Biguaçu, 2013. Disponível em: $\quad$ <http://siaibib01.univali.br/pdf/Eloy\%20Antonio\%20Fenker.pdf>. Acesso em: agosto de 2020.

FIELD, Barry C.; FIELD, Martha K. Environmental economics an introduction. 6 ed. Nova York: The McGraw-Hill, 2017.

FRANCO, José Luiz de Andrade; SCHITTINI, Gilberto de Menezes; BRAZ, Vivian da Silva. História da conservação da natureza e das áreas protegidas: panorama geral. Historae, Rio Grande, v.6, n.2, 2015.

FREIRE, Neison Cabral Ferreira et al. Mapeamento e análise espectro-temporal das unidades de conservação de proteção integral da administração federal no bioma caatinga. Brazilian Journal of Development, São José dos Pinhais, v. 6, n. $5,2020$. 
FRÖR, Oliver. Rationality concepts in environmental valuation. Berlin: Peter Lang International Academic Publishers, 2007.

FURTADO, Bernardo Alves. Economia urbana e modelos hedônicos: especificidades e ilustração. 2011.

GAMARRA, Norah Costa et al. Are protected areas undervalued? An asset-based analysis of Brazilian protected area management plans. Journal of environmental management, v. 249, p. 109347, 2019.

GEORGESCU-ROEGEN, Nicholas. The entropy law and the economic process. Harvard University Press, 1971.

GUJARATI, Damodar; PORTER, Dawn C. Econometria Básica. Ed. Campus/Elsevier, 2006.

HANLEY, Nick; SHOGREN, Jason F.; WHITE, Ben. Environmental economics: in theory and practice. Macmillan International Higher Education, 2016.

HANNAH, Lee, et al. Protected Area Needs in a Changing Climate. Frontiers in Ecology and the Environment, vol. 5, no. 3, 2007, pp. 131-138. JSTOR, www.jstor.org/stable/20440608. Accessed 22 Dec. 2020.

HARRIS, Jonathan M.; ROACH, Brian. Environmental and natural resource economics: A contemporary approach. ME Sharpe, 2013.

HERMANN, Bruno M.; HADDAD, Eduardo A. Mercado imobiliário e amenidades urbanas: a view through the window. Estudos Econômicos (São Paulo), v. 35 , n. 2, p. 237-269, 2005.

HERMANN, Bruno Martins. Estimando o preço implícito de amenidades urbanas: evidências para o município de São Paulo. 2003. Tese de Doutorado. Universidade de São Paulo.

HIDANO, Noboru. The economic valuation of the environment and public policy: a hedonic approach. Edward Elgar Publishing, 2002.

HUSSEN, Ahmed M. Principles of environmental economics. Psychology Press, 2004.

KANEMOTO, Yoshitsugu. Theories of urban externalities. 1980.

JOHANNESEN, Anne Borge. Protected areas, wildlife conservation, and local welfare. Ecological Economics, Amsterdam, v.62, 2007.

KUMINOFF, Nicolai V.; SMITH, V. Kerry; TIMMINS, Christopher. The new economics of equilibrium sorting and policy evaluation using housing markets. Journal of economic literature, v. 51, n. 4, p. 1007-62, 2013. 
LANCASTER, Kelvin J. A new approach to consumer theory. Journal of political economy, v. 74, n. 2, p. 132-157, 1966.

LANG SILVEIRA, Fernando. A metodologia dos programas de pesquisa: a epistemologia de Imre Lakatos. Caderno catarinense de ensino de fisica. Florianópolis. Vol. 13, n. 3, p. 219-230, 1996.

LEBERGER, Roxanne; ROSA, Isabel MD; GUERRA, Carlos A.; WOLF, Florian; PEREIRA, Henrique M. Global patterns of forest loss across IUCN categories of protected areas. Biological Conservation, v.241, 2020.

LELE, Sharachchandra, et al. Ecosystem Services: Origins, Contributions, Pitfalls, and Alternatives. Conservation and Society, vol. 11, no. 4, 2013, pp. 343-358. JSTOR, www.jstor.org/stable/26393131. Accessed 22 Dec. 2020.

LIU, Tian et al. Exploring spillover effects of ecological lands: A spatial multilevel hedonic price model of the housing market in Wuhan, China. Ecological Economics, v. 170, p. 106568, 2020.

LUTTIK, Joke. The value of trees, water and open space as reflected by house prices in the Netherlands. Landscape and urban planning, v. 48, n. 3-4, p. 161-167, 2000.

MARTIN, Laura J., and Bernd Blossey. A Framework for Ecosystem Services Valuation. Conservation Biology, vol. 23, no. 2, 2009, pp. 494-496. JSTOR, www.jstor.org/stable/29738751. Accessed 22 Dec. 2020.

MERCADANTE, Maurício. Uma Década de Debate e Negociação: a História da Elaboração da Lei do SNUC. In: BENJAMIN, Antônio Herman (Coordenador). Direito Ambiental das Áreas Protegidas. Rio de Janeiro: Forense, 2001.

MILARÉ, Edis. Direito do Ambiente: a gestão ambiental em foco: doutrina, jurisprudência, glossário.7.ed. rev. São Paulo: Editora Revista dos Tribunais, 2011.

MINISTÉRIO DO MEIO AMBIENTE (MMA). Convenção sobre Diversidade Biológica - CDB. Brasília, 2000b. Disponível em: https://www.mma.gov.br/estruturas/sbf_dpg/_arquivos/cdbport.pdf. Acesso em: agosto de 2020.

MORANCHO, Aurelia Bengochea. A hedonic valuation of urban green areas. Landscape and urban planning, v. 66, n. 1, p. 35-41, 2003.

MOREIRA DE AGUIAR, Marina; SIMÕES, Rodrigo; BRAZ GOLGHER, André. Housing market analysis using a hierarchical-spatial approach: the case of Belo Horizonte, Minas Gerais, Brazil. Regional Studies, Regional Science, v. 1, n. 1, p. 116-137, 2014.

MOTTA, R.S. Economia ambiental. Rio de Janeiro: FGV Editora, 2006. 
MOTTA, R.S. Manual para valoração econômica de recursos ambientais. Rio de Janeiro: IPEA/MMA/PNUD/CNPq, 1997.

MUELLER, Charles C. Economia e meio ambiente na perspectiva do mundo industrializado: uma avaliação da economia ambiental neoclássica. Estudos Econômicos (São Paulo), v. 26, n. 2, p. 261-304, 1996.

MUNASINGHE, Mohan. Environmental economics and sustainable development. The World Bank, 1993.

NADALIN, Vanessa G. Economia urbana e mercado de habitação. Economia regional e urbana, p. 221, 2011.

NETO, Afonso Negri. Preços hedônicos. Economics, v. 58, n. 3, p. 504-510, 1976.

Pearson, K. 1920. Notes on the History of Correlation. Biometrika 13 (1): 2545. https://doi.org/10.2307/2331722.

NORDHAUS, William D. A question of balance: Weighing the options on global warming policies. Yale University Press, 201

NURMI, Väinö; AHTIAINEN, Heini. Distributional weights in environmental valuation and cost-benefit analysis:theory and practice. Ecological economics, Amsterdam, v.150,p. 217-228, 2018.

PEARCE, David. An intellectual history of environmental economics. Annual review of energy and the environment, v. 27, n. 1, p. 57-81, 2002.

PEREIRA, Heloísa Corrêa. Distribuição e mobilidade espacial da população em unidades de conservação de uso sustentável na Amazônia brasileira: o caso da reserva extrativista Auati-Paraná. Tese (Doutorado) Universidade Estadual de Campinas, Instituto de Filosofia e Ciências Humanas, 2017.

PEREIRA, Polyana Faria; SCARDUA, Fernando Paiva. Espaços territoriais especialmente protegidos: conceito e implicações jurídicas. Ambiente \& Sociedade, Campinas, v. 11, n. 1, p. 81-97, 2008.

PERMAN, Roger; MA, Yue; MCGILVRAY, James; COMMON, Michael. Natural resource and environmental economics. Pearson Education, 2003.

PROGRAMA DAS NAÇÕES UNIDAS PARA O MEIO AMBIENTE. Declaração da Conferência das Nações Unidas sobre o Meio Ambiente Humano: Declaração de Estocolmo, 1972. Disponível em: <https://apambiente.pt/_zdata/Politicas/DesenvolvimentoSustentavel/19 72_Declaracao_Estocolmo.pdf>. Acesso em agosto de 2020.

PUREZA, Fabiana. Unidades de conservação. Belo Horizonte: Matrix Editora, 2016. 
QUEIROZ, Claudia Nascimento; BORTOLUZI, C. Roque Dallajustina. Os Economistas, O Meio Ambiente e a Gestão dos Recursos Naturais: Em Busca do Diálogo entre Distintas Abordagens. In: BARBOSA, Erivaldo Moreira; BATISTA, Rogaciano Cirilo; BARBOSA, Maria de Fátima Nóbrega. Gestão dos recursos naturais: uma visão multidisciplinar. Rio de Janeiro: Ed. Ciência Moderna Ltda., 2012.

ROSEN, Sherwin. Hedonic prices and implicit markets: product differentiation in pure competition. Journal of political economy, v. 82, n. 1, p. 34-55, 1974.

ROSSI-HANSBERG, Esteban, et al. Housing Externalities. Journal of Political Economy, vol. 118, no. 3, 2010, pp. 485-535. JSTOR, www.jstor.org/stable/10.1086/653138. Accessed 15 Jan. 2021.

SALOMÃO, Ana Luísa Fagundes. Florestas Nacionais no Brasil: Contradições e desafios do Conceito de Uso Múltiplo dos Recursos Naturais. In: CONGRESSO BRASILEIRO DE UNIDADES DE CONSERVAÇÃO, 1, 1997, Curitiba. Florestas Nacionais no Brasil: Contradições e desafios do Conceito de Uso Múltiplo dos Recursos Naturais. Curitiba: IAP: UNILIVRE: 1997. p. 403-413.

SAMUELSON, Paul Anthony; NORDHAUS, William D. Economia. 17 ed. 2004.

SANDMO, Agnar. The early history of environmental economics. Review of Environmental Economics and Policy, v. 9, n. 1, p. 43-63, 2015.

SANTOS, Sara Alves. As unidades de conservação no cerrado frente ao processo de conversão. Dissertação (Mestrado em Geografia) - Universidade Federal de Goiás, Instituto de Estudos Socioambientais, Goiânia, 2018.

SAPHORES, Jean-Daniel; LI, Wei. Estimating the value of urban green areas: A hedonic pricing analysis of the single-family housing market in Los Angeles, CA. Landscape and urban planning, v. 104, n. 3-4, p. 373-387, 2012.

SCHAERER, Caroline et al. Using the hedonic approach to value natural land uses in an urban area: An application to Geneva and Zurich. Économie publique/Public economics, n. 20, 2008.

SCHERL, Lea M. et al. As áreas protegidas podem contribuir para a redução da pobreza: Oportunidades e limitações. Reino Unido: IUCN, p. 60, 2006.

SEABRA, Deborah Maria da Silva; NETO, Raul da Mota Silveira; DE MENEZES, Tatiane Almeida. Amenidades urbanas e valor das residências: uma análise empírica para a cidade do Recife. Economia Aplicada, v. 20, n. 1, p. 143-169, 2016.

SILVA, Anelise Gomes da. Valoração econômica ambiental em unidades de conservação: um panorama do contexto brasileiro. Dissertação (Mestrado em Engenharia Ambiental). Escola de Engenharia de São Carlos da Universidade de São Paulo, São Carlos, 2015. 
SIMPSON, R. DAVID. Putting a Price on Ecosystem Services. Issues in Science and Technology, vol. 32, no. 4, 2016, pp. 57-62. JSTOR, www.jstor.org/stable/24727092. Accessed 22 Dec. 2020.

SOUZA, Alexsandro Silva; DE LIMA, Valéria Raquel Porto. Conflitos de uso e ameaças a paisagem da Unidade de Conservação Parque Estadual do Poeta e Repentista Juvenal de Oliveira, Campina Grande-PB: uma proposta de intervenção. Revista de Geociências do Nordeste, Natal, v. 4, 2018.

TAYLOR, Laura O. The hedonic method. In: A primer on nonmarket valuation. Springer, Dordrecht, 2003. p. 331-393.

TAYLOR, Laura O. Theoretical foundations and empirical developments in hedonic modeling. In:Hedonic methods in housing markets. Springer, New York, NY,2008. p.15-37.

TIETENBERG, Thomas H.; LEWIS, Lynne. Environmental and natural resource economics. Routledge, 2018.

TOFETI, Alexandre Resende. As transformações nos usos do território promovidas pelas unidades de conservação no Brasil. Tese (Doutorado em Geografia) - Universidade de Brasília, Departamento de Geografia, Brasília, 2018.

VALLADARES NETO, José et al. Boxplot: um recurso gráfico para a análise e interpretação de dados quantitativos. Revista Odontológica do Brasil Central, v. 26, n. 76, 2017.

VALLEJO, Luiz Renato. Unidade de conservação: uma discussão teórica à luz dos conceitos de território e políticas públicas. 2009

VERBEEK, M. A Guide to Modern Econometrics. Editora Wiley, 2012

WALDE, Janette F., et al. A Protected Area between Subsistence and Development. International Journal of the Commons, vol. 13, no. 1, 2019, pp. 175-204. JSTOR, www.jstor.org/stable/26632718. Accessed 22 Dec. 2020.

WARDROPPER, C. B. et al. Ecological worldview, agricultural or natural resourcebased activities, and geography affect perceived importance of ecosystem services. Landscape and Urban Planning, v. 197, p. 103768, 2020. 


\section{VALORAÇÃO ECONÔMICA AMBIENTAL DE ÁREA PROTEGIDA EM CAMPINA GRANDE-PB}

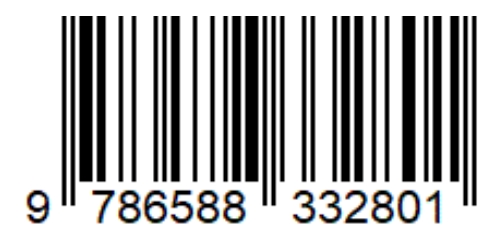

